\title{
SOME PHYSIOLOGICAI, AND BIOCHEMICAL ASPECTS \\ OF CHILLING INJURY OF GRAFEFRUIT (Citrus paradisi Macf.) WITH EMPHASIS ON GROWTH REGULATORS
}

By

KAZUHIDE KAWADA

A DISSERTATION PRESEITED TO THE GRADUATE COUNCIL OF THE UNIVERSTTY OF F'LORIDA

IN PARTIAL FULFILLMEIT OF THE RESUIRAMENTS FOR THE DEGREE OF IOCTOR OE PHILOSOPHY

UNIVERSITY OF FIORIDA 
To my family and friends, whose constant encouragement and love made it all possible. 


\section{ACKNOWLEDGMENTS}

The author expresses his sincere gratitude to Dr. James Soule, Chairman of the Supervisory Committee, for his invaluable guidance, encouragement, and editorial advice during the preparation of this dissertation. The author is particularly indebted to Dr. William Grierson, Co-chairman of the Supervisory Committee, for suggesting the research problems, his close and continuous supervision and encouragement throughout this study, and much time and discussion devoted to assistance with preparation of this manuscript.

Deep acknowledgment is expressed to Dr. T. Adair Wheaton for his technical and personal counsel in completing this study. Special appreciation is also owed to Dr. Mohamed A. Ismail for constructive criticism and Dr. Thomas E. Humphreys for literary advice throughout the program.

The author is also greatly thankful to Dr. Hassan M. Ali-Dinar, Mr. James W. Rushing, Mrs. Jane Van Clief, Mr. Perry D. Cooper and Mr. Paul Rebenack for their indispensable help and friendship. Sincere thanks go to Mrs. Peggy Lee and Mrs. Brenda Hollis for typing the manuscript. 
Financial assistance provided by sea-Land Service, Inc. and Fairfield-Maxwell Ltd. is greatly appreciated. Finally, the unlimited support and encouragement of the author's advisors in Japan, Drs. Hirotoshi Kitagawa and Masaharu Taniguchi, are acknowledged with gratitude. 
TABLE OF CONTENTS

page

ACKNOWLEDGMENTS....................... ii

ABSTRACT. . . . . . . . . . . . . . .

I. INTRODUCTION $\ldots \ldots \ldots \ldots \ldots \ldots \ldots \ldots \ldots \ldots \ldots \ldots$

II. SEPARATION AND IDENTIFICATION OF ENDOGENOUS GROWTH REGULATORS IN GRAPEFRUIT FLAVEDO BY

HIGH-PERFORMANCE LIQUID CHROMATOGRAPHY...... 5

Literature Review................ 5

Materials and Methods................. 14

Results and Discussion............... 16

III. SEASONAL CHANGES IN RESISTANCE TO CHILLING INJURY AND ENDOGENOUS GROWTH REGULATOR LEVELS

IN FLORIDA 'MARSH' GRAPEFRUIT FLAVEDO........ 19

Literature Review................ 19

Materials and Methods................ 46

Results and Discussion.............. 47

IV. RFFECTS OF CONDITIONING TREATMENTS ON

SEASONAL RESISTANCE TO CHILLING INJURY AND

ON ENDOGENOUS GROWTH REGULATOR LEVELS IN

FLORIDA 'MARSH' GRAPEFRUIT FLAVEDO........ 56

Literature Review................ 56

Materials and Methods................. 66

Results and Discussion............. 67

V. GENERAL DISCUSSION................. 74

Parallel variations............... 74

Excision of Hormonal Source...................... 76

Substitution by Exogenous Hormone...... 76

Isolation of System.............. 76

Generality in Different Plants......... 76

Specificity of Hormone............ 77

vi. Conclusions....................... 78

LITERATURE CITED..................... 98

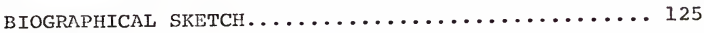




\section{Abstract of Dissertation Presented to the Graduate Council of the University of Florida in Partial Fulfillment of the Requirements for the Degree of Doctor of Philosophy}

SOME PHYSIOLOGICAL AND BIOCHEMICAL ASPECTS

OF CHILIING INJURY OF GRAPEFRUIT (Citrus paradisi Macf.) WITH EMPHASIS ON GROWTH REGULATORS

\section{By}

\section{KAZUHIDE KAWADA}

December 1980

Chairman: Dr. James Soule

Co-chairman: Dr. William Grieson

Major Department: Horticultural Science (Fruit Crops)

Resistance to chilling injury (CI) of Florida grape-

fruit has been found to be seasonal, being most resistant in midseason, and a hypothesis that growth regulators (GRs) are involved in resistance to $C I$ was proposed. The relationship between resistance to $C I$ and levels of endogenous GRs in the flavedo of 'Marsh' grapefruit was studied to test the hypothesis.

A useful, reliable and precise high-performance liquid chromatographic method, coupled with isotope dilution, was developed for routine quantitative analyses of GRs. Resistance to CI and levels of endogenous indoleacetic (IAA) and abscisic (ABA) acids were determined for fruit samples harvested biweekly or after 3-day conditioning (delayed storage) treatments under several conditions. 
Immature grapefruit harvested in August were more resistant to CI than fruit harvested in october. Conditioned grapefruit clearly showed the existence of midseason resistance to $\mathrm{CI}$, but this was not apparent for fruit stored immediately after harvest. Seasonal changes in CI resistance of conditioned fruit were negatively correlated with mean minimum temperatures for the 30 days preceding harvests.

Conditioning markedly increased CI resistance in all 3 seasons (1977-78 to 1979-80). Experiments in 1978-79 showed a clear second degree polynomial correlation between CI resistance and prestorage weight loss due to conditioning treatments. Maximum resistance occurred with about 3\% weight loss. However, subsequent experiments showed that a conditioning treatment resulting in no weight loss also increased $\mathrm{CI}$ resistance, indicating that time delay per se may be important. There was no additional increase in CI resistance from adaing $5 \mathrm{ppm}$ ethylene during 3-day conditioning at $29^{\circ} \mathrm{C}$ and $90+\%$ relative humidity.

Levels of IAA in the flavedo remained relatively constant throughout $1977-78$ and $1978-79$ at about $10 \mathrm{ng} / \mathrm{g}$ fresh weight. Distinct searonal changes were observed in both free and bound $A B A$ levels. Bound $A B A$ in both seasons and free $A B A$ in 1977-78 exhibited only one midseason peak, but free $A B A$ in 1978-79 had 3 peaks in midseason. Free $\mathrm{ABA}$ ranged from 20 to $850 \mathrm{ng} / \mathrm{g}$ fresh weight and bound $\mathrm{ABA}$ 
from 100 to as much as $9,000 \mathrm{ng} / \mathrm{g}$ fresh weight. Generally high $A B A$ levels in the midseason periods were associated with mean mininum field temperatures for the 30 days preceding harvests. Free ABA increased rapidly from 100 to $500 \mathrm{ng} / \mathrm{g}$ fresh weight soon after freezing weather in March, 1980. Conditioning treatments increased free $A B A$ levels, the maximum occurring with a treatment that caused about $2 \%$ weight loss. Ethylene at 5 ppm during conditioning increased bound $A B A$ much more than free $A B A$.

Parallel variations occurred between midseason resistance to $\mathrm{CI}$ of conditioned grapefruit and levels of $\mathrm{ABA}$ at harvest. Conditioning-induced resistance to $\mathrm{CI}$ was also positively correlated with increased levels of $A B A$. Immature grapefruit, nevertheless, were resistant to $C I$ even when levels of $A B A$ were low, and addition of ethylene during conditioning increased $\mathrm{ABA}$ content but did not increase CI resistance.

This study provided some confirmation of the original hypothesis that resistance to CI involves endogenous GRs, with implication of some role for $\mathrm{ABA}$. The manner of action of such a relationship remains unclear. 
Chilling injury (CI) is a physiological disorder of certain plants, generally those of tropical and subtropical origin, or parts thereof, resulting from exposure to low but nonfreezing temperatures. This terminology is based on Molisch's suggestion in 1896 (175) that low temperature damage in the absence of freezing should be called CI ("Erkältung") as opposed to freezing injury ("Erfieren") . Preharvest CI limits geographic distribution and productivity of CI-sensitive plants, and postharvest CI limits use of low temperature to prolong shelf-life or extend the marketing area of many important horticultural crops. The latter problem becomes particularly acute in mixed shiploads of commodities having different optimum storage temperatures. Symptoms of this disorder include surface pitting and scald, internal browning and breakdown, increased susceptibility to decay, and in some fruits, failure to ripen. Specific information on various horticultural crops is given in Lutz and Hardenburg (155), on tomato, pepper and eggplant in McColloch et al. (164), and on citrus and other subtropical fruits in smoot et al. (235). There are a number of excellent reviews on the physiological bases of CI $(35,86,147,156,157,189)$, and several doctoral dissertations $(62,113,148,240$, 
271, 276), including 2 on Florida grapefruit (Citrus paradisi Macf.) (188, 253).

Grapefruit originated in the West Indies, unlike other members of the citrus subfamily (Aurantioideae) which are native to subtropical and tropical Asia (231), and is ore of the most CI susceptible fruits (155). Ramsey (199) noted serious spotting on grapefruit in cold storage as early as 1915. Brooks and McColloch (27) and van der Plank (257) gave good descriptions of CI with several pictures, which include pitting or "pox," brown staining or scald, oil-gland darkening, and soggy or watery breakdown. Many landmark studies on CI were published in the 1920s and 30s, particularly in 1936, which are still remarkably pertinent from physiological points of view and which merit reevaluation. Such old literature was thoroughly reviewed by Miller (172) and by Rose et al. (214). Recent reports on CI, mainly from Floriaa, have been reviewed by Grierson and Hatton (87). Susceptibility of grapefruit is known to be influenced by soil type (172), variety (102, 188, 257), fertilization (13, 71, 92), climate $(132,218,235)$, fruit maturity and harvesting season (87, 94), position on tree (188, 258) and size of rruit (235) and is also known to vary from tree to tree (94). But, physiological reasons for such differences are not yet understood. 
Chilling injury sharply limits the degree to which refrigeration can retard both physiological senescence and fungal invasion; thus CI has been recognized as a major limiting factor in both long-term storage (27) and export (188). In recent years, this problem has become more important to the Florida citrus industry (which produces more than half of the world's grapefruit) because of 1) expanded exports, currently largely to Japan $(70$ to $80 \%$ of the total Florida grapefruit exports), which take a 4 week voyage plus 2 weeks or more post voyage to reach consumers there; 2) the possibility that cold sterilization of fruit fly larvae at $0^{\circ} \mathrm{C}$ for 2 weeks nay be required for shipments to Japan and several states in the U.S. if the U.S. Environmental Protection Agency bans use of ethylene dibromide for fruit fumigation, as is currentlY proposed (65); and 3) predicted sharp increase in production (68) which would require longterm storage to expand the shipping season through the summer months. The need to expand shipments is, however, during a period when, according to Grierson (85), the fruit again becomes very susceptible to CI after the midseason resistant period. The hypothesis was proposed that susceptibility and resistance to $C I$ might be under growth regulator (GR) control (85). Subsequent experiments with both pre- and postharvest applications of several GRs did, indeed, modify susceptibility of grapefruit to CI (118). 
Recent reports $(207,209,211)$ on manipulating resistance to $C I$ in cucumber seedlings with abscisic acid (ABA) also support this hypothesis. Apparently no studies have been undertaken to link endogenous GR levels and CI and there are no reports at all on seasonal changes in levels of endogenous GRs in grapefruit throughout a season. It has also been suggested that the sensitivity of grapefruit to CI might involve either peel pigments or the plastids containing them (85). Certain postharvest, prestorage treatments, such as "delayed storage," "curing," and "conditioning," are known to enhance resistance of grapefruit to CI $(27,51,156,172,256)$, but mechanisms of such effects are not yet known.

The principal objectives of this research were to test Grierson's hypothesis that GRs control CI, and to do so in 2 steps: 1) determine quantitative changes in some endogenous GRs in the flavedo of 'Marsh' grapefruit harvested biweekly throughout several seasons, while monitoring seasonal changes in peel color and grove temperatures as well as resistance to CI (Chapter III); and 2) study effects of several delayed storage treatments on endogenous GR levels and on resistance of 'Marsh' grapefruit to CI (Chapter IV). Prior to accomplishing these objectives, improved methodology for separating and identifying GRs by high-performance liquid chromatography was, developed (Chapter II). Results are generally discussed (Chapter V) and conclusions drawn (Chapter VI). 


\section{CHAPTER II \\ SEPARATION AND IDENTIFICATION OF ENDOGENOUS \\ GROWTH REGULATORS IN GRAPEFRUIT FLAVEDO \\ BY HIGI-DERFORMANCE LIQUID CHROMATOGRAPHY}

\section{Literature Review}

\section{Quantitative Analysis of plant Growth Regulators}

Development of suitable analytical methods has given considerable impetus to the study of endogenous growth regulators (GRs). The discovery and first quantitative assay of auxin was due to Went's Avena curvature test developed about 50 years after the Darwins showed phototropic curvature of coleoptiles in 1880 (248). The introduction of gas chromatography (GC) as a tool for ethylene analysis strongly stimulated research in this area $(4$, p. 8). Much of the research on GRs in the last several years would not have been possible without newer and increasingly sophisticated analytical techniques, such as GC-mass spectrometry (GC-MS) and high-performance liquid chromatography (HPLC). Powell discussed this evolution of plant hormone analytical techniques in a 1972 review (195) and wheaton and Bausher did so in 1977 (277). There are a number ff excellent book chapters on analysis of GRs (e.g., 4, 248, 272). Mitchell and Livingstone's handbook (174) and Steffens' review (238) 
are excellent sources for bioassays. Hillman's (104) textbook is devoted to modern methods of isolation and physicochemical quantification of plant GRs. Moreover, these techniques have improved significantly since the book was published in 1978 .

Sampling

Lack of attention to sampling methods can obscure the physiological significance of GRs. Dennis (54) pointed out the possibility " . . on a concentration basis, one portion may contain considerably higher levels of the hormone than another. If the tissues are pooled in extraction, such differences will be overlooked" (p. 217). Such differences can exist not only among tissues and cells, but also at the subcellular level. Examples are abscisic acid ( $\mathrm{ABA}$ ) contents of primordia vs. scales of sour cherry (Prunus cerasus L.) buds (169), ABA transport to, and accumulation in, stomatal guard cells (159), and a phytochrome-induced redistribution of gibberellins (GAs) between etioplasts and cytoplasm within cells of cereal leaves (4l).

\section{Isolation}

Isolation methods generally involve organic solvent or aqueous extraction and diffusion (54, 104). Vascular 
exudates have been sampled through centrifugation (55) or pressurization (277).

Dennis (54) discussed assumptions and problems involved in extraction and in the diffusion method.

Dialysis is more effective than aqueous or solvent extraction to isolate GAs from cranberry (Vaccinium macrocarpon Ait.) tissue (154). Martin and Nishijima (160) discussed precautions against contaminants in solvents commonly used for extraction and analysis of GRs. Choice of soivents for extraction and fractionation is important. For example, methanol can cause transesterification of ABA (171), and acetone may form isopropylidene derivatives as artifacts of GA-diols such as $\mathrm{GA}_{32}$ (290). Another problem is extractability, e.g., direct solvent treatment of nacerated plant tissue does not extract protein- or membrane-associated GAs $(28,123)$.

\section{Purification}

Purification methods include solvent partition, several types of chromatography, such as paper, column, thin-layer, ion-exchange, gel permeation, gas liquid chromatography (GLC) and HPLC, or combinations of these (e.g., 104, 272). HPLC appears to be the method of choice $(23,243)$, for it offers high resolution, speed, high recovery, and larger column ioading capacity. Thus, with HPLC it is quite possible to collect several GRS from a single sample injection $(23,277)$. 
Plant extracts have been loaded into "preparative" HPLC directly $(13,23,36,228)$ or following solvent partition (5) and column (122), gel permeation (104, p. 45) or ion-exchange chromatography $(60,244,277)$. Reversed-phase columns are most commonly used for the HPLC analysis of GRs. Separations on this type of column are usually carried out by the ion-suppression mode. Thus, retention of GRs can be modified, not only by column temperatures and composition of the mobile phase, but also significantly by $\mathrm{pH}$ of the mobile phase (Wheaton, personal communication), just as on the ion-exchange columns $(243,245)$. Methylation preceding preparative HPLC was used to improve separation of $A B A$ (29). The Sep-pak (Waters Associates, Mass.) cartridges packed with the semi-HPLC materials have been used for initial cleanup of plant extracts prior to direct injection into the "preparative" HPLC (Mark L. Brenner, personal communication). Hubick and Reid (110) recently reported that $A B A$ can be readily separated from crude extracts of sunflower (Helianthus annus L.) leaves using silica Sep-pak with a series of solvent mixtures. ABA fractions were then partitioned into ethyl acetate followed by quantification by GLC with an electron capture detector (ECD) .

Adjusting $\mathrm{pH}$ during evaporation is recommended (23, 104):

with most extracts it is desirable to add sufficient alkali to the crude extract to 
maintain an approximately neutral $\mathrm{pH}$ in the final aqueous solution. After evaporation, the $\mathrm{pH}$ should be adjusted to about 8.0. These $\mathrm{pH}$ adjustments serve both to minimize isomerization of $\mathrm{ABA}$ to 2-trans-ABA ( $t-A B A)$, which occurs most readily in acidic solution, and more importantly to ensure that $\mathrm{ABA}$ is ionized in which state it is less likely to be lost by co-precipitation with waterinsoluble materials. (104, p. 129.)

on the other hand,

an aqueous fraction adjusted to $\mathrm{pH} 8$ with $\mathrm{NaOH}$ might have a $\mathrm{pH}$ approaching 12 as the sample reaches dryness. Selection of volatile buffering agents minimizes this problem. (23, p. 26.)

Low recovery, particularly of indoleacetic acid (IAA), is ciue to peroxidation, sublimation, and oxidation (158), and absorption into the glassware (23). Glassware can also be a source of contamination by fluorescent substances (288). IAA recovery was increased by adding $0.02 \%$ sodium diethyldithiocarbamate as an anti-peroxidant, by evaporating ether with a hotwater bath instead of a vacuum evaporator, by replacing ether with ethyl acetate, and by using nitrogen and an anti-oxidant (158). Silylation of glassware (23) and extensive rinsing of glassware with several solvents in series (288). were recommended.

Considerable reduction in dry weight and removal of interfering phenolic compounds can be achieved with polyvinylpyrrolidone (PVP). Insoluble PVP has been used during (5) or after homogenization in the form of a slurry followed by filtration (104, 153) or centrifugation 
(7), and as the medium in the column (76, 104, 249)

or for thin-layer chromatography $(250,260)$. Insoluble PVP, however, was reported as a source of contamination when using GC with an ECD (160).

\section{Quantification}

Quantification is the final step of GR analysis. It consists of analytical separation, detection and identification, quantitative measurement, and recovery check. Reproducibility, specificity, sensitivity and speed are important factors in considering each of these steps.

Modern analytical separations are performed by GLC or HPLC. Progress, however, on GLC techniques after Powell's review in 1972 (195) has been limited to types of derivatization, detectors and equipment mechanics, mainly electronics. Meanwhile, numerous reports on development of HPLC techniques for GRs have been published in recent years. Pool and Powell (194) were among the first to introduce HPLC for the separation of GRs, in this case cytokinins, in 1972. In 1978, Sweetser (243) reviewed fundamental history and basic concepts in HPLC, as well as examples of its applications to GR analysis.

Accuracy of identification and quantitative measurements are dependent on the separation system and the detector used. The main GC detectors are flame ionization 
(FID) for IAA, GAs, and cytokinins; ECD for $A B A$; and, most recently, the nitrogen-phosphorus detector for IAA (161) and cytokinins (297). For GA analysis, GC-MS may be the preferred system when cost is not limiting (122).

Hitherto reported HPLC detectors include ultraviolet spectrophotometer (UV), spectrophotofluorimeter (SPF), conductivity, and electrochemical devices (243). The UV detector is not very selective, but this can be countered by highly selective HPLC separation, determining the ratio at 2 wavelengths, and by coupling with other detector(s). Cytokinins (by UV) IAA, (SPF or electrochemical detector) and $\mathrm{ABA}$ (UV) are readily measured without any derivative formation. Thus, bioassays can be used to test physiological activity of these growth regulator fractions collected from "analytical" HPLC. Gibberellins, however, have to be "tagged" with a suitable compound for UV $(104,181)$ or SPF (48) detection. Sensitivity of the latter method is in the picogram range but there has been so far no report on its application to plant extracts. The sensitive barley endosperm bioassay is an alternative for GAs (277). UV and SPF detectors are useful to confirm the identity of growth regulators by scanning UV absorption or fluorescent excitation and emission spectra while stopping the HPLC flow. The "recycl.ng" HPLC technique is also useful to check the unity of a peak. Conversion of $A B A$ to $\underline{t}-A B A$ by $U V$ irradiation $(143,277)$ identifies $A B A$ in 
both GC-ECD and HPLC-UV systems. Finally, HPLC can be coupled with MS directly just as can GC (243).

Radioimmunoassay has been reported for analyses of IAA (191), ABA $(263,273,274)$, cytokinins (275) and GAs (72). The main advantages of radioimmunoassay are sensitivity and speed allowing analyses of several hundred samples per day. Ensuring specificity, however, remains to be solved. Cross reactions can occur involving conjugated $A B A$, methyl- $A B A$, $\underline{t}-\mathrm{ABA}$, phaseic acid, or dihydrophaseic acia $(263,273)$.

The improved indolo- --pyrone SPF method $(104,128)$ seems very attractive, but it cannot distinguish among IAA, 4-chloro IAA, and 5-hydroxy IAA. A fluorometric method has been used to determine GAs in several tissues, including citrus fruits (288), but its use is limited due to poor specificity and sensitivity (T.A. Wheaton, personal communication).

Precise quantitative analysis is accomplished by adequate recovery checking $(104$, p. 17, 131). An isotope dilution technique would be the most accurate one for this purpose, and HPLC has an advantage over GC in collecting sample fractions easily and precisely for subsequent scintillation counting (243). Additionally, the use of solvent controls for insuring no cross-contamination of G.S is recommended (104, p. 17). 
Endogenous Growth Regulators in Citrus Peel Tissues

Auxins, GAs, cytokinins, $A B A$ and inhibitors, and ethylene have all beer found in Citrus peel tissues $(78,177)$. Among peel tissues, the pigmented flavedo contains much more $\mathrm{ABA}$ (79) and GA-like substances (140) but less ethylene (111) than does the albedo. Quantitative estimates of the first 4 regulators are given in Table 1 . Reflecting the difficulty in analytical methodology, there have been few papers reporting quantities of hormones, especially auxins and cytokinins. The range of estimates of $A B A$ seems reasonable considering its nature as a "stress hormone" (40). There are, however, enormous differences among references on GAs. This large variation might not be due to differences in the sample tissues, season, or the growing area but rather to the analytical methods employed. Attention is drawn to the very high amounts reported in the last 3 samples of Table 1 despite use of a modern analytical method, GC-MS (38).

A similar large variation in estimates of GAs is reported for very young Citrus fruit. Wiltbank and Krezdorn (288) reported about $100 \mathrm{ng} \mathrm{CA}_{3}$ equivalent per gram fresh weight in Florida navel orange measured by a fluorometric method; however, Takahashi et al. (246) could find less than $0.05 \mathrm{n}_{\mathrm{j}} \mathrm{GA}_{3}$ equivalent per gram fresh weight in Japanese satsuma mandarin by a rice seedling test. 
These examples clearly indicate the importance of refining analytical methods. One purpose of this study was to develop an improved method for routine growth regulator analysis in grapefruit peel, patterned after the method of Wheaton and Bausher (277).

\section{Materials and Methods}

\section{Sample Preparation}

'Marsh' grapefruit were obtained from the Davenport grove of the Agricultural Research and Education Center, Lake Alfred. Strips, 4 rum-wide, of the flavedo layer were peeled from the equatorial portion of duplicated sets of 10 washed grapefruit with a mechanical apple peeler and cut into about $30 \mathrm{~mm}$-long pieces. Extraction and purification of IAA and ABA were based upon the method described by wheaton and Bausher (277). Samples were extracted with hot and cold ethanol, partitioned with petroleum ether, reduced in volume, and then separated initially into acidic (free ABA, IAA, GAs), basic (cytokinins), and neutral (bound $A B A$ ) fractions through ionexchange chromatography, as shown in Figure 1. Known aliquots of DL-cis-trans- $\left[2-{ }^{14} \mathrm{C}\right] \mathrm{ABA}(11.9 \mathrm{mCi} / \mathrm{mmol}$, Amersham) and 3 -indolyl $\left[1-{ }^{14} \mathrm{C}\right]$ acetic acid $(57.6 \mathrm{mCi} / \mathrm{rmol}$, Amersham) were added at the initial extraction step for recovery checks and final quantification. 
Reversed Phase HPLC

Preparative HPLC. A modular HPLC system (277) with a Waters $\mu$-Bondapak C-18 (300 × $3.9 \mathrm{~mm})$ or a Lichrosorb $\mathrm{RP}-8(250 \times 4.6 \mathrm{~mm})$ reversed phase analytical column was used for further purification of the acidic and alkaline hydrolyzed neutral fractions as described by wheaton and Bausher (277). A U6K injector and a pair of $\mathrm{M}-6000$ (A) pumps controlled by a solvent programmex $M-660$ were also used (Waters Associates). Eluate zones containing IAA or $A B A$ were collected based upon the retention times of the respective standards (Sigma Chemical Company) (Fig. 2-A). Analytical HPLC. Zone collections containing IAA and $A B A$ were analytically rechromatographed using the HPLC system employed for the preparative HPLC or with a separate single pump HPLC system. Chromatographic conditions are shown in Fig. $2-B$ and $2-C$ for $I A A$ and $A B A$, respectively. Detectors used were a Shoeffel SF/GF 770 or an IDC 1201-I variable wavelength UV monitor and an Aminco spectrophotofluorimeter.

Quantitative Measurement and Recovery Check

Radioactivity in the final IAA and $A B A$ fractions was counted by a liquił scintillation counter (Beckman LS-100) using Aquasol-2 (New England Nuclear) scintillation cocktail. Efficiency was $95 \%$ and quenching, as measured by the 
external standard ratio, was minor, thus sample counts were not corrected except for background subtraction. Amounts of IAA and $\mathrm{ABA}$ and percentage recoveries were calculated by the isotope dilution equation.

\section{Identification of $\mathrm{ABA}$ and IAA}

Chromatographic peaks were identified in several ways: retention times using several solvent plis were compared with those of authentic standards. Samples were fortified with small amounts of standards, one at a time, and rechromatographed checking increased peak height and peak symmetry. Eluate fractions were further rechromatographed at the same $\mathrm{pH}(6.5)$ after partition against ether or at a different $\mathrm{pH}$. Unity of a peak was examined by recycling the peak several times through the column. Stop flow fluorescence scans of IAA peaks were obtained manually and compared to those of the standard. Fractions containing $\mathrm{ABA}$ were rechromatographed with GLC-ECD as described by Chia et al. (34). Purity of $A B A$ peaks was further studied by an isotope dilution technique coupled with isomerization under UV light (143) changing from $A B A$ to $\underline{t}-\mathrm{ABA}$ as measured by HPLC rechromatography.

\section{Results and Discussion}

Growth regulators in grapefruit peel extracts were successfully separated by a combination of liquid 
chromatographic procedures. I typical chromatogram of the preparative reversed phase HPLC for IAA and ABA in a grapefruit flavedo extract is shown in Fig. 2-A. Zones corresponding to known retention times for IAA and $A B A$ were collected for rechromatography. This study did not involve GRs less polar than $\mathrm{ABA}$; hence ethanol concentration of the mobile phase was quickly increased up to $50 \%$ soon after the $A B A$ zone collections. The column was further eluted with $50 \%$ ethanol for 10 to 15 minutes at $2 \mathrm{ml} / \mathrm{min}$. to flush out the remaining nonpolar portion of samples. The system was then reversed to the initial condition for the next injection. This procedure routinely allowed one injection an hour. Other $\mathrm{GRs}$, such as $\mathrm{GA}_{1}, \mathrm{GA}_{3}$, bound $\mathrm{ABA}$, and $t-A B A$, were found to be eluted between IAA and $A B A$ in that order, and better separation and collection is possible by adjusting $\mathrm{pH}$ of the mobile phase when it is desired to do so. Both $\mu$-Bondapak $C_{18}$ and Lichrosorb RP-8 columns were equally suitable as a preparative step HPLC column.

Clean analytical separation of IAA and $\mathrm{ABA}$ in reasonably short times, 10 to 15 minutes, was achieved by an isocratic separation at higher $\mathrm{pH}$ and adjusted ethanol concentration (Fig. 2-B, 2-C). Separation of some samples was unsatisfactory, an additional HPLC separation at lower $\mathrm{pH}$ and higher ethanol concertration being necessary. Both $\mathrm{C}_{18}$ and $\mathrm{RP}-8$ columns gave essentially the same resolution. These tiwo columns, however, were superior to $\mu$-Porasil 
(277) or $\mu$ Bondapak- $\mathrm{NH}_{2}$ (34) in terms of better separation and reproducibility (data not shown). Practical detection limits were $1 \mathrm{ng}$ for IAA and $5 \mathrm{ng}$ for $A B A$, and the responses were linear up to the $10^{3} \mathrm{ng}$ range. The ability of HPLC to handle large injection volumes made these detection limits sensitive enough for this study.

Separation of IAA and $A B A$ using several different conditions and peak enrichment procedures with authentic standards identified both compounds (data not shown). Recycled HPLC of the ABA peak showed this peak to be composed of only 1 major constituent (Fig. 3-A). The $A B A$ zone collected from the preparative HPLC (Fig. 2-A) indeed contained $A B A$ when subjected to GLC-ECD, which is a fairly specific detector for $A B A$, and furthermore, amounts of $A B A$ recovered were clearly comparable to those by analytical HPLC (data not shown). Over 95\% purity of ABA of the ABA peak was confirmed by isotope dilution calculation after isomerization under UV light and HPLC separation (Fig. 3-B). The IAA peak was identified by its characteristic fluorescence spectrum (Fig. 3-C).

Average recoveries of added radioactive standards were $75 \%$ for $A B A$ and $60 \%$ for IAA within $\pm 5 \%$ for standards and $\pm 15 \%$ for samples in several years' analyses. In the author's opinion, this HPLC procedure coupled with the isotope dilution technique is a useful, reliable and precise method to analyze IAA and ABA quantitatively in grapefruit peel tissue. 
CHAPTER III

SEASONAL CHANGES IN RESISTANCE TO CHILLING INJURY AND ENDOGENOUS GROWTH REGULATOR LEVELS IN FLORIDA 'MARSH' GRAPEFRUIT FLAVEDO

\section{Literature Review}

Seasonal Resistance to Chilling Injury of Grapefruit

The traditionally accepted view has been that earlyseason grapefruit are extremely susceptible to chilling injury (CI) with tolerance to chilling temperatures increasing with advancing fruit maturity (155). This is curious because late, as well as early-season, susceptibility of grapegruit to CI was shown clearly by Harvey and R.ygg in 1936. They reported California desert grapefruit is susceptible to $\mathrm{CI}$ at $5.6^{\circ} \mathrm{C}\left(42^{\circ} \mathrm{F}\right)$ in November and December and again in the spring but tends to be resistant in mid-winter (94). According to Bates (17), also in 1936, "It is usually considered that early citrus fruit is more liable than late to physiological injury in cold storage. On the other hand, over-mature fruit is also stated to be very subject to cold storage injury. There would thus appear to be a certain period during the ripening of citrus fruits when they are comparatively resistant to physiological storage breakdown" (p. 4). Friend and Bach in 1932 (71), Nelson in 1933 (183) and 
Schiffmann-Nadel et al. in 1971 (225) also reported a similar trend for Texas, Florida, and Israeli grapefruit, respectively. Van der Plank (256) in South Africa discussed a striking analogy between Harvey and Rygg's data on seasonal susceptibility to CI (94) and his data on delayed storage experiments (see Chapter IV). Martin et al. (162) mentioned storage life of grapefruit decreased rapidly in the spring, immediately after bloom. Earlyseason Florida 'Marsh' and 'Ruby Red' grapefruit had a greater tendency to develop pitting than did more mature fruit according to chace et al. (30); whereas, late-season fruit tended to be more susceptible to "aging," stem-end rind breakdown, and decay. Pantastico (188) reported Florida 'Duncan' grapefruit picked in september was more susceptible to CI than fruit picked in July to August or in late October to late November. In 'Marsh,' however, pitting was high during the last part of July and middle of September and October. Harvey and Pygg (94) also noted that the pattern for seasonal susceptibility was different for $5.6^{\circ}$ and $0^{\circ} \mathrm{C}$ storage. Grapefruit were completely resistant until mid-winter at $0^{\circ} \mathrm{C}$, but were more susceptible to $\mathrm{CI}$ at $0^{\circ} \mathrm{C}$ than at $5.6^{\circ} \mathrm{C}$ in the spring. The amount of CI fluctuates graatly not only within a season but also among seasons (259). Trinidadian grapefruit grown in wet seasons was more susceptible to CI than in dry seasons (266). Van der plank (258) thought 
the difference in weather, mild vs. cold and wet, might be responsible for inconsistent results between the two seasons in his delayed storage experiments. Friend and Bach (71) also suggested harvesting grapefruit when the orchard soil was rather dry.

Hatton and co-worker(s) $(96,101)$ found early-season Florida grapefruit was most susceptible to $\mathrm{CO}_{2}$ injury at $4.5^{\circ} \mathrm{C}$ followed by late-season fruit which was more susceptible than midseason fruit. Pitting was induced only in the winter when they tested the effects of ethylene at non-chilling temperatures (97). Wardowski et al. (267) could reduce CI of early and midseason Florida grapefruit stored under differentially permeable films in an atmosphere with up to $20 \% \mathrm{CO}_{2}$, but these elevated $\mathrm{CO}_{2}$ levels increased CI of late, post-bloom grapefruit.

Grierson (85, 86) independently noted seasonal susceptibility of Florida grapefruit to CI similar to that reported by Harvey and Rygg (94). Systematic monthly pickings through the nine-month harvesting season of 1973-74 revealed a midseason peak in resistance to CI at $4.5^{\circ} \mathrm{C}(85)$. This winter peak in resistance to CI was later found in several other seasons (87). The extent of this mid-winter resistance to CI was found to be positively correlated with cieparture from normal average temperatures in the dry winter months (132). That seasonal variation in susceptibility of grapefruit to $\mathrm{CI}$ is 
definitely not a simple function of fruit maturity is confirmed by the curious interaction between $C I$ and the fungicide diphenyl, in which the use of diphenyl at $4.5^{\circ} \mathrm{C}$ greatly exacerbated the severity of CI in the fall and spring, but not in midseason pickings (165). Such a resistance pattern follows approximately the cycle of tree growth from the autumn flush through winter dormancy (quiescence) when resistance to $\mathrm{CI}$ is maximal, and subsequent bloom and spring growth. This growth cycle is generally considered to be controlled by growth regulators (GRs) as reviewed below. It was, therefore, hypothesized susceptibility to CI was under GR control (85).

Changes in Resistance to Chilling Injury of Fruit ${ }^{1}$ other Than Grapefruit

Maturity related. Susceptibility to $C I$ tends to decrease in many fruit with increasing maturity and ripeness, e.g. 'Persian' lime (Citrus latifolia Tan.) (188), banana (Musa sp.) (155, 188, 189), tomato (Lycopersicon esculentum Mill.) (164, 189, 213), mango (Mangifera indica I.) (235) and 'Honey Dew' melon (Cucumis melo L.) (150). The opposite is true in okra (Abelmoschus esculentus (L.) Moench) (113). Susceptibility of avocado (Persea anericana Mill.) to $C I$ is associated with its respiratory pattern, the fruit being only moderately susceptible in the pre-climacteric stage, most suscentible during the rise

${ }^{1}$ Fruit is used here in its botanical sense. 
to the climacteric peak, and comparatively resistant once the post-clinacteric phase is reached (137).

Preharvest weather related. Preharvest field temperatures affect the postharvest life of many fruit. Kader et al. (127) reviewed this subject for vegetables. Incidence of $\mathrm{CI}$ in mature-green tomatoes was positively correlated with hours below $15.6^{\circ} \mathrm{C}\left(60^{\circ} \mathrm{F}\right)$ during the week prior to harvest (179). Summer-grown tomatoes were much more resistant to CI than those in autumn (134) or winter (1) in England and Egypt, respectively. Temperature response of eggplant (Solanum melongena L.) in Japan was just opposite to that of tomatoes (3). Similar cucumber (Cucuris sativa L.) cultivars were more sensitive to $\mathrm{CI}$ when grown in a greenhouse than in the field. (11). 'Honey Dew' melons yellowed by sunshine in the field were more resistant to CI than those unaffected (151). Palmer (187) cited studies indicating bananas in Australia maturing at higher field temperatures were more susceptible than those maturing in a cooler climate. Core flush, a storage injury of 'Cox's Orange Pippin' apple (Malus sylvestris Mill.) was more severe when the average summer temperature had been low (291). Lower night temperatures prior to harvest induced more red color and less storage scald of 'McIntosh' (252), 'Stayman' (168), and 'starking Delicious' (186) apples. Srock (233) mentioned "---if the weather the last six weeks of the growing season is hot and dry, apple scald is likely to be severe. If the weather is cool with adequate rain one can anticipate light 
scald" (p. 23). On the other hand, rain increased susceptibility to CI of California fall-grown tomatoes according to Morris (178).

Changes in Endogenous Growth Regulators During Fruit Maturation

There are a number of excellent reviews on hormonal control of fruit ripening $(56,167,219)$. The term "ripening" has been used in a broad sense rather than applied strictly to climacteric-type fruits in which the process is preceded or accompanied by a rapid rise in respiration rate. No such stage is discernible in citrus (236).

Climacteric fruits. One of the most detailed documentations of hormonal changes from anthesis through ripening is reported for cherry tomatoes (Lycopersicon esculentum Mill. cv. Small Fry). Cytokinins and auxins were abundant at the early stages, reaching their peaks during the cell division stage, then leveling off. Levels of GA were more prominent during the cell enlargement period with a peak before the mature green stage. Levels of $\mathrm{ABA}$ increased gradually reaching a maximum in the mature green stage. Ethylene evolution was low until just before the mature green stage, then rose rapidly to a maximum at the pink stage (2). These data fit Dillye's model (56) very well, in which a combination of decreasing GA and increasing $A B A$ result in a higher rate of ethylene 
synthesis which in turn induces ripening. A rise in $A B A$ was observed, however, in avocado fruit following an increase in ethylene production rather than vice versa (6). Rudnicki and co-workers have also shown that $A B A$ increases during ripening of apples (216), pears (215), and strawberries (217).

Non-climacteric fruits. Hormonal changes similar to those for cherry tomatoes (2), except for ethylene, were found in grapes (Vitis vinifera L.) (114). In this fruit, $A B A$ levels increased concomitantly with the onset of the stage III growth (veraison), continued to rise reaching a maximum of about sixteenfold over that of a week before veraison, and then declined to a low level as maturity of the berries increased (42). During (59) reported most of the $A B A$ in the berries is transported from the leaves at the time when sucrose begins to accumulate in the berries. Salt stress did not affect the maximum concentration of $\mathrm{ABA}$ in berries but displaced the time of the onset of rise in $\mathrm{ABA}$ and of veraison (57). Increases in $A B A$ during fruit maturation of sour cherry (Prunus cerasus L.) (52) and French prune (P. domestica L.) (205) have also been reported.

Citrus fruits. A rapid decrease in "citrus auxin" concentration auring the early stages of fruit development and then a moderate decrease during later stages of fruit growth was observed in navel oranges (C. Sinensis (L.) 
Osbeck), and an auxin antagonist increased rapidly in the latter period (149). The "citrus auxin," however, was later found to be scopoletin, which is not active in the Avena curvature test (82). Inhibitors, nevertheless, were found to accumulate also in 'Shamouti' orange during fruit growth (83). Cellulase and $A B A$ in flavedo and ethylene in fruit of Florida oranges were found to increase gradually during maturation (202). No clear seasonal trends in hormonal contents were observed in maturing California citrus peel (38). On the other hand, seasonal changes in GA-like compounds and ABA levels in Japanese satsuma (ㄷ. unshiu Marc.) peel were found to be analogous to those of cherry tomatoes (2) or grapes (114). Levels of GA-like substances in satsuma flavedo decreased rapidly in september, then leveled off toward maturity. Levels of $\mathrm{ABA}$ increased gradually during early fruit enlargement and then increased rapidly to a very high value during maturation $(140)$. Later, this $A B A$ increase was found to peak in early December, decreased rapidly to about half of the maximum concentration during December, then remained constant until February (141). Regreening in Florida 'Valencia' oranges was found to be associated with an increase in GA-like activity in flavedo (201). This is in agreement with results in which exogenously applied potassium gibberellate caused regreening in 'Valencia' orange $(39,64)$ and grapefruit (37). 
Changes in Growth Regulators in Fruits as Affected by. Grove Environment

Florida oranges need about 5 nights below $10^{\circ} \mathrm{C}$ to induce a change in peel color from green to orange (239). This color change is probably due to endogenous ethylene induced by the stress of cold nights (45). The following reports indicate temperature stress-induced ethylene production may be $A B A-m e d i a t e d$. Wang et al. (265) found controlled cold nights induced accumulation of $A B A$ in 'Bartlett' pear; they speculated high $\mathrm{ABA}$ involves stimulation of ethylene production, premature ripening, and abscission. It is known $A B A$ stimulates ethylene production in calamondin leaves (43) and 'Shamouti' orange peel discs (75). Moreover, $A B A$ applied to trees increased coloring of 'Temple' and 'Murcott' fruit in Florida (44).

However, it should be borne in mind ethylene is known to increase $A B A$ in citrus peel tissues (see chapter IV); hence, it is quite possible that cold stress may directly stimulate ethylene production which, in turn, could accelerate both $\mathrm{ABA}$ synthesis and consequent coloring of the fruit. Fruits can synthesize $A B A$ endogenously (see Chapter IV); however, many reports (19, 59, 105, 296) support the view that $A B A$ is synthesized in mature leaves and transported into fruit. 
Changes in Endogenous Growth Regulators in overwintering Plant Tissues

"Overwintering" includes such physiologically distinct phenomena as frost hardiness, winter dormancy or quiescence, and vernalization. These are, however, closely related processes in terms of plant adaptation to climate. Seasonal changes in resistance to $\mathrm{CI}$ of grapefruit seemed to coincide with the growth cycle of the tree in the overwintering period (85). General considerations of endogenous and exogenous growth regulators in relation to dormancy $(133,142,222,270)$ and frost hardiness. $(8,126,147)$ also have been reviewed. Effects of low temperatures, short days (long nights), water stress and combinations of these on levels of endogenous growth regulators are discussed.

Low temperatures. Many developmental changes in higher plants result from shifts in temperature regimes. The most common are those following termination of dormancy, vernalization, and stratification. Changes in endogenous GAs most probably control these processes (124). There is, however, a question as to whether GAs directly regulate the processes of thermoinduction or, alternatively, play a role in the post-induction state. Levels of GAs increased during stratification of hazel nut (Corylus avellana L.) and beech seeds (Fagus sylvatica L.) (70) and vernalization of winter wheat (Triticum sp.) seeds 
(204). A decrease in growth inhibitors and an increase in auxins were also reported in the vernalized seeds. On the other hand, levels of diffusible GA-like substances in crown apices of strawberry (Fragaria hyb.) remained low during chilling requirement periods ( 2 to 4 months at $\left.-1^{\circ} \mathrm{C}\right)$. Levels increased only upon transfer from chilling conditions to growth chambers, or after very long chilling treatments ( 6 to 8 months) when spontaneous sprouting occurred. These levels of GA-like substances were lowered by AMO-1618 [ammonium (5-hydroxycarvacryl) trimethyl chloride piperidine carboxylate].(16). It was suggested a reduction in $\mathrm{ABA}$ content during an earlier stage of chilling (182) might be a prerequisite for adequate biosynthesis of GAs in the post-chilling growth period. Reid et al. (206) determined frost hardiness and measured GA content in wheat (Triticum aestivurn L. subsp. aestivum) seedlings grown continuously from seeds under 4 temperature regimens, $2^{\circ}, 2^{\circ}$ then transferred to $20^{\circ}$, $6^{\circ}$, and $20^{\circ} \mathrm{C}$. An increase in frost hardiness $\left(2^{\circ} \mathrm{vs}\right.$. $6^{\circ} \mathrm{C}$ ) was associated with a large decrease in GA level, but the largest increase in frost hardiness $\left(6^{\circ}\right.$ vs. $20^{\circ} \mathrm{C}$ ) was associated with relatively little change in overall GA content. It was concluded that although GAs may play a role in controlling the level of frost hardiness of wheat, they are not the most important factor (206). Irving (115) found that frost hardiness in box elder 
(Acer negundo L.) induced under long days plus $5^{\circ} \mathrm{C}$ nights was associated with an increase in $\mathrm{ABA}-1$ ike and a little decrease in GA-like activities.

Cytokinin and GA-like substances in xylem exudate decreased but $A B A$ activity increased with lower temperatures when maize (zea mays L.) was grown at soil temperatures between $8^{\circ}$ and $33^{\circ} \mathrm{C}$ (14). There is also evidence that low temperatures increase "bound" GAs with a concomitant decrease in "free" GAs within tulip (Tulipa so.) bulbs, winile the reverse was true at higher temperatures (15). Additionally, effects of lower temperatures on metabolic activities, turnover, and transport of hormones should not be overlooked.

Short days. Nitsch (184) has pointed out that under short day conditions, auxin and GA levels are low and levels of growth inhibitors (including $A B A$ ) are relatively high. This hormone balance favors frost hardiness (115, 261). Irving and Lanphear (116) and Irving (115) found $A B A-l i k e$ activity was high in box elder under short days but low under long days, while the inverse was true for GA-like compounds. Howell and Weiser (107) reported acclimation to cold in apple bark occurs in 2 stages induced by short days and frost (or low temperatures), respectively. Short days stimulated leaves to produce translocatable substance(s) which promoted cold acclimation, 
but hardiness induced by low temperatures did not involve translocatable factors.

Many temperate zone woody plants form terminal buds in short photoperiods. It has been widely believed $A B A$ increases in plant tissues during short days (61). Several recent reports, however, revealed ABA content does not seem to increase in shoot tips under short-day conditions, and in fact may decrease $(144,196,227)$. A possible reason for this discrepancy is poor separation between GAs and $A B A$ followed by bioassays in some earlier reports.

Low temperatures and short days. This combination has been used as an inductive condition in many cold hardiness experiments. Changes in the balance of endogenous ABA-like and GA-like substances similar to that found in box elder cited above, occurred in alfalfa (Medicago sativa L.) seedlings as they cold-hardened. The changes were due more to a decrease in GA-like rather than an increase in $\mathrm{ABA}-1$ ike compounds (261). A reduction of at least one step in GA synthesis, ent-kaurene synthesis, a greater stability of bound than free GA-like compounds, and a total decrease in GA-like activity were associated with induction of cold hardiness in black locust (Robinia pseudoacacia L.) seedlings (185).

$\mathrm{ABA}$ seemed to have a metabolic role in promoting cold hardiness of crown tissue of winter wheat. Levels 
of this inhibitor increased strikingly under a gradual cold plus short day treatment but there were no significant effects upon auxin, GAs, nor clear-cut changes in cytokinins when all of these were analyzed by gas-liquid chromatography (280). Perry and Hellmers (192) showed a treatment with short days plus low night temperatures caused an increase in ABA content in red maple (Acer rubrum $L$ ) foliage. The increase in $A B A$ level was a thousand-fold in both northern (Massachusetts) and southern (Florida) races; however, only the former developed true winter dormancy. Low temperatures and short day conditions seem to have separate roles in inducing cold hardiness of apple bark as mentioned above (107).

Water stress. Boussiba et al. (22) reported tobacco (Nicotiana tabacum L.) plants pre-exposed to leaf dehydration, salination, mineral deprivation, or boron $\left(\mathrm{BO}_{3}{ }^{3-}\right.$ ) toxicity exhibited increased resistance to $-8^{\circ} \mathrm{C}$ and reduced oxygen in the root medium. Levels of $A B A$ in leaves vere elevated by all of these prior stress treatments. Moreover, exogenously applied ABA improved resistance of leaves to both freezing and oxygen stresses. Leaf $\mathrm{ABA}$ content also declined together with a loss of induced resistance to freezing and oxygen stresses upon return of salinated or mineral-deprived plants to normal conditions. Based upon these results, it was suggested, regulation by a common hormone, $A B A$, might be a mechanism 
involved in "cross-adaptation" (22). The concept of cross-adaptation proposed by Hale (91) holds exposure of an organism to a given adverse environment modifies its resistance to other stress factors. This is analogous to Levitt's "general tolerance hypothesis" (146, p. 565) in which a common mechanism involved oxidation-reduction or exchange reactions of membrane proteins via their sulfhydryl (SH) and disulfide (SS) linkages.

Rapid wilting of cabbage (Brassica oleracea L.) leaves achieved by excision of shoots induced as rapid and high a degree of freezing resistance as did a similar period of hardening at low temperature (47). Water stress also effectively induced cold hardiness of containergrown grapefruit and orange trees. This was associated with increases in leaf proline and sugars (292). Abscisic acid may also have been involved in these systems. Low temperatures, short days, and water stress. According to Chen and Li (33), all 3 of these factors initially trigger independent frost hardiness mechanisms in 2- and 4-month old red osier dogwood (Cornus stolonifera Michx.). This conclusion, however, was only deduced from the observation that the effects of the 3 factors were additive without statistically significant interactions. It is still quite possible one (or more) common regulator(s) mediates biochemical changes due to these 3 stress factors. This view is supported by another report by the same 
authors (32) that water stress and short days accomplish essentially the same physiological and biochemical end(s) when inducing frost hardiness of dogwoods. Moreover, Yelenosky has reported $(291,292)$ the same biochemical changes were found whether cold hardiness of citrus trees was induced by low temperature or by water stress.

Seasonal conditions. Seasonal changes in endogenous growth regulators under outside conditions have been studied in relation to cold hardiness of both a herbaceous plant (69) and perennials $(8,147)$ and also with regard to dormancy for the latter (133, 222, 270).

The onset of dormancy is, generally speaking, accompanied by an increase in inhibitors and a decrease in promoters. The reverse occurs with the breaking of dormancy (e.g. 133). Caution is necessary when interpreting data based on bioassays after paper or thin-layer chromatography because it is well known that separation of GAs and inhibitors such as $A B A$ is very difficult and these substances compete with each other in many bioassays. Changes, nonetheless, in promoter-inhibitor balance rather than in individual regulators may be physiologically more important. Moreover, recent reports have confirmed $A B A$ increases in buds of many deciduous perennials in autumn and/or winter (e.g. 58). Eugene and Dennis (67) showed clearly annual defoliation prevents autumn accumulation of $\mathrm{ABA}$ in flower primodia of sour 
cherry without affecting the intensity of rest. Cytokinins in sugar maple (Acer saccharum Marsh) roots and stems (247) and in willow (Salix viminalis L.) shoots (9) also increased in the spring and were associated wiht increasing soil temperatures.

It seems the same trends in hormonal changes that occur in deciduous trees also occur in evergreen citrus trees. Monselise et al. (176) reported low levels of promoters and an early December peak of inhibitors in dormant buds of Israeli 'Shamouti' orange. A decrease in $\underline{t}-\mathrm{ABA}$ and an increase in GAs precede spring growth of California 'Valencia' orange buds (125). Cooper et al. (46) found grapefruit leaves produced a bud growth inhibitor(s) upon which potassium gibberellate had an antagonistic effect. There was a period of relatively low GA-like activity during late autumn and winter, at the time of flower formation, and a peak in February, at the time of spring flush and flowering in trunk and branch bark of 'Shamouti' orange. Low GA activity was again evident at the end of flowering, followed by another peak when the summer growth flush started. February and May peaks in GA-like activity also occurred in the shoots with an additional peak in october (262). Growth Regulators and Chilling Injury in Plants

Auxin. Tumanov and Truniva (251) reported in 1958 the amount of free, as well as bound, auxin in the tissues 
of winter plant coleoptiles decreased upon cold hardening. This decrease in auxin was caused not only by low temperatures, but also by an increase in sugars in the cells. Moreover, the ability of coleoptiles to harden was reduced when a high concentration $(200 \mu \mathrm{g} / \mathrm{mI})$ of IAA was added to a $12 \%$ sucrose medium (251). Haard and Timbie (90) found peroxidase recoverable from green banana fruit declined during initial stages of chilling and subsequently increased after approximately 7 days at $5^{\circ} \mathrm{C}$ when severe chilling was manifest. The direct influence of chilling temperatures on the affinity of banana peroxidase for auxin in vivo was investigated (89). The break in linearity of substrate velocity plots occurred at temperatures coincident with those known to promote CI of bananas. Haard concluded from these results and those of Tumanov and Truniva that responses of IAA oxidase to low temperatures may have a causal relation with $\mathrm{CI}$.

The IAA oxidase system is thought to influence plant growth by regulating the concentration of endogenous IAA. Plant tissues capable of rapid growth exhibited low total IAA oxidase activity; whereas, higher IAA oxidase activities were observed in slower growing tissues (73). Recent studies have shown levels of IAA oxidase activity may be affected by environmental stress in the form of low temperatures (20) or water stress $(49,173)$. Pre- and postharvest applications of 2,4-D 
(2,4-dichlorophenoxyacetic acid) to Florida grapefruit affected CI oppositely. Preharvest spray decreased but postharvest application increased susceptibility to CI (118) .

Cytokinins. Shirakawa et al. (229) determined effects of benzyladenine (BA) treatment on cut Anthurium flowers at the variable temperatures often encountered during transport from Hawaii to major markets in the mainland U.S. Benzyladenine treatments were generally found to impart some tolerance to chilling and to extend the salable period. Respiration rates of flowers held continuously at $21^{\circ} \mathrm{C}$ were reduced by $\mathrm{BA}$. Inhibition of respiration was more pronounced with immature than with mature flowers (229). Kuraishi et al. (139) investigated resistance to CI of intact plants after treatment with $\mathrm{BA}$ at $2 \times 10^{-5} \mathrm{M}$ using corn (Zea mays L.). Two days after spraying, plants were chilled at $-2^{\circ} \mathrm{C}$ for 3 hours. There was less injury on BA-treated plants.

Pre- and postharvest application of BA to Florida grapefruit affected CI oppositely, as with 2,4-D mentioned above. The authors concluded their evidence supports the hypothesis that growth regulators control CI (see Chapter I), although the type and magnitude of the response was neither consistent nor predictable (118). Inconsistencies may be explained by seasonal changes in endogenous conditions such as hormonal balance. The 
opposite response between pre- and postharvest applications may be due to an interaction between responses of leaves and fruit to preharvest applications of growth regulators. A paper from China (109) stated that BA could enhance chilling tolerance of banana fruit and also confirmed the effect of thiabendazole in ameliorating $\mathrm{CI}$ in addition to its effect as a fungicide. Reduction of CI by thiabendazole was first found with grapefruit in Israel by Schiffmann-Nadel et al. (224) and later in Florida (268) and Cyprus (136). Thiabendazole was found to reduce ozone injury to leaves of pinto beans (Phaseolus vulgaris L.) (190), ethylene dibromide fumigation injury to citrus peel (3I) and CI-like storage injury to $\underline{c}$. hassaku Hort. ex Tan., a grapefruit-like Japanese late-season citrus (135). Schiffmann-Nadel et al. (223) pointed out the effect of thiabendazole and benomyl might be related to a decrease in the rate of senescence, citing references for its cytokinin-like activities. A recent report suggests endogenous lipoxygenase control and lipidassociated free radical scavenging as modes of cytokinin action in plant senescence retardation (145). This report is particularly interesting in relation to functions of membrane lipids (156) and free radicals (264) upon the mechanism of $\mathrm{CI}$.

Gibberellins. As mentioned above, several reports suggest that GA is an inhibitor of frost hardiness. There 
is evidence that this is also true for chilling tolerance, i.e., colchicine greatly exacerbated CI of cotton cotyledonary tissues, probably by affecting microtubules, while it had no effect on the tissue at $26^{\circ} \mathrm{C}$. Pretreatment with $\mathrm{GA}_{3}$ enhanced the effect of colchicine on CI (208). On the other hand, $\mathrm{GA}_{3}$ reduced low-temperature-storagebreakdown of 'Jonathan' apples (282) but $A B A$ and auxins increased this injury (283). This physiological disorder, however, may not be comparable to CI. Yields of pangolagrass (Digitaria decumbens stent.), a tropical pasture plant, were reduced when night temperatures dropped to $10^{\circ} \mathrm{C}$. This effect is associated with increased starch content and decreased amylolytic activity, dry weight, and leaf area. Application of $\mathrm{GA}_{3}$ at $10^{-5} \mathrm{M}$ reversed these low temperature effects (129). Applied $\mathrm{GA}_{3}$ may have induced a reversal of dormancy (quiescence), a plant adaptation to low temperature stress possibly mediated by $\mathrm{ABA}$ (see above section in this Chapter), through its effect on synthesis of amylolytic enzymes.

Ismail and Grierson (118) showed postharvest application of $\mathrm{GA}_{3}$ at $500 \mathrm{ppm}$ tended to increase $\mathrm{CI}$ of Florida grapefruit. This was particularly true with February and March pickings of the 1973-74 season, and it seemed to the authors $\mathrm{GA}_{3}$, showed the seasonal resistance to CI toward earlier harvests. Not only CI but also decay was mitigated by $500 \mathrm{ppm}^{\mathrm{G} A_{3}}$ plus $100 \mathrm{ppm} \mathrm{BA}$ 
and 44 ppm 2,4-D applied to grapefruit harvested in midMarch (118). Both of these trends have been confirmed in recent small scale tests (K. Kawada and W. Grierson, unpublished data).

Ethylene. Many forms of stress, including chilling temperatures, are known to induce or increase ethylene production in plant tissues (4).

Mature-green grapefruit on small trees contained 100 ppm ethylene after a 14 -day $20^{\circ} / 5^{\circ} \mathrm{C}$ (20-hour day/night) treatment, as compared to $4 \mathrm{ppm}$ for fruit on trees held at $25^{\circ} / 20^{\circ} \mathrm{C}$. Night temperatures of $5^{\circ}$ and $10^{\circ} \mathrm{C}$ occurring during late October in Florida caused an increase in ethylene production in 'Pineapple' oranges. Detached 'Robinson' tangerines stored at $20^{\circ} / 5^{\circ} \mathrm{C}$ for 10 days produced 20 times more ethylene than did fruit stored at $20^{\circ} / 20^{\circ} \mathrm{C}$ (45). Ethylene production in storage by $\underline{\mathrm{C}}$. natsudaidai Hayata, a Japanese "summer grapefruit," was much higher at $1^{\circ} \mathrm{C}$ which causes $\mathrm{CI}$, than at $6^{\circ} \mathrm{C}$ which did not, even though visible symptoms of CI had not yet appeared at $1^{\circ} \mathrm{C}$. Fruit at $1^{\circ} \mathrm{C}$ with pitting lesions produced twice as much ethylene as did sound ones. Moreover, $500 \mathrm{ppm}$ ethylene during storage at $6^{\circ} \mathrm{C}$ induced a peel injury which resembled CI at $1^{\circ} \mathrm{C}$ (119). In contrast, Vakis et al. (255), working with Florida 'Marsh' grapefruit, found no increase in ethylene production during l-month storage at chilling temperatures either with or 
without ethylene up to $500 \mathrm{ppm}$. They also noted in their logbook on this experiment that there was neither CI-like pitting at $10^{\circ} \mathrm{C}$ nor an increase in $\mathrm{CI}$ at $4.5^{\circ} \mathrm{C}$ from exogenous ethylene applied during storage. Hatton and Cubbedge (95, 97), also working with Florida 'Marsh' grapefruit, found ethylene up to $200 \mathrm{ppm}$ during 3-month storage at nonchilling temperatures induced CI-like peel pitting only with a small percentage of winter fruit but never with autumn or spring fruit. High-ethylene rind injury was observed only in spring. They also noted ethylene increased weight loss during and after the storage period. Increased weight loss due to lower humidity during storage at chilling temperatures is known to increase CI of 'Duncan' grapefruit and 'Persian' limes (188). Pantastico in Florida (188) and Eaks in California (63) did not measure ethylene but reported very sharp increases in respiration of Florida 'Persian' limes, and of California 'Valencia' oranges and 'Eureka' lemons subsequent to storage at chilling temperatures. Such increases in respiration would presumably be accompanied by increased ethylene production.

Pratt and Biale (197) reported in 1944 that chilled 'Fuerte' avocados produced enough ethylene to cause a triple response in etiolateō pea seedlings, though not until the fruit had been at $5^{\circ} \mathrm{C}$ for 57 days. When Cooper et al. (45) measured ethylene by gas chromatography, chill-susceptible 'Simpson' and 'Booth 7 ' avocados held 
at $5^{\circ} \mathrm{C}$ for 3 days produced more ethylene than those kept at $20^{\circ} \mathrm{C}$. Chill-resistant 'Lula' avocados, however, produced less ethylene after storage at $5^{\circ} \mathrm{C}$ than when held at $20^{\circ} \mathrm{C}$. Young and Lee $(294)$ recently reported that 'Fuerte' avocados in $50 \mathrm{ppm}$ ethylene were injured severely at both $6^{\circ} \mathrm{C}$ and $9^{\circ} \mathrm{C}$; whereas, those in air were injured only very slightly at $6^{\circ} \mathrm{C}$. They stated the presence of ethylene in low temperature storages might account for C.I appearing at higher than expected temperatures. This could be explained by ethylene induced phenylalanine ammonia-lyase (PAL) activity which is known to cause russet spotting of lettuce (Latuca sativa L.) leaves (112). Green peppers under chilling stress produced enough ethylene to cause an induction of PAL which controls production of chlorogenic acid, the main phenolic substance causing discoloration of pepper seeds exposed to chilling temperatures (138).

On the other hand, prestorage ethylene treatments mitigated CI of 'Honey Dew' melons (284) (see Chapter IV). Apeland (10) working with cucumbers observed a similarity in the symptoms of CI and those due to ethylene treatments at non-chilling temperatures. Later, he found ethylene production of cucumbers at non-chilling temperatures was low; at $5^{\circ} \mathrm{C}$ it was much higher, and upon transfer from $5^{\circ}$ to $12.5^{\circ} \mathrm{C}$ there was a tremendous initial increase in ethylene production (12). Both ethylene production at 
$5^{\circ} \mathrm{C}$ and $\mathrm{CI}$ symptoms of cucumber were decreased by delayed storage treatments (II) (see Chapter IV). Ethylene production by okra fruit during and after storage at chilling temperatures was similar to that of cucumbers. Increased ethylene evolution at $2.5^{\circ}$ and $5^{\circ} \mathrm{C}$ was observed well before appearance of visible symptoms of CI. The longer the chilling exposure at $5^{\circ} \mathrm{C}$, the higher the rate of etinylene evolution following transfer to $20^{\circ} \mathrm{C}$ (113). Increased ethylene production occurred during and after chilling of bean seedlings, although the increase was entirely attributable to a water deficit that accompanied the chilling responses (289).

Abscisic acid. Evidence that higher endogenous $A B A$ levels relative to GA levels promote frost hardiness has been mentioned above. Exogenous $A B A$ has also been reported to increase frost hardiness in box elder (116), apple (106), and alfalfa (212) seedlings. The higher the ABA content induced by several stress treatments, the greater was the frost resistance of tobacco plants (22). These results encouraged Rikin's group (210) to study the effects of $A B A$ on $C I$. Applied $A B A$ to cucumber seedlings reduced $\mathrm{CI}$, as indicated by decreased cellular leakage, tissue dehydration, appearance of necrosis, and inhibition of overall growth (210). Chilling injury was also reduced when cucumber seedlings were pre-stressed by salinization of the root medium or by water deprivation, conditions well 
known to elevate ABA levels (209). This is another example of cross-adaptation (22).

Presumably, the beneficial effects of $A B A$ are mediated through its effects in reducing water loss. This view is supported by Wright (289) who proposed cellular water deficit as an essential prerequisite for CI, by Wilson (285) who controlled CI of bean seedlings by maintaining a water-saturated atmosphere around the leaves and by closing stomata with either applied or stress induced $\mathrm{ABA}$, and by Christiansen and Ashworth (36) who were able to reduce CI of cotton seedlings with the application of antitranspirants.

Rikin and Richmond (211), nevertheless, recently reported that $\mathrm{ABA}$ influences responses of cucumber cotyledons to chilling temperatures not only by maintaining water balance of the chilled tissues but also by decreasing damage caused by chilling temperatures per se. These findings were strengthened by their subsequent experiments with cotton seedlings. Intact cotton seedlings and isolated cotton cotyledonary discs were exposed to chilling temperature under humid conditions which prevented dehydration. There was marked reduction in the levels of reduced glutathione and membrane phospholipids without losses of electrolyte or necrosis within the first 2 and 3 days of chilling. pretreatment with $A B A$ completely prevented these reductions (207). Moreover, 
pretreatment with $A B A$ greatly decreased the effect of colchicine in exacerbating $\mathrm{CI}$ of cotton cotyledonary tissues. It is suggested that $A B A$ (and GA) may play a role in the regulation of tissue response to chilling by affecting the membrane and microtubular systems (208). More recently, Borman and Jansson (2l) reported ABA increased both chilling resistance and frost hardiness of callused tobacco pith explants, and suggested at least part of the ameliorating effects of $A B A$ resulted from an increase in the levels of proline.

Hitherto reviewed evidence on the beneficial effects of $A B A$ on $C I$ has been limited to seedlings and callus, but it also seems to be true for some mature fruits. ABA, succinic acid-2,2-dimethylhydrazide (SADH, Alar or B-9), or chlorocholine chloride (CCC) applied to mature-green tomatoes (108) and SADH to bananas (109) have increased resistance to CI. Grapefruit CI was also reduced by a prestorage 50 ppm $A B A$ dip in a small scale test ( K. Kawada and W. Grierson, unpublished data).

If $\mathrm{ABA}$ could reduce transpiration of mature fruits, CI of many fruits could be partially controlled with $A B A$ because there are many reports showing reduced CI of mature fruits resulted from minimizing transpiration, as with seedlings mentioned above. Examples are waxing of grapefruit $(30,84)$, cucumbers (180), but not limes (100, 188); increased storage humidity with grapefruit, 
limes, bananas (188), cucumbers (180), and peppers (180, 232); and film wrapping of grapefruit (84, 131).

\section{Materials and Methods}

'Marsh' grapefruit were harvested biweekly from a single $\mathrm{S}-\mathrm{N}$ row in the Agricultural Research and Education Center Lake Alfred's Davenport grove planted in 1960. The rootstock was rough lemon (‥ jambhiri Lush.) and the soil type, Astatula fine sand. Picking was random, about 10 fruit from each of 15 trees in 1977-78, 20 in 1978-79, and 35 in 1979-80, including high and low, inside and outside fruit at about 9 a.m. Immediately after each harvest, fruit were washed with FMC Fruit cleaner 220 over brushes, dxied, graded and sized but not waxed. Mix-sized samples of 40 fruit were packed into bagmaster fibreboard cartons. One carton was stored immediately at $5^{\circ} \mathrm{C}$, a temperature selected for maximurn development of CI as manifested by surface pitting, and about 85 to $90 \%$ RH. (Other cartons vere used for delayed storage treatments in Chapter IV.) One carton was also stored immediately at $10^{\circ} \mathrm{C}$ in early and late 1979-80. Chilling injury was rated weekly on a 0-100 scale with a value of 10 representing the onset of visible injury as previously described (85). Resistance to $\mathrm{CI}$ was expressed as number of storage days at $5^{\circ} \mathrm{C}$ needed to reach a mean CI score of 10 . Fruit were discarded when CI clearly exceeded this score. 
Growth regulators were anlyzed by the methods described in Chapter II using 2 sets of 10 fruit chosen at random from an entire biweekly harvest. Two $5 \mathrm{~g}$ flavedo samples were oven dried at $70^{\circ} \mathrm{C}$ for 2 days to check percentage dry weights. Peel color was read with a Hunter D25D Color and Color Difference Meter, the $a / b$ ratio being taken at 3 locations around the equatorial plane of 15 (1977-78) or 30 (1978-79 and 1979-80) fruit used later for delayed storage treatments, and averaged. The $a / b$ ratio is negative for green fruit, approximately zero for yellow fruit, and increases in positive value through orange and red and has previously been demonstrated to correlate well with observed visual peel color and with the USDA color standards for citrus $(242,279)$. Internal quality of 20 fruit in the 1979-80 season was ascertained using official florida methods (269). Climatological data at Lake Alfred (about $20 \mathrm{~km} \mathrm{SW}$ from the Davenport grove) as reported by NOAA, National Weather Service, Ruskin, FL., were used.

\section{Results and Discussion}

Resistance to Chilling Injury Following Immediate Storage

Grapefruit stored at $5^{\circ} \mathrm{C}$ immediately after harvest were quite susceptible to CI at most picking dates during all 3 seasons studied (Figs. 4-A, 5-A, 6-A). An extended midseason period of resistance to $C I$ has been reported for 
the 1973-74 season (85). Similar midseason periods of resistance were found in this study, but only for grapefruit subjected to prestorage conditioning treatments as reported in Chapter IV.

Fruit stored at $5^{\circ} \mathrm{C}$ immediately after harvest in 1977-78 reached the onset of CI after approximately 25 days (Fig. 4-A). Fruit harvested in July and August were somewhat more resistant, and there were 3 harvest dates in February and March with substantial resistance. The peak of this resistant period was about 1 month later than for the lowest mean monthly minimum field temperature preceding these harvests (Fig. 4-B). The correlation between these 2 variables $(r=0.55)$ was not significant. Rygg and Harvey's (218) positive correlation between temperature, as the average for 5 days before harvest, and degree of CI also could not be confirmed.

In 1978-79, immature fruit harvested in August were quite resistant to CI while fruit harvested in mid-October were most susceptible (Fig. 5-A), thus corroborating previous data for 5 seasons (87). Only one harvest in midseason showed slightly elevated resistance to $\mathrm{CI}$. Approximately 30 days were required to reach the onset of CI for most harvest dates. Seasonal changes in minimum field temperatures were similar to those in 1977-78, but the midseason weather was rather irregular with 2 minor freezes and subsequent unusual heavy rain (Fig. 5-B). 
During most of 1979-80, fruit stored immediately after harvest showed the onset of CI after approximately 20 days at $5^{\circ} \mathrm{C}$ (Fig. 6-A). There were 2 transitory periods of increased resistance, one in March and another in April. The extent of the first peak was delineated by a picking from the same row of trees on March 7 between these biweekly pickings on March 3 and 17 (A.C. Purvis, unpublished data). Purvis' and the author's values on resistance to CI on other harvest dates throughout this season were very close, thus justifying this interpolation and indicating that this system for evaluating CI resistance of grapefruit is reproducible and consistent. There were unusual late season light freezes on the mornings of March 3 and 4 . Nevertheless, the lowest mean minimum field temperature for the 30 days preceding harvest occurred prior to the February 18 picking (Fig. 6-B).

The period of resistance to $C I$ at $5^{\circ} \mathrm{C}$ in each of these 3 seasons was transitory: only one or a few pickings in late winter to early spring showed any considerable resistance (Fig. 4-A, 5-A, 6-A), as compared to the several months long resistant period in 1973-74 (85). These results, however do confirm previous findings that late-season grapefruit is as susceptible to $\mathrm{CI}$ at $4.5^{\circ} \mathrm{C}$ to $5^{\circ} \mathrm{C}$ as is early-season fruit $(85,87)$.

Various hypotheses have been proposed to explain midseason resistance to CI (85, 94, 198). Rygg and 
Harvey (218) thought the midseason resistance to CI of California desert grapefruit was attributable to its seasonal physiological activity. Fruit harvest in midseason apparently had a lower respiratory rate as measured by sealing a fruit in a jar with a manometer. Grierson (85), on the other hand, thought midseason resistance was due to seasonal diminished tree-growth activity at the time of harvest. Periods of vigorous tree-growth were presumably related to low resistance to $\mathrm{CI}$, with increasing resistance during periods of tree dormancy. Highly transitory resistant periods and the resistance of immature fruit harvested in August shown in the current study do not support either of these views for grapefruit stored immediately after harvest.

Additional tests of fruit stored at $10^{\circ} \mathrm{C}$ immediately after harvest in 1979-80 showed that early-season fruit were moderately susceptible (average days to onset of CI was 30) but late-season fruit were very resistant to CI (average days to onset of CI was over 100) at this temperature. It is apparent that seasonal trends in resistance to $\mathrm{CI}$ differ sharply according to the storage temperatures.

Peel Color and Resistance to Chilling Injury

Peel color was measured at each harvest date for all 3 seasons. Peel color was quite green for initial pickings 
in each season $(a / b=-0.6)$, increased steadily to yellow in February $(a / b=+0.1)$, and declined slightly thereafter (Figs. 4-B, 5-B, 6-B).

Degreening commenced about 2 weeks earlier and a somewhat deeper yellow color was achieved in 1978-79 than in 1977-78 (Figs. 4-B, 5-B). In 1979-80, the onset of degreening was about 10 days to 2 weeks later than in 1977-78 and about 4 weeks later than in 1978-79 (Fig. 6-B). The $a / b$ colorimetric ratio for the $1979-80$ season exceeded the first season's value early in January and reached that of 1978-79 late in January.

Only in 1977-78 was there a significant correlation $(r=0.72, p<0.05)$ between resistance to $C I$ and $a / b$ ratio after the fruit matured (i.€. November to Juiy). The previously suggested involvement of either peel pigments or the plastids containing them in resistance to CI (85) is not supported by this work with grapefruit stored immediately after harvest.

Seassonal Trends in Growth Regulators in Grapefruit Flavedo

Levels of $I A A_{1}$ and $A B A$ in the flavedo were determined throughout both the 1977-78 and 1978-79 seasons. Seasonal changes in percentage dry weight of the flavedo were minimal, thus levels of GRs were expressed on a fresh weight basis. Levels of IA 1 remained relatively constant throughout both seasons at about $10 \mathrm{ng} / \mathrm{g}$ fresh weight (Figs. 
$4-C, 5-C)$. Levels ranged from 9 to $12 \mathrm{ng} / \mathrm{g}$ fresh weight in 1977-78 and 4 to $15 \mathrm{ng} / \mathrm{g}$ fresh weight in 1978-79.

slightly higher levels of IAA toward the end of 1978-79 might have been due to hedging (severe pruning) in March, 1979. The levels of IAA found in this study were similar to those reported by Erner et al. (66) as "only a small but significant amount was detected" in the flavedo of 'Shamouti' oranges. Slightly higher levels, also in 'Shamouti,' were reported by Goren and Goldschmidt (83) and much higher levels were reported by Coggins and Johns (38) for 'Marsh' grapefruit and other citrus peel (Table 1).

Both free and bound $A B A$ were determined, and distinct seasonal variations were found (Figs. 4-C, 5-C, 6-C). Free $\mathrm{ABA}$ in 1977-78 ranged from a low of $20 \mathrm{ng} / \mathrm{g}$ fresh weight for early and late pickings to a midseason peak of about $350 \mathrm{ng} / \mathrm{g}$ fresh weight. Bound $A B A$ had a midseason peak of about 2,500 ng/g fresh weight (Fig. 4-C). In 1978-79, 3 peaks of free ABA were observed with values in the 500 to $850 \mathrm{ng} / \mathrm{g}$ fresh weight range (Fig. 5-C). Bound $A B A$ reached a peak in March of nearly 9,000 ng/g fresh weight. A range of free and bound $A B A$ levels in citrus peel tissues have been reported by various workers (Table 1). The range found in this study generally agrees with these reports, except for the much higher values reported for California citrus (38).

The general trend in $A B A$ levels, i.e. an increase with maturation in winter and decrease with over-maturity in 
spring, tended to be in agreement with previous reports for citrus peel $(140,141)$ and for other overwintering tissues $(69,142,222)$. However, neither peel maturity, as indicated by peel color, nor photoperiod seen to be directly related to changes in $A B A$ levels.

Monthly minimum field temperatures were negatively correlated with free $\mathrm{ABA}(\mathrm{r}=-0.83, \mathrm{p}<0.01)$, but not with total or bound $\mathrm{ABA}$ in 1977-78. Peaks in free $\mathrm{ABA}$ in 1978-79 seemed to be induced by adverse conditions such as freezing weather (Fig. 5-A, 5-B). Wang et al. reported that chillinglevel field temperatures could lead to an increase in ethylene and $A B A$ (265) in pear fruit. Cooper et al. (45) also showed that ethylene in citrus fruits was increased by chilling temperatures. There are several reports that $\mathrm{ABA}$ induces ethylene synthesis $(43,75)$ and vice versa $(24,81)$. ABA levels in grapefruit flavedo analyzed just before, during and after the Narch 1980 freeze were found to increase rapidly soon after the freeze (Fig. 7). This increase could be due not only to temperature stress but also to water stress. A freeze is accompanied by higher evapotranspiration and the latter stress is well known to increase $\mathrm{ABA}$ content in many plant tissues (e.g. 170). There was no detectable $(<0.05$ ppm) ethylene within grapefruit even after the freeze. 
Relationship Between Seasonal Changes in Growth Regulators and Resistance to Chilling Injury of Grapegruit Stored Immediately after Harvest

Although the midseason period of resistance was not well defined for fruit stored at $5^{\circ} \mathrm{C}$ immediately after harvest, the midseason peaks in $A B A$ occurred roughly in the time of transitory periods of increased CI resistance. Both free and bound $A B A$ started to increase well before midseason resistance to CI was apparent in 1977-78 (Fig. 4). Free ABA had already started to decrease by the peak of resistance to $\mathrm{CI}$, but bound $\mathrm{ABA}$ was still high. Thus, the correlation between resistance to $C I$ and bound $A B A$ was greater $(r=0.87, p<0.01)$ than that with free $A B A$ $(r=0.66, p<0.05)$. In 1978-79, there were 3 peaks of free $A B A$ but these did not parallel resistance to CI (Fig. 5). Bound $A B A$ exhibited only one peak which corresponded with the time when resistance to CI appeared, but the correlation was not significant apparently due to the very brief period of resistance. Immature fruit were resistant to $C I$ even when $A B A$ levels were low.

The reported positive effect of free $A B A$ on reducing CI of seedlings $(207,209)$ does not seem to be an important factor of seasonal resistance to CI of grapefruit. A peak in bound $\mathrm{ABA}$ coincided with that of resistance to $\mathrm{CI}$ in 2 seasons (Fig. 4, 5), but bound $A B A$ itself is known to be very limited in its activity as a GR and it is thought to be merely a metabolite rather than a pool for free $A B A$ 
(170). Metabolic conditions induced by certain environmental factors which cause a build-up in bound $A B A$ might have a role in resistance to $\mathrm{CI}$ of grapefruit rather than the higher levels of bound ABA itself. In other words, higher free $A B A$ content at the time of harvest cannot be linked with resistance to CI directly but a steady supply of free $A B A$ might. Consistently high levels of free $A B A$ would induce certain metabolic changes, including build-up of reducing sugars (198) and bound ABA (Figs. 4, 5). It is logical to hypothesize that some of these metabolic changes induce resistance to $\mathrm{CI}$ either directly or by further modification in metabolism that in turn make the tissue resistant to $\mathrm{CI}$. 


\begin{abstract}
CHAPTER IV
EFFECTS OF CONDITIONING TREATMENTS ON * SEASONAL RESISTANCE TO CHILLING INJURY AND ON ENDOGENOUS GROWTH REGULATOR LEVELS IN FLORIDA 'MARSH' GRAPEFRUIT FLAVEDO
\end{abstract}

\title{
Literature Review
}

Mocification of Resistance to Chilling Injury of Grapefruit anc other Plant Tissues by Conditioning Treatments

Terminology. The term "conditioning" has been used with reference to chilling injury (CI) in a sense similar to that of hardening or acclimation against freezing stress, although the physiological processes are not necessarily the same. Postharvest conditioning requires a certain delay period prior to storage, thus the term "delayed storage" is a practical expression in postharvest handling as opposed to "immediate storage," while "conditioning" is a physiological expression. Treatments involving exposure of plant materials to temperatures slightly above the chilling range for a certain time prior to placing them at a chilling temperature have been called "temperature conditioning" (11, 156, 278). This is in contrast to so-called "curing" (also described as wilting, quailing or sweating and occasionally used as synonyms of degreening or coloring) which is performed at temperatures well above the chilling range (e.g. 27). Conditioning 
treatments include not only temperature conditioning and curing but also initial ethylene (degreening) or $\mathrm{CO}_{2}$ treatment and gradual temperature lowering (stepdown cooling).

Grapefruit. Many experiments on curing to mitigate CI of grapefruit have been reported. Curing was often recommended as a commercial practice and a short period curing at high temperature and high relative humidity (RH) conditions (such as the Florida degreening conditions, $29.5^{\circ} \mathrm{C}$ and 90 to $95 \% \mathrm{RH}$ ) is still considered beneficial to induce wound healing and so decrease penicillium rots (117). Hawkins (102) and Hawkins and Barger (103) recommended curing Florida grapefruit either by exposing the fruit to air at $21^{\circ} \mathrm{C}$ to $25^{\circ} \mathrm{C}$ and about $65 \% \mathrm{RH}$ for 1 to 2 weeks or by treating it with gas from a kerosene stove in a degreening room for 3 to 4 days. Both treatments decreased pitting in $0^{\circ} \mathrm{C}$ storage, but the latter treatment was considered better, because during the degreening process the buttons were loosened and removed by subsequent washing and brushing. This, in turn, decreased stem-end rot (103). It should be borne in mind that these grapefruit were stored in Washington, D.C., or in Virginia, and it took from 8 to as many as 20 days to ship them from Florida. Friend and Bach (71) have reported that scald, as well as pitting, of mexas grapefruit was reduced by holding the fruit at $21^{\circ} \mathrm{C}$ 
for 10 days before $0^{\circ} \mathrm{C}$ storage; however, neither ethylene nor stove gas degreening treatments were effective. Brooks and McColloch (27) reported that a 4-day delay at $15.6^{\circ} \mathrm{C}$, 3 days at $21^{\circ} \mathrm{C}$ to $24^{\circ} \mathrm{C}$, or 17 to 22 hours at $37.8^{\circ} \mathrm{C}$ decreased pitting at $2.2^{\circ} \mathrm{C}$, but the higher temperature increased CI (pitting and scald) at $0^{\circ} \mathrm{C}$. They also noted that eifectiveness of delay at $10^{\circ} \mathrm{C}$ was dependent upon the period involved; i.e., 2-day delay was not effective at all, whereas 7 to 10-day delay was beneficial and the effect of 2 -week delay was not consistent. Florida grapefruit used for these experiments were also shipped to, or purchased in, Washington, D.C., and then stored irmediately or after certain delays. Johnson et al. (121) considered the fact Florida grapefruit were much more resistant to $C I$ than Texas-grown ones in a storage test in Texas was the result of an enforced delay during transit from Florida to Texas. However, neither Harding et al. (93) nor Chace et al. (30) found beneticial effects on CI of Florida grapefruit from a 60-hour delay at $29^{\circ} \mathrm{C}$ or 5 - to 10 -day delay at $15.6^{\circ} \mathrm{C}$, respectively. Extensive studies of the effect of delayed storage to mitigate CI of grapefruit have been done in South Africa. Davies and Boyes (51) quantified delay in terms of percentage weight loss during delay treatments. They found the effect of delay varied with subsequent storage temperatures, there being an optimum degree of wilting at each temperature which correspcnded to a loss of weight 
from 3.3 to $5.0 \%$. The protective effect was reduced if wilting was continued beyond the optimum. Van der Plank (256, 258) confirmed the existence of such optima but in terms of days of delay instead of percentage weight loss. A delay of about 1 to 2 days at $26.7^{\circ} \mathrm{C}$ and $90 \%$ RH was optimum, too much delay being as bad as, or worst than, immediate storage at $3.9^{\circ} \mathrm{C}$. At $18.3^{\circ} \mathrm{C}$, the optimum delay was about 4 to 6 days and there was less tendency for subsequent injury to increase when too long a delay was given. Treatment with $167 \mathrm{ppm}$ ethylene at the lower temperature increased the beneficial delay effect (256). Grierson (85) reported recently a 2-day delay under Florida degreening conditions, both with or without $5 \mathrm{ppm}$ ethylene, increased resistance to CI at $4.5^{\circ} \mathrm{C}$ of Florida 'Marsh' grapefruit picked early or late in the season when it is not naturally resistant to CI. Exposing grapefruit for 20 to 48 hours to atmospheres containing 20 to $45 \% \mathrm{CO}_{2}$ before storage at $0^{\circ} \mathrm{C}$ resulted in a definite decrease in the subsequent development of pitting as compared to similar lots held at the same temperatures in normal air, according to Brooks and McColloch in 1936 (27). Recent studies have also shown prestorage exposure to $\mathrm{CO}_{2}$ up to $40 \%$ for 3 to 7 days at $21^{\circ} \mathrm{C}$ significantly reduced rind pitting (99) and stemend rind breakdown (98) of Florida grapefruit stored at $4.5^{\circ} \mathrm{C}$ for 8 to 12 weeks. Delay, however, for the same period and at the same temperature in air was as 
effective as in $\mathrm{CO}_{2}$ (99). Thus, the necessary delay period prior to storage involves some uncertainty. as to how much of the effect is due to $\mathrm{CO}_{2}$ per se and how much is due to delay alone.

An attempt to mitigate CI of grapefruit by stepdown cooling was unsuccessful. Gradual lowering of the storage temperature reduced CI of bananas and avocados (climacteric fruits) but no such effects were observed on limes and grapefruit (non-climacteric fruits) (188).

Other fruits. McColloch (163) found CI of peppers (Capsicum annuum L.) at $0^{\circ} \mathrm{C}$ could be mitigated by prior exposure to $10^{\circ} \mathrm{C}$ for 5 to 10 days. Ilker (113) reported conditioning at $12.5^{\circ} \mathrm{C}$ or $15^{\circ} \mathrm{C}$ for 2 days was insufficient to reduce $\mathrm{CI}$ of okra, but a 4-day conditioning at these temperatures was sufficient to reduce $\mathrm{CI}$ at $5^{\circ} \mathrm{C}$ for 4 or 6 days but not for 8 days. Conditioning at $15^{\circ} \mathrm{C}$ was more effective than at $12.5^{\circ} \mathrm{C}$.

Apeland (11) reportea the susceptibility to CI of cucumbers at $5^{\circ} \mathrm{C}$ for 4 or 6 days was decreased with temperature conditioning for up to 4 days. Comparison of 2 prestcorage temperatures, $12.5^{\circ} \mathrm{C}$ vs. $20^{\circ} \mathrm{C}$, showed the latter was more effective in reducing $C I$. Ethylene production at $5^{\circ} \mathrm{C}$ was lowest for cucumbers treated at $20^{\circ} \mathrm{C}$, intermediate for those conditioned at $12.5^{\circ} \mathrm{C}$, and highest for those fruit placed directly at the chilling temperature. Another exaniple is 'Honey Dew' melons as 
reported recently by Lipton and Aharoni (151). Exposure at $20^{\circ} \mathrm{C}$ to $1,000 \mathrm{ppm}$ ethylene for 24 hours before storage at $2.5^{\circ} \mathrm{C}$ for 2.5 weeks virtually eliminated objectionable CI. A subsequent report (152) showed ripening of these muskmelons had progressed during the ethylene treatment, which may in turn have modified susceptibility of the fruit to $C I$.

Gradual lowering of the storage temperature by steps of $3^{\circ} \mathrm{C}$ at 12 - or 24 -hour intervals reduced subsequent $\mathrm{CI}$ of bananas and avocados as compared to those transferred directly from $20^{\circ} \mathrm{C}$ to $5^{\circ} \mathrm{C}(188)$. There are a number of papers on delayed storage $(25,200)$ and initial high $\mathrm{CO}_{2}$ treatments $(26,193)$ used to mitigate cold storage disorders of apples. However, these disorders may not be comparable to $C I$ of tropical and subtropical fruits.

Ornamentals. Spranger (237) found temperatureconditioned greenhouse ornamentals were less susceptible to $\mathrm{CI}$ than control plants grown at room temperature. More recently, resistance to $C I$ of 2 species of foliage plants has been increased by exposure to low, but not chilling temperatures in the light (232).

Seedlings. Wheaton and Morris (278) showed 5-day-old 'Rutgers' tomato seedlings grown at $25^{\circ} \mathrm{C}$ were conditioned against 2-day chilling at $1^{\circ} \mathrm{C}$ more effectively at $12.5^{\circ} \mathrm{C}$ than at $10^{\circ}, 15^{\circ}, 20^{\circ}, 25^{\circ}$, or $30^{\circ} \mathrm{C}$. Eggplant (Solanum melongena L.) and corn seedlings responded similarly. A 
conditioning period of as little as 3 hours at $12.5^{\circ} \mathrm{C}$ was sufficient to give some protection, but maximum protection was achieved with 48 hours' exposure. The protection, however, was effective only against moderate chilling and no seedlings survived chilling at $1^{\circ} \mathrm{C}$ for 7 days. In contrast to seedlings, conditioning of sweet potato (Ipomoea batatas (L.) Lam.) cuttings influenced respiration only slightly and did not reduce $\mathrm{CI}$ symptoms. It was suggested that the relatively low metabolic rate of roots might be a limiting factor in temperature conditioning of sweet potatoes (278). Cotton seedlings germinated at $30^{\circ} \mathrm{C}$ for 2 days were chill-hardened by growing them successively at $30^{\circ}, 25^{\circ}, 20^{\circ}$ and $15^{\circ} \mathrm{C}$ for 2 days each (220).

An early report showed resistance to CI of seedlings of several species could be achieved by controlling water supply (226). It has been demonstrated bean leaves car: be "drought-hardened" over a 4-day period at $25^{\circ} \mathrm{C}$ by withnolding water from the roots until the leaves wilt and these drought-hardened leaves are as resistant to CI as leaves "chill-hardened" for 4 days at $12^{\circ} \mathrm{C}$ and $85 \% \mathrm{RH}$ (284). Such conditioning of seedlings has been used to stuảy biochemical mechanisms of CI as discussed below.

Mechanisms Involved in Conditioning to Induce Resistance to Chilling Injury

Increased unsaturation of fatty acid. It has been postulated resistance to $\mathrm{CI}$ is due to the ability of a 
membrane to remain in the liquid crystalline state at chilling temperatures through increased unsaturation of fatty acids (147, 156, 157).

Wilson's group $(286,287)$ studied the effects of temperature conditioning on the degree of unsaturation of the fatty acids in leaves of seedlings and found there was no increase in unsaturation (287). The degree of saturation did, however, increase during conditioning of Gossypium hirsutum $L$. and phaseolus vulgaris L., but only in the phospholipid fraction, which represented only $22 \%$ of the total leaf fatty acids. Moreover, the degree of unsaturation and the proportion of phospholipid decreased in the leaves of these species with increased physiological age at $25^{\circ} \mathrm{C}$ and was related to the increased susceptibility of older leaves to CI (286).

A direct confirmation of the relation between unsaturation of fatty acids and chilling resistance induced by conditioning was reported by $\mathrm{St}$. John and Christiansen (220). The proportion of linolenic acid in the polar lipid fraction increased when they gradually lowered growth temperatures of cotton seedlings. The conditioning effect was greatly reduced by chemically inhibiting synthesis of linolenic acid.

Increased unsaturation of total fatty acids during acclimatization to frost injury has also been reported in 
winter wheat seedlings (53) and in alfalfa roots (74) and in phospholipids of winter rape seedlings (234). Energy supply. Steward and Guinn (241) found a progressive decrease in adenosine triphosphate (ATP) content of cotton seedlings during chilling at $5^{\circ} \mathrm{C}$. Chilled plants returned to growing conditions were able to restore the initial ATP content after chilling for 1 day, but not when chilled for 2 days. The decrease in ATP with chilling was prevented by prior conditioning of seedlings at $15^{\circ} \mathrm{C}$ for 2 days with 14 -hour day length. Levels of ATP in conditioned plants were higher than in control plants and increased in leaves but decreased in roots (24l). It has, in fact, been possible to protect cotton seeds against $C I$ in the field by application of AMP (166). According to Wilson (285), a reduction in ATP supply below that necessary to maintain metabolic integrity of cytoplasm is not considered to be important in development of CI of Episcia reptans Mart. or Phaseolus vulgaris L. as ATP level decreased only after the onset of visible leaf injury.

Pantastico (188) showed the ratio of inorganic phosphate esterified/oxygen absorbed ( $\mathrm{P} / \mathrm{O}$ ratio) by mitochondria in grapefruit held at $4.5^{\circ} \mathrm{C}$ was much lower than that of those held at $15.5^{\circ} \mathrm{C}$. Subsequently, Vakis et al. (254) reported CI of grapefruit was associated with a breakdown of the ATP/ADP energy transport system 
and was at least partially controllable with high $\mathrm{CO}_{2}$ during storage.

Sugars. Guinn (88) sought a possible relationship between conditioning to $\mathrm{CI}$ and hardening against frost injury. Young cotton plants exposed to $15^{\circ} \mathrm{C}$ for more than 2 days prior to chilling at $5^{\circ} \mathrm{C}$ showed some resistance to CI. Sugars and starch increased in conditioned plants, but protein, ribonucleic acid (RNA) and lipid-soluble phosphate decreased (88). Purvis et al. (198) reported mid-season resistance to $\mathrm{CI}$ of Florida grapefruit was strongly correlated with levels of reducing sugars. Santarius (221) found sugars to protect chloroplast membranes subjected to temperature and water stress. Air temperatures of $10^{\circ} \mathrm{C}$ caused an increase in sugar content of leaves and stems of 'Valencia' orange, which was associated with frost hardiness (293).

Growth regulators. There is no report of a possible relationship between conditioning-induced resistance to $\mathrm{CI}$ and endogenous growth regulators. Studies, nevertheless, by Goldschrnidt's group in Israel. $(24,77,80,81)$ suggest effects of delayed storage treatments on resistance to CI may be growth-regulator mediated. Abscisic acid ( $A B A$ ) increased and gibberellins (GAs) decreased during natural and ethylene-induced senescence of citrus fruit peel (77, $80,81)$. Benzyladenine ( $3 A$ ) delayed ethylene-induced 
accumulation of free and bound $\mathrm{ABA}$, but $\mathrm{GA}_{3}$ had no effect on endogencus $A B A$ levels (24). An increased $A B A / G A$ ratio might increase resistance of plant tissues to $\mathrm{CI}$, as reviewed in Chapter III.

\section{Materials and Methods}

Fruit samples were prepared, scored, and analyzed as described in chapter III. A carton of 40 fruit and 2 sets of 10 fruit for GR analysis were used per treatment per harvest.

\section{Treatments in 1977-78 were:}

A. Immediate storage at $5^{\circ} \mathrm{C}$.

B. Held at $20^{\circ} \mathrm{C}$ and $90+\%$ RH with about 5 ppm ethylene for 3 days then stored at $5^{\circ} \mathrm{C}$.

c. Held in a roof penthouse for 3 days to simulate traveling through the high veldt in South Africa; held at $38^{\circ} \mathrm{C}$ and ambient RH for 3 days then stored at $5^{\circ} \mathrm{C}$, after November when mean daily temperature dropped.

Treatments in 1978-79 were:

A. Immediate storage at $5^{\circ} \mathrm{C}$.

B. Held at $29^{\circ} \mathrm{C}$ and $90+\frac{\mathrm{RH}}{\mathrm{f}}$ for 3 days then stored at $5^{\circ} \mathrm{C}$.

C. Held at $29^{\circ} \mathrm{C}$ and $90+\% \mathrm{RH}$ with about 5 ppm ethylene for 3 days then stored at $5^{\circ} \mathrm{C}$.

D. Held in a roof penthouse for 3 days then stored at $5^{\circ} \mathrm{C}$.

E. Held at $29^{\circ} \mathrm{C}$ and ambient $\mathrm{RH}$ for 3 days then stored at $5^{\circ} \mathrm{C}$. 
Treatments in 1979-80 were:

A. Immediate storage at $5^{\circ} \mathrm{C}$.

B. Held at $29^{\circ} \mathrm{C}$ and $90+\frac{8}{\mathrm{RH}}$ for 3 days then stored at $5^{\circ} \mathrm{C}$. C. Held at $29^{\circ} \mathrm{C}$ and $90+\%$ RH with about 5 ppm ethylene for 3 days then stored at $5^{\circ} \mathrm{C}$.

D. Held at $29^{\circ} \mathrm{C}$ and $100 \% \mathrm{RH}$ for 3 days then stored at $5^{\circ} \mathrm{C}$. Temperature and $\mathrm{RH}$ during 3-day treatments were recorded with hygrothermographs. In the last 2 seasons, weight loss during 3-day treatments were checked on 10 fruit per treatment per harvest.

\section{Results and Discussion}

Resistance to Chilling Injury Following Delayed Storage

Postharvest prestorage conditioning treatments (delayed storage) significantly increased CI resistance of grapefruit in all 3 seasons studied (Figs. 4-A, 5-A, 6-A) confirming previous reports $(27,51,85,103)$. Response to the 2 conditioning treatments in 1977-78 was quite different. A delay of 3 days at $29^{\circ} \mathrm{C}$ and $90+\%$ RH with 5 ppm ethylene (delayed storage "A") was less effective than 3 days in a hot penthouse (delayed storage "B") in the early season. Delayed storage "A" was more effective after November when delayed storage "B" was switched to holding fruit at $38^{\circ} \mathrm{C}$ and ambient RH for 3 days (Fig. 4-A). It appeared from these results that there might be optimum conditions for the 3-day postharvest prestorage 
conditioning treatment. A report from So. Africa (51) showed delayed storage causing 3 to $5 \%$ weight loss, dependent upon storage temperature, was most effective in increasing CI resistance. Thus, the experiment in the next season, 1978-79, was designed to determine if weight loss during delay could be a parameter of effectiveness of conditioning. Five treatments in 1978-79 resulted in a wide range of prestorage weight loss ranging from 0 to $5 \%$ as season averages (Table 2). Resistance to CI was doubled by all conditioning treatments. The treatment effect on CI resistance was obviously confounded by the wide change through the 8-month harvesting season, in fact the replication (picking date) variable as well as the treatment variable were both significant at the 1\% level. From this, the correlations between prestorage weight loss and CI resistance were studied not only with the all season data but also with early-, mid-, and late-season data separately. Linear regressions were not statistically significant lut every data set fitted second degree polynomials at $1 \%$ level (Fig. 8). These curves show 1) resistance to CI (and hence storage life) at $5^{\circ} \mathrm{C}$ is maximal at about $3 \%$ prestorage weight loss; 2) effect of prestorage weight loss is sharply seasonal being most effective in midseason. The best fit curve for each harvest was computed and plotted on a 3-dimensional graph (Fig. 9) showing dynamic seasonal changes. It is immediately 
apparent: 1) prestorage weight loss had less effect with the very early pickings when the trees were still quite vegetative; 2) as the trees went dormant, prestorage weight loss had an increasing effect on CI resistance; 3 ) this effect diminished sharply in the late-season when the trees resumed active vegetative growth.

The above correlation between prestorage weight loss and CI resistance is based on the assumption that time delay before storage per se has no effect on increasing $C I$ resistance; i.e. data from the immediate storage treatment were used as the $0 \%$ weight loss data, but all other data were from the delay storage treatments, thus there is a 3-day time lag between these data. Subsequently, the 1979-80 experiment was designed to see if 3 -day delay at 100\% RH affects CI resistance. As a result, even in a water-saturated condition which caused some weight gain, a 3-day delay did significantly increase CI resistance (Fig. 10). The mean value in CI resistance of the treatment at $100 \% \mathrm{RH}$ was lowest but was not significantly different from other treatments at $90+\%$ RH. These data clearly indicate time delay per se increases CI resistance independent of weight loss, and this could be a reason for the fact that the best-fit curves in the 1978-79 experiment (Figs. 8, 9) always gave higher CI resistance values for the $0 \%$ weight losis than the actual. 
A peripheral, but important, observation is time span and conditions between picking and storage may be much more influential than most intentional treatments. This point should be kept in the researcher's mind, not only when conducting experiments but also when reviewing literatures. Variations in delay periods and associated conditions would also be reasons for the fact in commercial shipments that some lots are very susceptible to CI while other lots from the same grove are quite resistant. Effect of ethylene during delay was also investigated. Friend and Bach (71) reported ethylene to have no effect on $\mathrm{CI}$, but van der Plant (258) found ethylene to reduce CI especially when delay periods were beyond the optimum. The latter author pointed out a possible interaction between ethylene and RH during delay. Grierson (85) reported ethylene reduced CI only when the fruit were green. Current results in both 1978-79 (Table 2) and 1979-80 (Fig. 10) show ethylene to have no additional effect during delay at $29^{\circ} \mathrm{C}$ and $90+\frac{\circ}{\mathrm{RH}}$ even when fruit were green (data not shown). Prestorage ethylene treatment, however, seemed to be beneficial in reducing stem-end rot by loosening buttons (103) and in reducing green mold by enhancing wound healing processes (G.E. Brown, unpublished data). 
Conditioning Effects on Endogenous ABA Levels

Levels of $\mathrm{ABA}$ in the flavedo were analyzed before and after the conditioning treatment in 1978-79. All treatments increased free $A B A$ levels (Fig. 11) confirming Goldschmidt and co-workers' reports (e.g. 24). The treatment, nevertheless, at low $\mathrm{RH}$ causing as much as $5 \%$ weight loss gave less increase in free $A B A$ than the penthouse treatment, which resulted in about $2 \%$ weight loss. Increase in free $\mathrm{ABA}$ at $29^{\circ} \mathrm{C}$ and $90+\% \mathrm{RH}$ was also much less than that in the penthouse treatment, while ethylene gave some additional increase (Fig. 11). A pattern similar to that between prestorage weight loss and free $A B A$ levels was reported between plant water potential and free $A B A$ levels in cotyledonary leaves of cotton seedlings (50). Bound $A B A$ levels were also increased during the conditioning period but less than for free $\mathrm{ABA}$ (Fig. 11). Unlike free $\mathrm{ABA}$, the treatment at low RH increased bound $A B A$ more than the penthouse treatment did. Ethylene increased bound $A B A$ much more than free $A B A$ possibly by activating turnover metabolisms of $A B A$. Goldschmidt (77) also reported ethylene increased bound $A B A$ much more than free $A B A$ in 'Shamouti' orange peel. The general pattern of prestorage conditioning on free ABA levels is well correlated with that on resistance to CI (Fig. 11). This is ir. the agreement with Rikin and co-workers $(207,208,209)$ on the role of ABA controlling CI 
in seedlings. Wilson (286) reported that water stress rather than low temperature is the primary factor inducing resistance against $C I$ in bean seedlings subjected to low temperature or drought hardening. Presumably ABA is mediating such "hardening" (conditioning) systems. There are, however, some questions on the correlation between ABA levels and CI resistance of grapefruit: 1) for some pickings, conditioning at $29^{\circ} \mathrm{C}$ and $90+\% \mathrm{RH}$ without ethylene increased CI resistance as much as or even more than for the treatment at the same conditions plus ethylene or at the same temperature but at low $\mathrm{RH}$, but without an increase in $\mathrm{ABA}$ as much as that of the last 2 treatments; 2) the experiment in 1979-80 showed CI resistance can be increased by delay without any weight loss.

Relationship Between Seasonal Condition-induced Resistance to Chilling Injury and Levels of Growth Regulators at the Time of Harvest

As mentioned above in relation to prestorage weight loss, the effect of conditioning on CI resistance was strikingly seasonal (Figs. 4-A, 5-A, 6-A). These data indicate midseason fruit have a greater potential for CI resistance which can be induced by conditioning treatments. such potential is minimal in mature early-season fruit (i.e October pickings) and later diminishes in late-season fruit. Thus, even midseason CI resistance of immediately stored fruit was not apparent in 1978-79 and 1979-80, 
conditioned fruit clearly showed the existence of midseason resistance. These midseason resistance patterns were generally associated with mean minimum field temperatures and with $A B A$ levels (Figs. 4-C, 5-C) supporting the hypothesis that seasonal resistance to CI of grapefruit may be under GR control (85). 


\section{CHAPTER V \\ GENERAL DISCUSSION}

The principal objective of this study was to test a hypothesis (85) that growth regulators (GRs) control resistance of grapefruit to chilling injury (CI). Jacobs (120) discussed 6 rules, all of which should be sustantiated in order for a causal relationship between endogenous activity of GRs and a given biological process to be demonstrated: 1. Parallel variation of $G R$ and process; 2. Excision of the hormonal source; 3. Substiation by exogenous GR; 4. Isolation of the system; 5 . Generality in different plants; 6. Specificity of a given GR. Data presented in previous chapters and other observations in this study have been scrutinized with respect to these rules as follows:

\section{Parallel Variations}

Parallel variation occurred between midseason resistance to $C I$ of conditioned grapefruit and levels of $A B A$ at harvest (Figs. 4, 5). Conditioning-induced CI resistance was also positively correlated with increased levels of $A B A$ (Fig. 11). Monselise and Goren's criticism (177), 
nevertheless, has to be carefully considered in interpreting parallel variations:

The quantification of each component [GR] at a particular time can tell very little about the overall effect of their balance. The very meaning of accumulation of one component is doubtful. Is accumulation the result of a purposeful creation of large amounts of the component needed to elicit the reaction, or of the component not being used in the relation elicited. The main problem is to define cause and effect in a system where we can know very little about the magnitude of time relationships. (177, p: 134)

Zeevaart (295) also suggested turnover rather than total concentration of GRs is important.

Some of the present data did not show parallel

variation, however, between levels of $\mathrm{ABA}$ and $\mathrm{CI}$ resistance:

1. Immature fruit harvested in August were resistant to

CI even when levels of ABA were low (Figs. 4, 5). Mechanisms involved in CI and hence those of resistance to CI of immature and mature grapefruit may differ (198). It is also possible that inhibitors other than $A B A$, such as phenolics, which are abundant in the immature stages of grapefruit (M.A. Ismail, unpublished data), are involved in CI resistance of immature grapefruit; 2 . Addition of ethylene during conditionine increased $A B A$ content but did not increase CI resistance (Fig. 11). Altered ABA metabolism as indicated by build-up of bound $A B A$ (Fig. 11) may be responsible for this lack of parallelism. 


\section{Excision of Hormonal Source}

This rule could not be verified because both detached fruit (Fig. II) and excised flavedo (K. Kawada, unpublished data) are capable of synthesizing $A B A$ and no effective inhibitor for $A B A$ synthesis has been found thus far.

\section{Substitution by Exogenous Hormone}

An additional small scale experiment in 1977 (2 samples/treatment, I carton of 30 fruit/sample) showed a prestorage 50 ppm ABA dip decreased CI of midseason grapefruit, while $500 \mathrm{ppm}, 2,4-\mathrm{D}$ had no effect on CI and 500 ppm $\mathrm{GA}_{3}$ increased CI ( $\mathrm{k}$. Kawada and W. Grierson, unpublished data). Resistance of mature-green tomatoes to CI was also increased by exogenous $\mathrm{ABA}$ and other inhibitors (108).

\section{Isolation of System}

Attempts to use the previously reported tissue culture method for studying CI of grapefruit peel (253) were not successful because CI symptoms (pitting) were not clear.

\section{Generality in Different Plants}

Applied or stress-induced $\mathrm{ABA}$ has been reported to increase resistance to $C I$ of several plant tissues including cotton (207), cucumber (209), bean (286) seedlings and tomatoes (108). 


\section{Specificity of Hormone}

Abscisic acid can be considered as a specific hormone in terms of "stress hormone" (177) but not specifically involved in chilling stress. Instead, Boussba et al. (22) proposed $\mathrm{ABA}$ as a common hormone involved in "cross-adaptation" (91). Rasmussen (203) also suggested ABA may act as a "warning signal" for the plant to protect itself against harmful water stress.

This study provided some confirmation of the hypothesis with implications of some role for $A B A$ but not IAA. The exact role of $\mathrm{ABA}$ or any other endogenous GRs and their possible interactions are yet to be understood.. Study of the effects of $A B A$ on ATPase (103) is particularly suggested for future research on CI resistance inrelation to the energy utilization hypothesis $(253,276)$. The role of $A B A$ in connection with stomatal function is also of interest, for individual stoma appear to be the initial site of pitting due to chilling stress ( $\mathrm{K}$. Kawada, personal observation). 
CHAPTER VI

CONCLUSIONS

1. A useful, reliable and precise high-performance liquid chromatographic method, coupled with isotope dilution, was developed for routine quantitative analyses of IAA and ABA.

2. Florida 'Marsh' grapefruit harvestę biweekly in 197778, 1978-79, and 1979-80 and stored immediately at $5^{\circ} \mathrm{C}$ reached the onset of chilling injury (CI) in about 20 days. Only one or a few pickings in each midseason showed considerable resistance to $\mathrm{CI}$. These results do not support the midseason CI resistance hypothesis for fruit stored immediately after harvest.

3. Postharvest, prestorage conditioning (delayed storage) treatments markedly increased CI resistance of grapefruit in all 3 seasons studied. Experiments in 1978-79 showed a clear second degree polynomial correlation between CI resistance and prestorage weight loss with a maximum resistance at about $3 \%$ weight loss. However, data in 1979-80 showed that a conditioning treatment resulting in no weight loss also increased CI resistance, indicating time delay per se may be important. There was no additional effect from $5 \mathrm{ppm}$ ethylene in 
increasing CI resistance with 3-day conditioning under $29^{\circ} \mathrm{C}$ and $90+\% \mathrm{RH}$.

4. Effectiveness of conditioning treatments was seasonal being greatest in midseason. Thus, conditioned fruit clearly showed the existence of midseascn CI resistance which was not apparent when fruit were stored at $5^{\circ} \mathrm{C}$ immediately after harvest. Seasonal changes in conditioning-induced CI resistance were associated with mean minimum field temperatures for the 30 days preceding harvests.

5. The hypothesis that susceptibility of grapefruit to CI might involve either peel pigments or the plastids containing them is not supported: 1) Immature green fruit harvesied in August were more resistant than those harvested in the fall after color break; 2) Degreening had no effect upon CI resistance.

6. Levels of free IAA in the flavedo were low and did not change appreciably throughout 1977-78 and 1978-79. Distinct seasonal changes in both free and bound ABA levels were observed. Bound $A B A$ in 1977-78 and 1978-79 and free ABA in 1977-78 exhibited only one midseason peak while free $A B A$ in 1978-79 had 3 midseason peaks. Levels of free $\mathrm{ABA}$ increased rapidly soon after cold weather. Generally high levels of ABA in midseason were 
associated with mean minimum field temperatures for the 30 days preceding harvests, and with CI resistance of grapefruit stored after conditioning. Immature grapefruit harvested in August were resistant to CI even when levels of $\mathrm{ABA}$ were low.

7. All postharvest conditioning treatments in 1978-79 increased free ABA levels, the maximum occurring with $2 \%$ weight loss during conditioning. Ethylene at 5 ppm during conditioning increased bound $A B A$ much more than free $A B A$. The pattern of conditioning-induced increase in free $A B A$ levels is positively correlated with that of conditioning-induced CI resistance.

8. This study provided some confirnation of the testing hypothesis that resistance of grapefruit to $\mathrm{CI}$ involves endogenous growth regulators, with implication of some role for $\mathrm{ABA}$. The exact role of $\mathrm{ABA}$ or any other endogenous growth regulators is yet to be understood. 


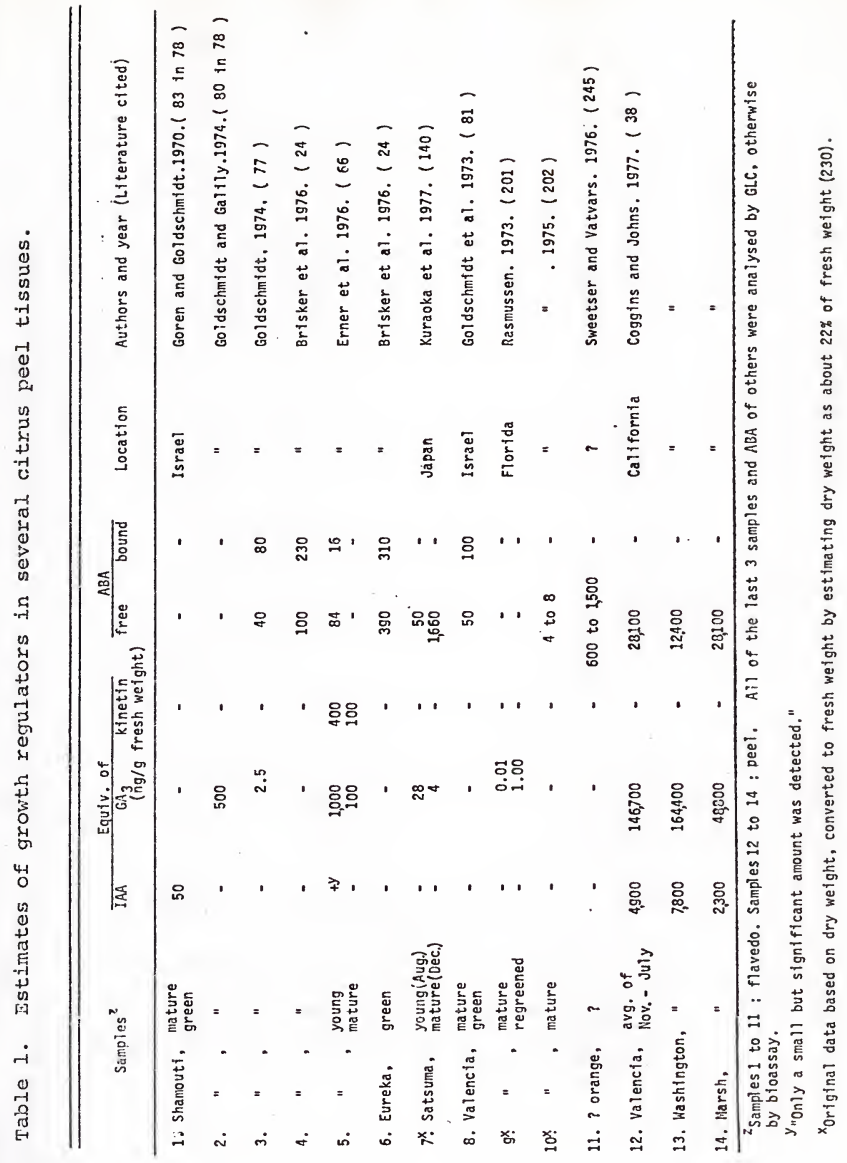


Table 2. Effects of conditioning treatments in 1978-79 on prestorage weight loss and resistance to chilling injury.

$3084-33-4 \sim 20$

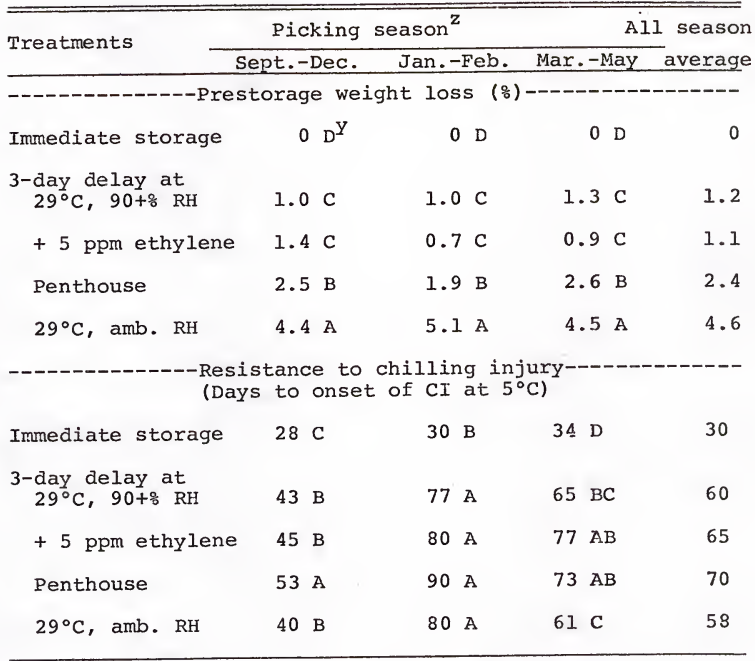

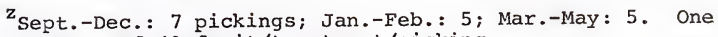
carton of 40 fruit/treatment/picking.

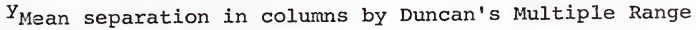
Test, $5 \%$ level. 


\section{EXTRACTION}

Grapefruit Flavedo, $25 \mathrm{~g}$ Fresh Wt.

1. Add ${ }^{14} \mathrm{C}$-ABA \& ${ }^{14} \mathrm{C}$-IAA $\left(2-2.5 \times 10^{4} \mathrm{dpm}\right.$ each, Amersham)

2. Drop into $125 \mathrm{ml}$ boiling $95 \% \mathrm{EtOH}$

3. Chill in an ice bath

4. Homogenize for $2 \mathrm{~min}$

5. Filter with whatman \#1 paper

6. Re-extract solids $3 \times 100 \mathrm{ml} 80 \% \mathrm{EtOH}$

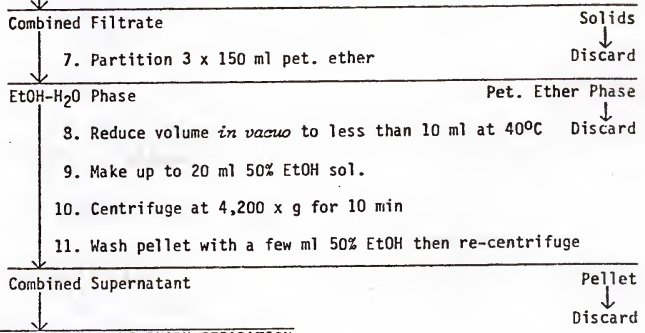

ION-EXCHANGE PRELIMINARY SEPARATION

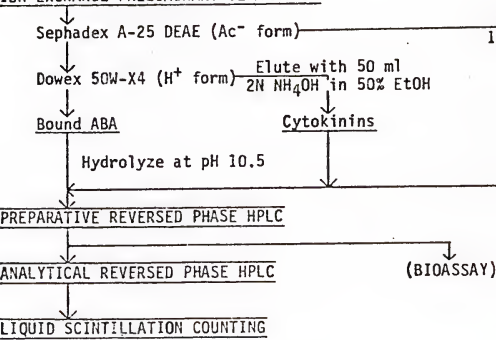


Figure 2-A. Preparative reversed phase HPLC chromatogram of the acidic fraction from a grapefruit peel extract (see Figure 1 ). Zones 1 and 2 were collected for analytical reversed phase HPLC separations of IAA and $A B A$, respectively. (Colunn: Waters $\mu$-Bondapak $\mathrm{C}-18$ ( $300 \times 3.9 \mathrm{~mm})$, column temperature: $30^{\circ} \mathrm{C}$; Mobile phase: linear gradiént at $2 \mathrm{ml} / \mathrm{min}$ from $0.5 \% \mathrm{NH}_{4} \mathrm{OAC}$ (pH 5.1) to $50 \%$ ethanol in $0.5 \% \mathrm{NH}_{4} \mathrm{OAc}$ ( $\left.\mathrm{pH} 5.1\right)^{4}$ in 50 min; detector: UV absorbance at $254 \mathrm{~nm}$ and fluorescence intensity at excitation $290 \mathrm{~nm}$, emission $360 \mathrm{~nm}$.

Figure 2-B. Analytical reversed phase HPLC chromatogram of the IAA zone collected from the preparative HPLC (see Figure 2-A). IAA fraction collected and its radioactivity counted. (Column: Lichrosorb RP-8 (250 x $4.6 \mathrm{~mm})$, mobile phase: isocratic at $2 \mathrm{mn} / \mathrm{min}$ of $2.5 \%$ ethanol in 0.2 \% $\mathrm{NH}_{4} \mathrm{OAC}(\mathrm{pH} 6.5)$, detector: fluorescence intensity at excitation $290 \mathrm{~nm}$, emission $360 \mathrm{~nm}$.

Figure 2-C. Analytical reversed phase HPLC chromatogram of the $A B A$ zone collected from the preparative HPLC (see Figure 2-A). ABA fraction collected and its radioactivity counted. (Column: Lichrosorb RP-8 (250 x $4.6 \mathrm{~mm})$, mobile phase: isocratic at $2 \mathrm{ml} / \mathrm{min}$ of $12.5 \%$ ethanol in $0.2 \% \mathrm{NH}_{4} \mathrm{OAC}(\mathrm{pH} 6.5)$, detector: UV absorbance at $254 \mathrm{~nm}$.) 

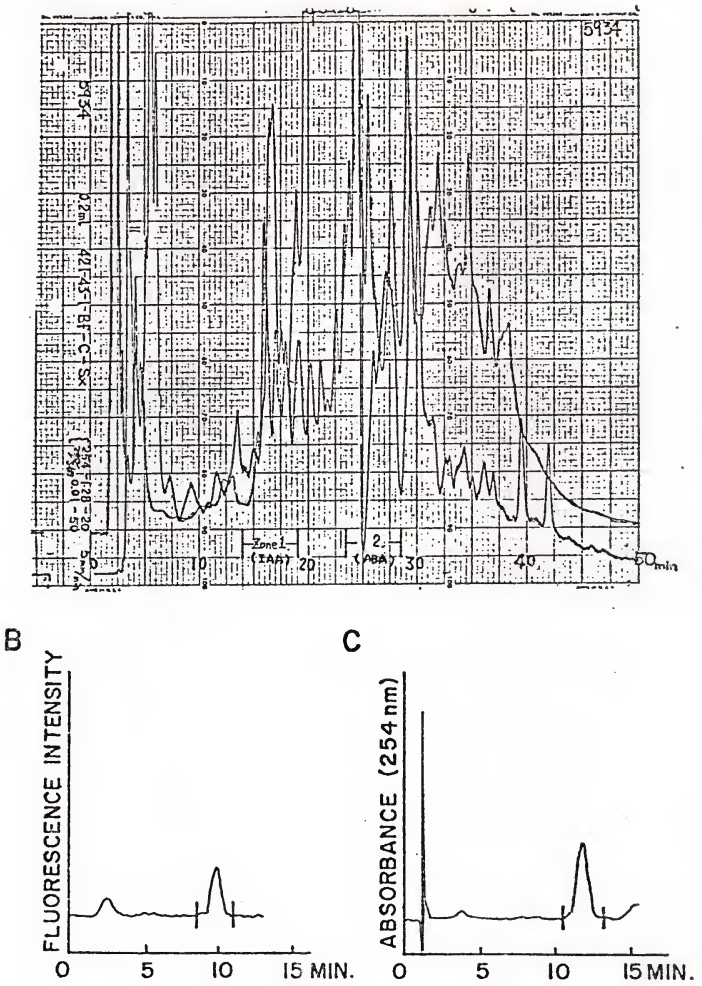
Figure 3-A. Recycling HPLC chromatogram of the ABA fraction collected from analytical HPLC (see Figure 2-C). (Chromatographic conditions were as for Figure 2-C.)

Figure 3-B. Analytical reversed phase HPLC chromatogram of UV light exposed (Chromato-Vue, overnight) $(--)$ or nonexposed (-) ABA fraction collected from the analytical HPLC (see Figure 2-C0). Both ABA and $t-A B A$ fractions were collected and their radioactivity counted. (Chromatographic conditions were as for Figure 2-C.)

Figure 3-C. Stop flow fluorescence spectrum of an IAA peak of analytical HPLC (see Figure 2-B) for a grapefruit peel sample, and authentic IAA (Sigma Chemical Co.) 


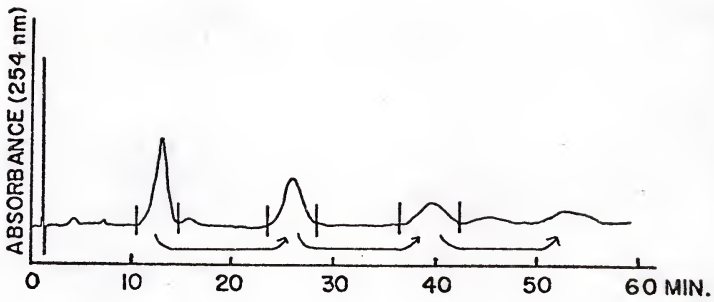

B
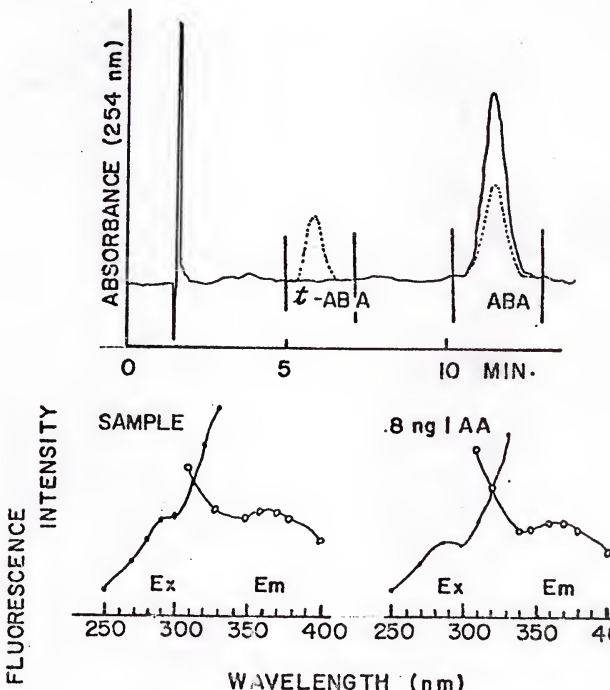

Ex

Em

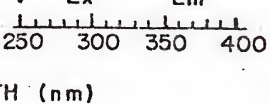

WAVELENGTH $(\mathrm{nm})$ 
Figure 4. 1977-78 changes in: A. Resistance to chilling injury of grapefruit stored at $5^{\circ} \mathrm{C}$ immediately after harvest (immediate storage), after 3-day 5 ppm ethylene treatment at $29^{\circ} \mathrm{C}$ and $90+\%$ relative humidity (delayed storage "A"), after a 3-day holding period in a roof penthouse or in a $38^{\circ} \mathrm{C}$ non-humidity controlled chamber after November (delayed storage "B"); B. Mean ninimum field temperature for 30 days preceding harvests, and peel color; C. Free and bound ABA and free IAA in the flavedo. (A. One carton of 40 fruit/treatment/ picking; B. peel color = average of $15 \mathrm{fruit/picking,}$ 3 readings/fruit; C. average of 2 samples/picking, 10 fruit/sample.) 


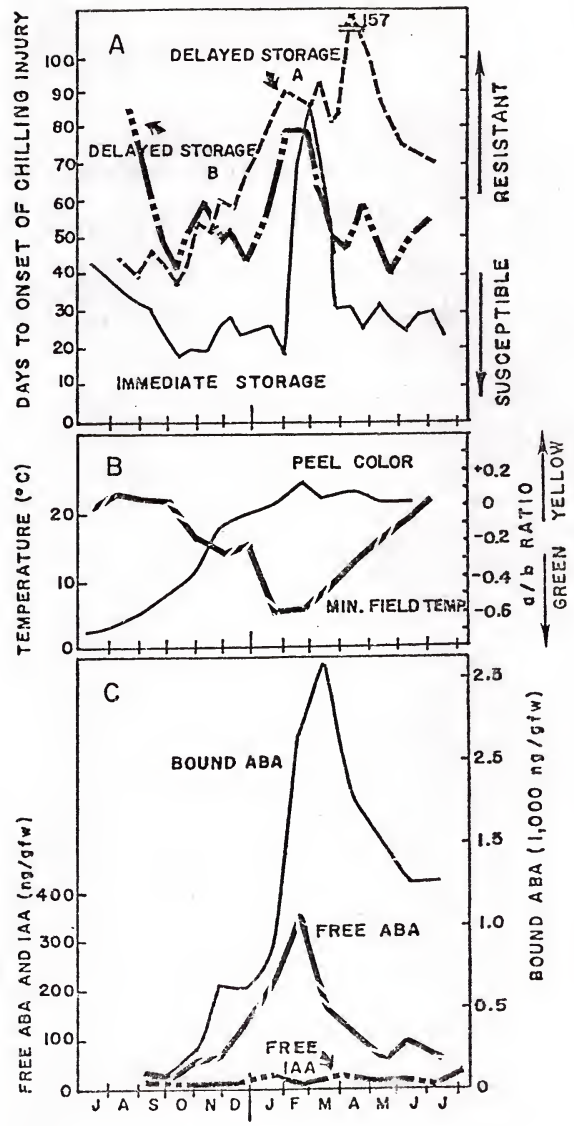


Figure 5. 1978-79 changes in: A. Resistance to chilling injury of grapefruit stored at $5^{\circ} \mathrm{C}$ immediately after harvest or after a 3 -day holding period at $29^{\circ} \mathrm{C}$ and $90+8$ relative humidity; B. Mean minimum field temperature for 30 days preceding harvests, and peel color; $C$. Free and bound $A B A$ and free IAA in the flavedo. (A. One carton of 40 fruit/treatment/picking; $B$. peel color $=$ average of 30 fruit/picking, 3 reading/fruit; c. average of 2 samples/picking, 10 fruit/sample.) 


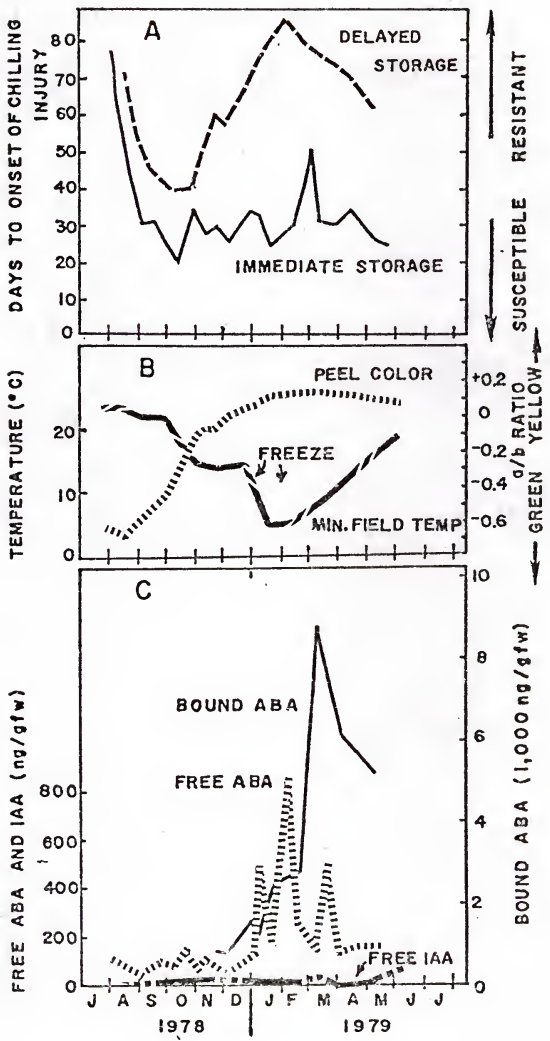




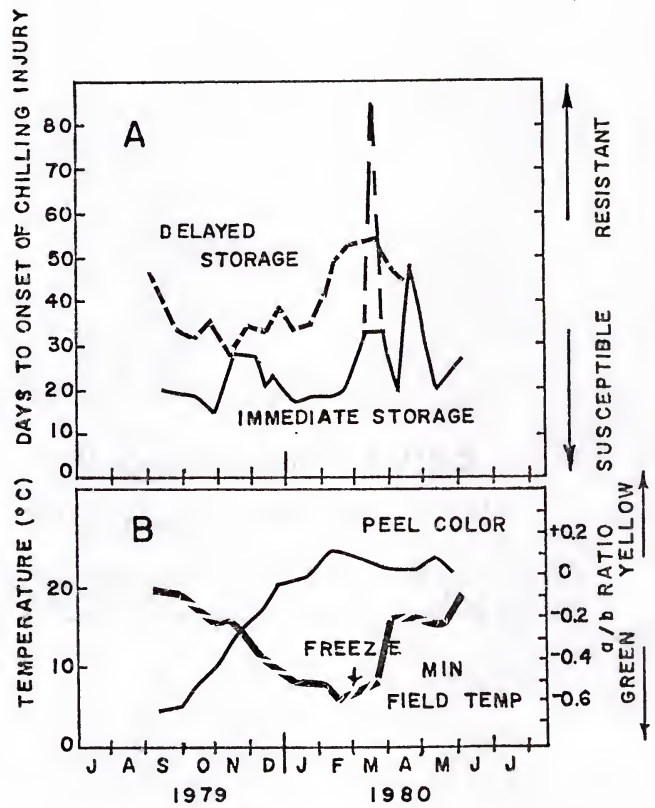

Figure 6. 1979-80 changes in: A. Resistance to chilling injury of grapefruit stored immediately after harvest or after a 3 -day holding period at $29^{\circ} \mathrm{C}$ and $90+\%$ relative humidity/ B. Hean minimum field temperature for 30 days preceding harvests, and peel color. (A. One carton of 40 fruit/treatment/picking; $B$. peel color $=$ average of 30 fruit/picking, 3 readings/ fruit.) 


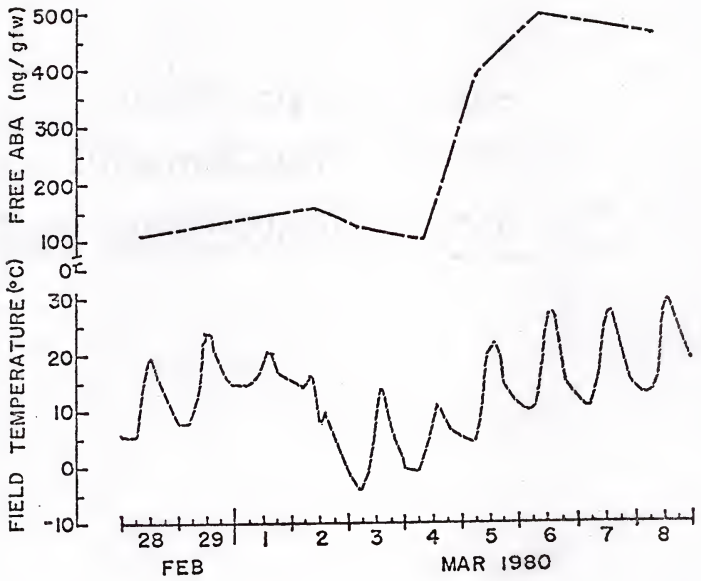

Figure 7. Changes in free $A B A$ levels in the flavedo of grapefruit and field temperature before, during and after the Narch 1980 freeze. (Free ABA = average of 2 samples/ picking, 5 fruit/sample.) 


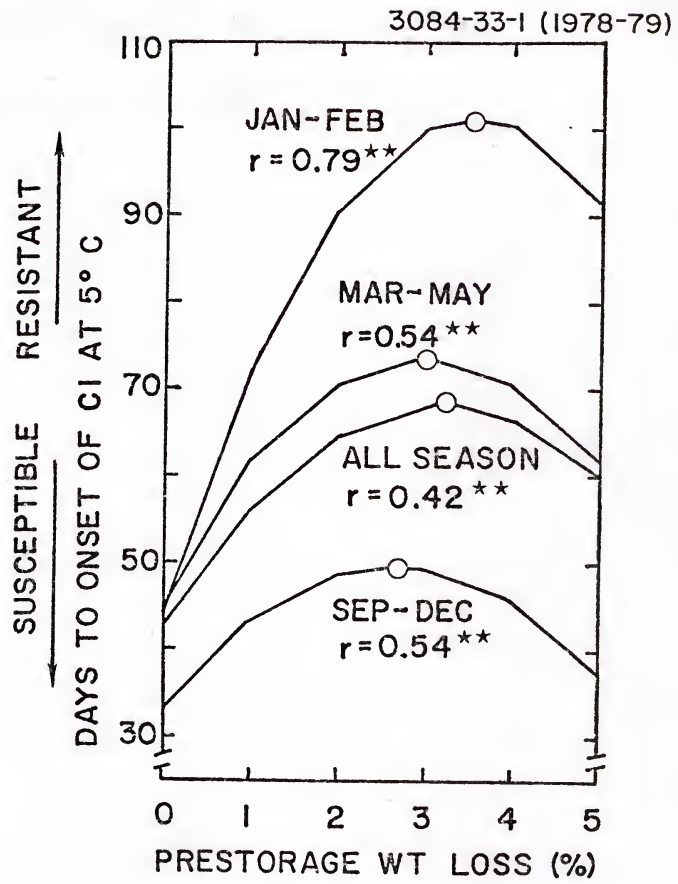

Figure 8. Second degree polynomial correlations between resistance of grapefruit to chilling injury (CI) and prestorage weight loss due to 4 conditioning treatments and an immediate storage treatment (weight loss $0 \%$ ). (Circle under each line indicates the maximurn; September to Decentber, 35; January to February 25; March to May, 25 values.) 


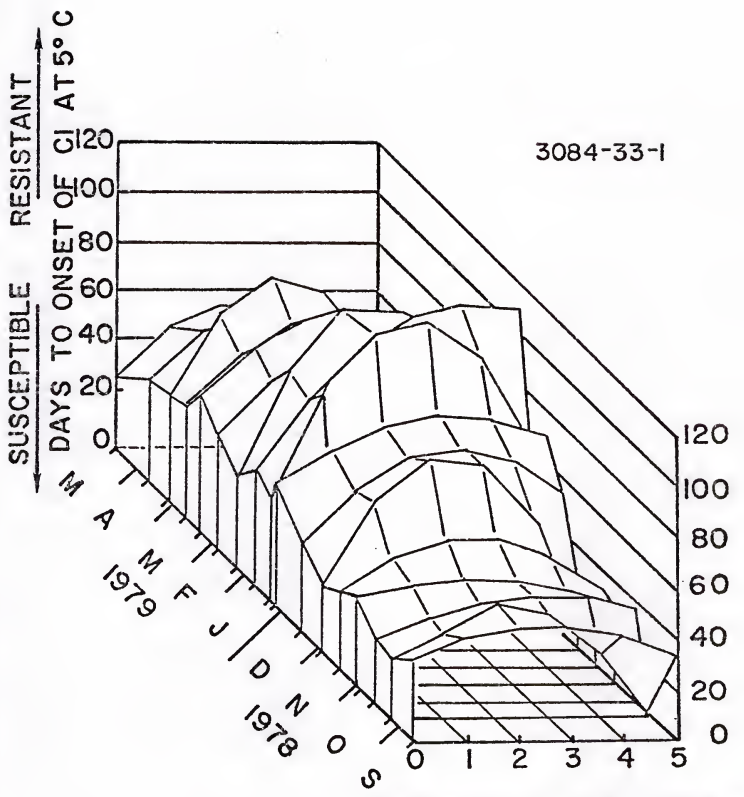

PRESTORAGE WT LOSS (\%)

Figure 9. Seasonal changes in second degree polynomial correlation between resistance of grapefruit to chilling injury (CI) and prestorage weight loss due to 4 conditioning treatments and an imediate storage treatment (weight loss $0 \%$ ) of 17 pickings in 1978-79. (One carton of 40 fruit/treatment/picking.) 
$3084-48-6 \sim 13$

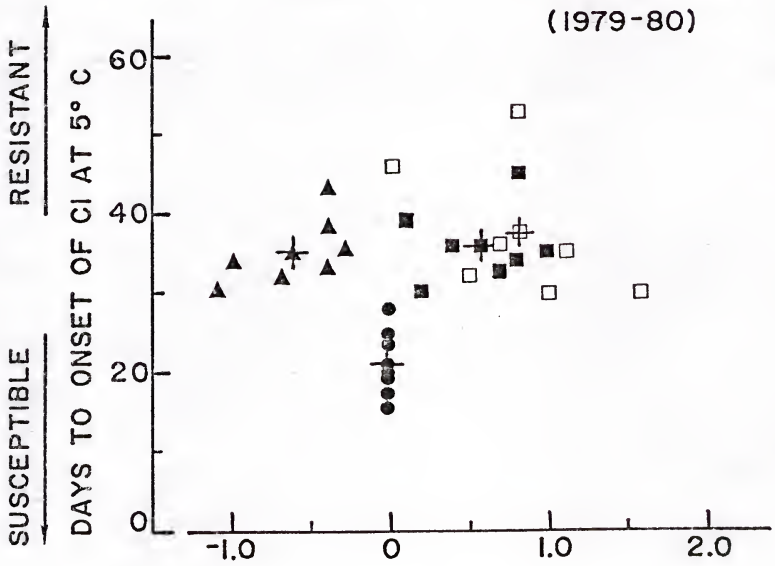

PRESTORAGE WEIGHT LOSS (\%)

Figure 10. Effects of immedaite storage ( ) vs. 3-day conditioning treatments at $29^{\circ} \mathrm{C}$ and $90+8$ relative humidity ( $) ; 29^{\circ} \mathrm{C}$ and $90+\%$ relative humidity with 5 ppm ethylene ( $\square$ ); and $29^{\circ} \mathrm{C}$ and $100 \%$ relative humidity ( $\mathbf{\Delta}$ ) upon prestorage weight loss and resistance of grapefruit to chilling injury (CI). (Eight pickings between November 26, 1979, and February 18, 1980; one carton of 40 fruit/ treatment/picking; corsses indicate mean of each treatment.) 
$421-80-8,9,10$

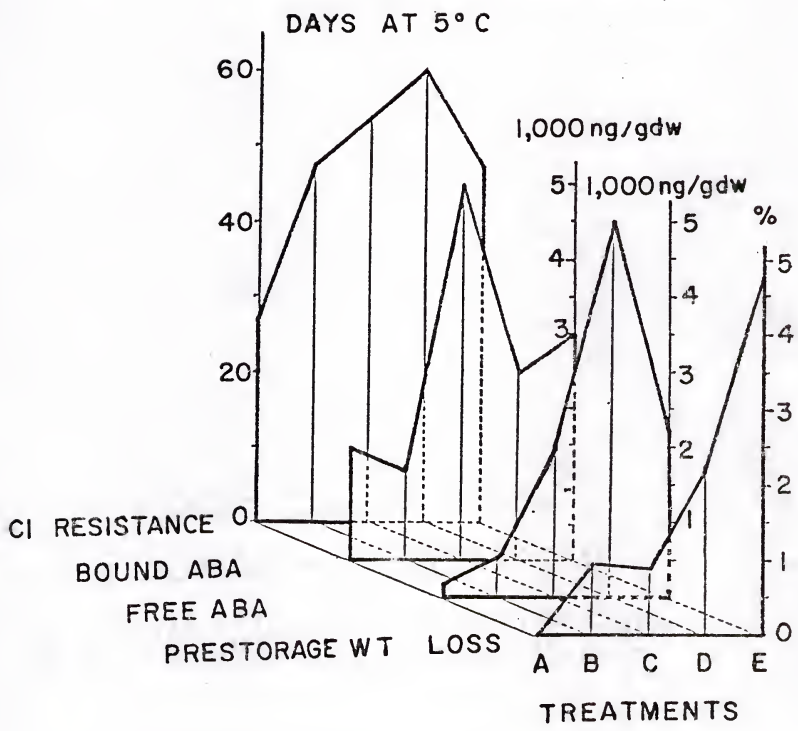

Figure 11. Effects of inmediate storage vs. four 3-day conditioning treatments on prestorage weight loss, free and bound $A B A$ levels in the flavedo, and resistance of grapefruit to chilling injury (CI). Treatment A: immediate storage; $\mathrm{B}$ : at $29^{\circ} \mathrm{C}$ and $90+\%$ relative humidity; C: $29^{\circ} \mathrm{C}$ and $90+\frac{\circ}{0}$ relative humidity with 5 ppm ethylene; D: in a roof penthouse; E: $27^{\circ} \mathrm{C}$ and ambient humidity. (Values are averages of 3 pickings during November and December, 1978. Resistance to $\mathrm{CI}$ and weight loss: one carton of 40 fruit/treatment/picking. Levels of ABA: 2 samples/picking.) 
1. Abdel-Maksoud, M.M., A.B. Abou Aziz, A.S. Abdel-Kader, and K.A. Abdel-Samie. 1974. Influence of growing season and storage temperature on chilling injury of tomato fruit. Egypt. J. Hort. I(2):171-177.

2. Abdel-Rahman, M. 1977. Patterns of hormones, respiration and ripening enzymes during development, maturation and ripening of cherry tomato fruits. Physiol. Plant. 39:115-118.

3. Abe, K., K. Chachin, and K. Ogata. 1976. Chilling injury in eggplant fruits. II. The effects of maturation and harvesting season on pitting injury and browning of seeds and pulp during storage. J. Japan. Soc. Hort. Sci. $45(3): 307-312$.

4. Abeles, F.B. 1973. Ethylene in plant biology. Academic Press, New York, N.Y.

5. Ackerson, R.C. 1980. Stomatal response of cotton to water stress and abscisic acid as affected by water stress history. Plant Physiol. 65:455-459.

6. Adato, I., S. Gaxit, and A. Blumenfeld. 1976. Relationship between changes in abscisic acid and ethylene production during ripening of avocado fruits. Aust. J. Plant Physiol. 3:555-558.

7. Adesomoju, A.A., J.I. Kokgun, D.E.U. Ebong, and P. Gaskin. 1980. GC-MS identification of abscisic acid and abscisic acid metabolites in seed of Vigna unguiculata. Phytochemistry 19:223-225.

8. Alden, J. and R.K. Hermann. 1971. Aspects of the coldhardiness mechanism in plants. Bot. Rev. 31:37-142.

9. Alvim, R., E.W. Hewett, and P.F. Saunders. 1976. Seasonal variation in the hormone content of willow. $I$. Changes in abscisic acid content and cytokinin activity in xylem sap. Plant Physiol. 57:474-476.

10. Apeland, J. 1961. Factors effecting [sic] the keeping qualities of cucumbers. Int. Inst. Refrig. Suppl. $1: 45-48$. 
11. Apeland, J. 1966. Factors affecting the sensitivity of cucumbers to chilling temperatures. Int. Inst. Refrig. Bul. 46, Annexe 1:324-333.

12. Apeland, J. 1966. Factors affecting non-parasitic disorders of the harvested product of cucumber. Acta Hort. 4:102-104.

13. Arteca, R.N., B.W. Poovaiah, and O.E. Smith. 1980. Use of high performance liquid chromatography for the determination of endogenous hormone levels in Solanum tuberosum I. subjected to carbon dioxide enrichment of the root zone. Plant Physiol. $65: 1216-1219$.

14. Atkin, R.K., G.E. Barton, and D.K. Robinson. 1973. Effect of root-growing temperature on growth substances in xylem exudate of Zea mays. J. Expt. Bot. $24: 475-487$.

15. Aung, L.J., A.A. DeHertogh, and G. Staby. 1969. Temperature regulation of endogenous gibberellin activity and development of Tulipa gesneriana $L$. Plant Physiol. 44:403-406.

I6. Avigdori-Aviđov, H. 1977. Involvement of endogenous gibberellins in the chilling requirements of strawberry (Fragaria ananassa Duch.). Ann. Bot. $41: 927-936$.

17. Bates, G.R. 1936. Storage tests with Rhodesian oranges during 1934. Brit. S. Africa Co.', Mazoe Citrus Expt. Sta. Pub. 4b. (Read in C.W. Wardlaw. 1937. Storage and transport of tropical fruits and vegetables; Citrus. Tropical Agx. (Trinidad), 16:131139, 163-170.)

18. Bates, G.R. 193\%. Report of the plant pathologist for the year ending December 31, 1936. Ann. Rept. Brit. Co., Mazoe Citrus Expt. Sta. 1936:157-167. (Read Chem. Abst. 34, column 6004. 1940.)

19. Bellandi, D.M. and K. Dörffling. 1974. Transport of abscisic acid 2-C-14 in intact pea seedlings. Physiol. Plant. 32:365-368.

20. Bolduc, R.J., J.H. Cherry, and B.O. Blair. 1970. Increase in indoleacetic acid oxidase activity of winter wheat by cold treatment and gibberellic acid. Plant Physiol. 45:461-464. 
21. Bornman, C.H. and E. Jansson. 1980. Nicotiana tabacum callus studies. $x$. ABA increases resistance to cold damage. Physiol. Plant. 48:491-493.

22. Boussba, S.; A. Rikin, and A.E. Richmond. 1975. The role of abscisic acid in cross-adaptation of tobacco plants. Plant Physiol. 56:337-339.

23. Brenner, M.L. 1978. Use of modern forms of chromatography for plant growth substance analyses. II. Proc. Plant Growth Regulator Working Group 1978:20-32.

24. Brisker, H.E., E.E. Goldschmidt, and R. Goren. 1976. Ethylene-induced formation of $A B A$ in citrus peel as related to chloroplast transformations. plant Physiol. 58:377-379.

25. Brooks, C., J.S. Cooley, and D.F. Fisher. 1919. Nature and control of apple-scald. J.Agr. Res. 18:211-240.

26. Brooks, C. and C.P. Harley. 1937. Soft scald and soggy break-down of apples. J. Agr. Res. 49:55-69.

27. Brooks, C. and L.P. McColloch. 1936. Some storage diseases of grapefruit. J. Agr. Res. 52:319-351.

28. Browning, G. and P.F. Saunders. 1977. Membrane localized gibberellins $A_{9}$ and $A_{4}$ in wheat chloroplasts. Nature 265:375-377.

29. Cargile, N.L., R. Borchert, and J.D. McChesney. 1979. Analysis of abscisic acid by high-performance liquid chromatography. Anal. Biochem. 97:331-339.

30. Chace, W.G., P.L. Harding, J.J. Smoot, and R.H. Cubbedge. 1966. Factors affecting the quality of grapefruit exported from Florida. U.S. Dept. Agr. Mrktg. Res. Rept. 739.

31. Chalutz, E., S. Biron, and E. Alumot. 1973. Thiabendazole reduction of ethylene dibromide peel injury on citrus fruits. Proc. Symp. Int. Inst. Refrig. Comm. C2, Jerusalem, Israel. p. 205-209.

32. Chen, P.M. and P.H. Li. 1977. Induction of frost hardiness in stem cortical tissues of Cornus stolonifera Michx. by water stress. II. Biochemical changes. Plant Physiol. 59:240-243. 
33. Chen, H.H. and P.H. Li. 1978. Interactions of low temperature, water stress, and short days in the induction of stem frost hardiness in red osier dogwood. Plant Physiol. 62:833-835.

34. Chia, A.J., M.L. Brenner, and W.A. Brun. 1977. Rapid separation and quantification of abscisic acid from plant tissues using high performance liquid chromatography. Plant Physiol. 59:821-826.

35. Christiansen, M.N. 1979. Physiological bases for resistance to chilling. HortScience 14:583-586.

36. Christiansen, M.N. and E.N. Ashworth. 1978. Prevention of chilling injury to seedling cotton with anti-transpirants. Crop Sci. 18:907-908.

37. Coggins, C.J., Jr., H.z. Hield, and R.M. Burns. 1962. The influence of potassium gibberellate on grapefruit trees and fruit. Proc. Amer. Soc. Hort. Sci. 81:221-226.

38. Coggins, C.W., Jr. and W.W. Jones. 1977. Growth regulators and coloring of citrus fruits. Proc. Int. Soc. Citriculture 2:686-688.

39. Coggins, C.W., Jr. and L.N. Lewis. 1962. Regreening of 'Valencia' orange as influenced by potassium gibberellate. plant physiol. 37:625-627.

40. Cohen, D. 1975. Hormonal responses to environmental stress: A review. Proc. Agron. Soc. New Zealand $5: 55-57$.

41. Cooke, R.J., P.F. Saunders, and R.E. Kendrick. 1975. Red light induced production of gibberellin-like substances in homogenates of etiolated wheat leaves and in suspensions of intact etioplasts. planta (Berl.) 124:319-328.

42. Coombe, B.G. and C.R. Hale. 1973. The hormone content of ripening grape berries and the effects of growth substance treitments. plant Physiol. $51: 629-635$.

43. Cooper, W.C., G.K. Rasmussen, B.J. Rogers, P.C. Reece, and W.H. Henry. 1968. Control of abscission in agricultural crops and its physiological basis. plant Physiol. 43:1560-1576. 
44. Cooper, W.C., G.K. Rasmussen, and J.J. Smoot. 1968. Induction of degreening of tangerines by preharvest applications of ascorbic acid and other ethylenereleasing agents. $\quad$ Citrus Ind. 49 (Oct.): 25-27.

45. Cooper, W.C., G.K. Rasmussen, and E.S. Waldon. 1969. Ethylene evolution stimulated by chilling in Citrus and Persea sp. Plant Physiol. 44:1194-1196.

46. Cooper, W.C., R.H. Young, and W.H. Henry. 1969. Effect of growth regulators on bud growth and dormancy in citrus as influenced by season of year and climate. Proc. First Int. Citrus symp. 1:301-314.

47. Cox, W. and J. Levitt. 1976. Interrelations between environmental factors and freezing resistance of cabbage leaves. Plant Physiol. 57:553-555.

48. Crozier, A., J.B. Zaerr, and R.O. Morris. 1979. Fluorescence detection of plant hormones at the picogram level using high performance liquid chromatography. Abst. loth Int. Conf. Plant Growth Substances, Madison, WI. p. 52, no. 755. (Abst.)

49. Darbyshire, B. 1971. Changes in indoleacetic acid oxidase activity assocaited with plant water potential. Physiol. Plant. 25:80-84.

50. Davenport, T.L., W.R. Jordan and P.W. Morgan. 1977. Movement and endogenous levels of abscisic acid during water-stress-induced abscission in cotton seedlings. Plant Physiol. 59:1165-1168.

51. Davies, R. and W.W. Boyes. 1936. The effect of temperature of storage, wilting and delayed storage on pitting of grapefruit. Ann. Rept. So. Africa Dept. Agr. and Forest., Low Temp. Res. Lab. (Capetown) 1934-35:161-163.

52. Davison, R.M., R.M. Rudnicki, and M.J. Bukovac. 1976 . Endogenous plant growth substances in developing fruit of Prunus cerasus L. V. Changes in inhibitor (ABA) levels in the seed and pericarp. J. Amer. Soc. Hort. Sci. 101:519-523.

53. De la Roche, I.A., C.J. Andrews., M.K. Pomeroy, P. Weinberger, and $M$. Kates. 1972. Lipid changes in winter wheat seedlings (Triticum aesticum) at temperatures inducing cold hardiness. Can. J. Bot. $50: 2401-2409$. 
54. Dennis, F.G., Jr. 1977. Growth hormones: Pool size, diffusion, or metabolism? HortScience 12:217-220.

55. DeYoe, D.R. and J.B. Zaerr. 1976. An improved method for extraction of indole-3-acetic acid from shoots of Douglas fir. Can. J. For. Res. 6:429-435.

56. Dilley, D.R. 1969. Hormonal control of fruit ripening. HortScience $4: 111-114$.

57. Downton, W.J.S. and B.R. Loveys. 1978. Compositional changes during grape berry development in relation to abscisic acid and salinity. Aust. J. Plant Physiol. 5:415-423.

58. Dumbroff, E.B., D.B. Cohen, and D.P. Webb. 1979. Seasonal levels of abscisic acid in buds and stems of Acer saccharum. Physiol. Plant. 45:211-214.

59. During, H. 1978. Studies on hormonal control of ripening in berries of grape vines. Acta Hort. $80: 397-405$.

60. Durley, R.C., T. Kannangara, and G.M. Simpson. 1978. Analysis of abscisins and 3-indolylacetic acid in leaves of Sorghum bicolor by high performance liquid chromatography. Can. J. Bot. 56:157-161.

61. Eagles, C.G. and P.F. Wareing. 1964. The role of growth substances in the regulation of bud dormancy. Plant Physiol. 17:697-708.

62. Eaks, I.L. 1952. The post-harvest physiology of cucumbers (Cucumis sativus L.) and summer squash (Cucurbita pepo L.) at chilling and non-chilling temperatures. Ph.D. Dissertation, Univ. of California, Davis, CA. 137 p.

63. Eask, I.L. 1975. Effect of chilling on the respiration of oranges and lemons. Proc. Amer. Soc. Hort. Sci. $87: 181-186$.

64. El-Zeftawi, B.M. and R.G. Garrett. 1978. Effects of ethephon, GA and light exclusion on rind pigments, plastid ultrastructure and juice quality of 'Valencia' oranges. J. Hort. Sci. 53:215-223.

65. Environmental Protection Agency. 1977. Rebuttable presumption against registration and continued registration of pesticide products containing ethylene dibromide (EDB). Federal Register 42(240): 63134-63148. December 14 . 
66. Erner, Y., R. Goren, and S.P. Monselise. 1976. The rough fruit condition of the 'Shamouti' orange. Connections with the endogenous hormonal balance. J. Hort. Sci. 51:367-374.

67. Eugene, A.M. and F.G. Dennis, Jr. 1978. Hormonal control of flower bud dormancy in sour cherry (Prunus cerasus L.). III. Effects of leaves, defoliation and temperature on levels of abscisic acid in flower primordia. J. Amer. Soc. Hort. Sci. 103:446-449.

68. Fairchild, G.F. 1979. Estimated Florida orange, 'Temple' and grapefruit production, 1979-80 through 1984-85. Economic Res. Dept. Rept. CIR 79-1, Fla. Dept. Citrus.

69. Forycka, D., W. Gajowniczek, and A. Kacperska-Palacz. 1978. Changes in growth regulators during plants [sic] acclimation to winger conditions. Acta Hort. 81:77-84.

70. Frankland, B. and P.F. Wareing. 1966. Hormonal regulation of seed dormancy in hazel (Corylus avellana L.) and beech (Fagus sylvatica L.). J. Expt. Bot. 17:596-611.

71. Friend, W.H. and W.J. Bach. 1932. Storage experiments with Texas citrus fruit. Tex. Agr. Expt. Sta. Bul. 446 .

72. Fuchs, Y. and E. Gertman. 1974. Insoluble antibody column for isolation and quantitative determination of gibberellins. plant \&.. Cell physiol. $15: 629-633$.

73. Galston, A.W. and L. Dalberg. 1954. The adaptive formation and physiological significance of indoleacetic acid oxidase. Amer. J. Bot. 4l:373-380.

74. Gerloff, E.D., T. Richardson, and M.A. Stahmann. 1966. Changes in fatty acids of alfalfa roots during cold hardening. Plant Physiol. 41:1280-1284.

75. Gertman, E. and Y. Fuchs. 1972. Effect of abscisic acid and its interactions with other plant hormones on ethylene production in two plant systems. plant Physiol. 50:194-195. 
76. Glenn, J.L., C.C. Kuo, R.C. Durley, and R.P. Pharis. 1972. Use of insoluble polyvinylpyrrolidone for purification of plant extracts and chromatography of plant hormones. Phytochemistry 11:345-351.

77. Goldschmidt, E.E. 1974. Hormonal and molecular regulation of chloroplast senescence in citrus peel. p. 1027-1033. In Plant growth substances 1973. (Proc. 8th Int. Conf. Plant Growth Substances.) Hirokawa Publishing Co., Tokyo.

78. Goldschmidt, E.E. 1976. Endogenous growth substances of citrus tissues. Hortscience 11:95-99.

79. Goldschmidt, E.E., S.K. Eilati, and R. Goren. 1972. Increase in ABA-like growth inhibitors and decrease in gibberellin-like substances during ripening and senescence of citrus fruits. p. 611617. In D.J. Carr (ed.) Plant growth substances 1970. Springer-Verlag, Berlin.

80. Goldschmidt, E.E. and D. Galily. 1974. The fate of endogenous gibberellins and applied radioactive gibberellin $A_{3}$ during natural and ethylene-induced senescence in citrus peel. Plant \& Cell Physiol. $15: 485-491$.

81. Goldschmidt, E.E., R. Goren, Z. Even-Chen, and S. Bittner. 1973. Increase in free and bound abscisic acid during natural and ethylene-induced senescence of citrus fruit peel. Plant Physiol. $51: 879-882$.

82. Goldschmidt, E.E. R. Goren, S.P. Monselise, N. Takahashi, H. Igoshi, I Yamaguchi, and K. Hirose. 1971.

Auxins in Citrus: A reappraisal. Science 174: 1256-1257.

83. Goren, R. and E.E. Goldschmidt. 1970. Regulative systems in the developing citrus fruit. I. The hormonal balance in orange fruit tissues. Physiol. Plant. 23:937-947.

84. Grierson, w. 1971. Chisling injury in tropical and subtropical fruits: IV. The role of packaging and waxing in minimizing chilling injury of grapefruit. Proc. Irop. Reg., Amer. Soc. Hoxt. Sci. 15:76-88.

85. Grierson, w. 1974. Chilling injury in tropical and subtropical fruits: V. Effect of harvest date, degreening, delayed storage and peel color on chilling injury of grapefruit. Proc. Trop. Reg., Amer. Soc. Hort. Sci. 18:66-73. 
86. Grierson, W. 1975. Chilling injury of fruits and vegetables. p. 27-39. In Proc. 1st Conf. on Preservation of Fresh vegetables and Fruits., Univ. Nacional de Mexico.

87. Grierson, พ. and T.T. Hatton. 1977. Factors involved in storage of citrus fruits: A new evaluation. Proc. Int. Soc. Citriculture 1:227-231.

88. Guinn, G. 1971. Changes in sugars, starch, RNA, protein, and lipid-soluble phosphate in leaves of cotton plants at low temperatures. Crop Sci. 11:262-265.

89. Haard, N.F. 1973. Chilling injury of green banana fruit: Kinetic anomolies of IAA oxidase at chilling temperatures. J. Food Sci. 38:907-908.

90. Haard, N.F. and D. Timbie. 1973. Chilling injury in green banana fruit: Changes in peroxidase isozymes in soluble and particulate pools. J. Food Sci. $38: 642-645$.

91. Hale, H.B. 1969. Cross-adaptation. Environ. Res. $2: 423-434$.

92. Harding, P.L., M.J. Soule, Jr., and M.B. Sunday. 1957. Storage studies on 'Marsh' grapefruit. 1955-56 season. I. Effect of nitrogen and potash fertilization on keeping quality. II. Effect of different temperature combinations on keeping quality. U.S. Dept. Agr., Agr. Mktg. Serv. 202.

93. Harding, P.L., M.B. Sunday, and H.W. Hruschka, 1952. The effect of prestorage treatments and storage temperatures on the keeping quality of Florida grapefruit at Orlando, Florida, and New York City, N.Y., 1952. U.S. Dept. Agr., H.T. and S. Office Rept. 285 .

94. Harvey, E.M. and G.L. Rygg. 1936. Field and storage studies on changes in the composition of the rind of the 'Marsh' grapefruit in California. J. Agr. Res. 52:747-787.

95. Hatton, T.T., Jr., and R.H. Cubbedge. 1973. Influence of ethylene on stored late-season 'Marsh' grapefruit. Hortscience $8: 101-102$.

96. Hatton, T.T. and R.H. Cubbedge. 1974. Influence of initial carbon dioxide exposure on stored early-, mid- and late-season 'Marsh' grapefruit. Proc. Fla. State. Hort. Soc. 87:227-230. 
97. Hatton, T.T. and R.H. Cubbedge. 1975. Disorders caused by ethylene in stored 'Marsh' grapefruit harvested during autumn, winter, and spring. 14th Int. Cong. Refrig. C 2-95:1-12 (Hoscow).

98. Hatton, T.T. and R.H. Cubbedge. 1977. Effects of prestorage carbon dioxide treatments and delayed storage on stem-end rind breakdown of 'Marsh' grapefruit. HortScience 12:120-121.

99. Hatton, T.T., R.H. Cubbedge, and W. Grierson. 1975. Effects of prestorage carbon dioxide treatments and delayed storage on chilling injury of 'Marsh' grapefruit. Proc. Fla. State Hort. Soc. 88:335-338.

100. Hatton, T.T., Jr. and W.F. Reeder. 1967. Quality of 'Persian' limes after different packinghouse treatment and storage in various controlled atmospheres. Proc. Trop. Reg., Amer. Soc. Hort. Sci. $11: 23-32$.

101. Hatton, T.T., J.J. Smoot, and R.H. Cubbedge. 1972. Influence of carbon dioxide exposure on stored mid- and late-season 'Marsh' grapefruit. Proc. Trop. Reg., Amer. Soc. Hort. Sci. 16:49-58.

102. Hawkins, L.A. 1921. A physiological study of grapefruit ripening and storage. J.Agr. Res. 22:263-279.

103. Hawkins, L.A. and W.R. Barger. 1926. Cold storage of Florida grapefruit. U.S. Dept. Agr. Bul. 1368 .

104. Hillman, J.R. 1978. Isolation of plant growth substances. Cambridge Univ. Press, New York, N.Y.

105. Hoad, G.V. 1978. Effect of water stress on abscisic acid levels in white lupin (Lupinus albus L.) fruit, leaves and phloem exudate. planta 142: 287-290.

106. Holubowicz, T. and A.A. Boe. 1969. Development of cold hardiness in apple seedlings treated with gibberellic acid an $\hat{\lambda}$ abscisic acid. J. Amer. Soc. Hort. Sci. 94:661-654.

107. Howell, G.S. and C.J. Weiser. 1970. The environmental control of cold accimation in apple. Plant physiol. $45: 390-394$.

108. Huang, L. 1977. Effects of chemicals on the chilling injury of detached fruits. (1) Chemical control on the chilling injury of detached tomatoes. J. Chin. Soc. Hort. Sci. 23:180-191. 
109. Huang, L.S. and C.H. Peng. 1977. Effects of chemical treatments on the chilling injury of detached banana fruit. J. Chin. Soc. Hort. Sci. 23:23-31.

110. Hubick, K.T. and D.M. Reid. 1980. A rapid method for the extraction and analysis of abscisic acid from plant tissue. Plant Physiol. 65:523-525.

111. Hyodo, H. 1977. Ethylene production and respiration of 'Satsuma' mandarin (Citrus unshiu Marc.) fruit harvested at different stages of development. J. Japan. Soc. Hort. Sci. 45:427-432.

112. Hyodo, H., H. Kuroda, and S.F. Yang. 1978. Introduction of phenylalanine ammonia-lyase and increase in phenolics in lettuce leaves in relation to the development of russet spotting by ethylene. Plant Physiol. 62:31-35.

113. Ilker, Y. 1976. Physiological manifestation of chilling injury and its alleviation in okra fruits (Abelmoschus esculentus (L.) Moench). Ph.D. Dissertation, Univ. of California, Davis, CA. 203 p.

114. Inaba, A., M. Ishida, and Y. Sobajima. 1976. Changes in endogenous hormone concentrations during berry development in relation to the ripening of Delaware grapes. J. Japan. Soc. Hort. Sci. $45: 245-252$.

115. Irving, R.M. 1969. Characterization and role of an endogenous inhibitor in the induction of cold hardiness in Acer negundo. Plant Physiol. 44:801-805.

116. Irving, R.M. and F.O. Lanphear. 1968. Regulation of cold hardiness in Acer negundo. Plant Physiol. $43: 9-13$.

117. Ismail, M.A. and G.E. Brown. 1975. Phenolic content during healing of 'Valencia' orange peel under high humidity. J. Amer. Soc. Hort. Sci. 100:249-251.

118. Ismail, M.A. and W. Grierson. 1977. Seasonal susceptibility of grapefruit to chilling injury as modified by certain growth regulators. Hortscience $12: 118-120$.

119. Iwata, T., K. Nakagawa, and K. Ogata. 1968. Physiological studies of chilling injury in natsudaidai (Citrus natsudaidai Hayata) fruits. II. J. Jap. Soc. Hort. Sci. 28:93-100. 
120. Jacobs, W.P. 1959. What substance normally controls a given biological process? I. Formulation of some rules. Develop. Biol. 1:527-533.

121. Johnson, H.B., W.R. Buford, and A.L. Ryall. 1951. Storage tests on Florida and Texas grapefruit, 1950. U.S. Dept. Agr., H.T. and S. Office Rept. 237.

122. Jones, M.G., J.D. Metzger, and J.A.D. Zeevaart. 1980. Fractionation of gibberellins in plant extracts by reverse phase high performance liquid chromatography. Plant Physiol. 65:218-221.

123. Jones, R.I. 1968. Aqueous extraction of gibberellins from pea. Planta (Berl.) 81:97-105.

124. Jones, R.L. 1973. Gibberellins: Their physiological role. Ann. Rev. Plant Physiol. 24:571-598.

125. Jones, W.W., C.W. Coggins, Jr., and T.W. Embleton. 1977. Growth regulators and alternate bearing. proc. Int. Soc. Citriculture 2:657-660.

126. Kacperska-Palacz, A. 1978. Mechanism of cold acclimation in herbaceous plants. p. 139-152. In P.H. $\mathrm{Li}$ and $\mathrm{A}$. Sakai (eds.) Plant cold hardiness and freezing stress: Mechanisms and crop implications. Academic Press, New York, N.Y.

127. Kader, A.A., J.M. Lyons, and L.L. Morris. 1974. Postharvest responses of vegetables to preharvest field temperature. Hortscience $9(6): 523-527$.

128. Kamisaka, S. and P. Larsen. 1977. Improvement of the indolo- $\propto$-pyrone fluorescence method for quantitative determination of endogenous indole-3-acetic acid in lettuce seedlings. Plant \& Cell Physiol. 18:595-602.

129. Karbassi, P., L.A. Garrard, and S.H. West. 1971. Reversal of low temperature effects on a tropical plant by gibberelli= acid. Crop Sci. 11:755-757.

130. Kasamo, K. 1979. Effect of abscisic acid on membranebound epidermal ATPase from tobacco leaves. Plant \& Cell Physiol. 2C:293-300.

131. Kawada, K. and L.G. Albrigo. 1979. Effects of film packaging, in-carton air filters, and storage temperatures on the keeping quality of Florida grapefruit. Proc. Fla. State Hort. Soc. 92:209-212. 
132. Kawada, K., W. Grierson, and J. Soule. 1978. Seasonal resistance to chilling injury of 'Marsh' grapefruit as related to winter field temperature. Proc. Fla. State Hort. Soc. 91:128-130.

133. Khan, A.A. 1975. Primary, preventive and permissive roles of hormones in plant systems. Bot. Rev. $41: 391-420$.

134. Kidd, F. and C. West. 1933. Low-temperature tolerance of summer and autumn-grown hot-house tomatoes. Gt. Brit. D.S.I.R. Food Invest. Board. Spec. Rept. 1932:82-83.

135. Kitagawa, H., T. Tarutani, and K. Kawada. 1979. Studies on storage of Citrus hassaku: II. Effects of thiabendazole. Abst. Jap. Soc. Hort. Sci. S-54 Fall Meeting. Abst. No. 28 .

136. Kokkalos, T.I. 1974. Thiabendazole reduces chilling injury (pitting) of Cyprus-grown grapefruit. Hortscience $9: 456-457$.

137. Kosiyachinda, S. and H.E. Young. 1976. Chilling injury of avocado fruit at different stages of the respiratory climacteric. J. Amer. Soc. Hort. Sci. 101:665-667.

138. Kozukue, N. and K. Ogata. 1972. Physiological and chemical studies of chilling injury in pepper fruits. V. The changes of PAL activity in pepper seeds accompanied with chilling injury, and the relationship between the PAL activity in the seeds and the ethylene production by pepper fruits. J. Jap. Soc. Hort. Sci. 4l:322-326.

139. Kuraishi, S. , T. Tezuka, T. Ushijima, and T. Tazaki. 1966. Effect of cytokinins on frost hardiness. Plant \& Cell Physiol. 7:705-706.

140. Kuraoka, T., K. Iwasaki, and T. Ishii. 1977. Effects of $\mathrm{GA}_{3}$ on puffing and levels of $\mathrm{GA}-\mathrm{like}$ substances and $A B A$ in the peel of satsuma mandarin (Citrus unshiu Marc.). J. Amer. Soc. Hort. Sci. $102: 651-654$.

141. Kuraoka, T. K. Iwasaki, and T. Ishii. 1979. Effects of $\mathrm{GA}_{3}$ and ethephon on the level of $\mathrm{ABA}$ and peroxidase activity in the peel of satsuma mandarin (Citrus unshiu Marc.). J. Japan Soc. Hort. Sci. $4 \overline{7: 437-4} 42$. 
142. Lavee, S. 1973. Dormancy and bud break in warm climates; considerations of growth regulator involvement. Acta Hort. 34:225-234.

143. Lenton, J.R., V.M. Perry, and P.F. Saunders. 1971. The identification and quantitative analysis of abscisic acid in plant extracts by gas-liquid chromatography. Planta (Berl.) 96:271-280.

144. Lenton, J.R., V.M. Perry, and P.F. Saunders. 1972. Endogenous abscisic acid in relation to photoperiodically induced bud dormancy. Planta $106: 13-22$.

145. Leshem, Y.Y., S. Grossman, A. Frimer, and J. Ziv. 1979. Endogenous lipoxygenase control and lipidassociated free radical scavenging as modes of cytokinin action in plant senescence retardation. p. 193-198. In L.O. Appeiquist and C. Liljenberg (eds.) Advances in the biochemistry and physiology of plant lipids. Elsevier/North-Holland Biomedical Press, New York, N.Y.

146. Levitt, J. 1972. Comparative stress responses. p. 544-568. In J. Levitt (ed.) Responses of plants to environmental stresses. Academic Press, New York, N.Y.

147. Levitt, J. 1980. Responses of plants to environmental stresses, 2nd ed. Academic Press, New York, N.Y.

148. Lewis, D.A. 1956. Physiological studies of tomato fruits injured by holding at chilling temperatures. Ph.D. Dissertation, Univ. of California, Davis, CA. $153 \mathrm{p}$.

149. Lewis, L.N., R.A. Khalifah, and C.w. Coggins, Jr. 1965. Seasonal changes in citrus auxin and 2 auxin antagonists. Plant Physiol. 40:500-505.

150. Lipton, w.J. 1978. Chilling injury of 'Honey Dew' muskmelons: Symptors and relation to degree of ripeness at harvest. HortScience 13:45-46.

151. Lipton, W.J. and y. Aharoni. 1979. Chilling injury and ripening of 'Honey Dew' muskmelons stored at $2.5^{\circ}$ or $5^{\circ} \mathrm{C}$ after ethylene treatment at $20^{\circ} \mathrm{C}$. J. Amer. Soc. Hort. Sci. 104:327-330.

152. Lipton, W.J., Y. Aharoni, and E. Elliston. 1979. Rates of $\mathrm{CO}_{2}$ and ethylene production and ripening of 'Honey Dew' muskmelons at a chilling temperature after pretreatment with ethylene. J. Amer. soc. Hort. Sci. 104:846-849. 
153. Little, C.H.A., J.K. Heald, and G. Browning. 1978. Identification and measurement of indoleacetic and abscisic acids in the cambial region of Picea sitchesis (Bong.) Carr. by combined gas chromatography-mass spectrometry. Planta 139: 133-138.

154. Luke, N., C. Chin, and P. Eck. 1977. Dialysis extraction of gibberellin-like substances from cranberry tissue. HortScience 12:245-246.

155. Lutz, J.N. and R.E. Hardenburg. 1968. The commercial storage of fruits, vegetables, and florist and nursery stocks. U.S. Dept. Agr., Agr. Handbk. 66 .

156. Lyons, J.M. 1973. Chilling injury in plants. Ann. Rev. Plant Physiol. 24:445-466.

157. Lyons, J.D., D. Graham, and J.K. Raison. 1980. Low temperature stress in crop plants: The role of the membrane. Academic Press, New York, N.Y.

158. Mann, J.D. and E.G. Jaworski. 1970. Minimizing loss of indoleacetic acid during purification of plant extracts. Planta (Berl.) 92:285-291.

159. Mansfield, T.A., A.R. Wellburn, and T.J.S. Moreira. 1978. The role of abscisic acid and franesol in the alleviation of water stress. Phil. Trans. R. Soc. Lond. B. $284: 471-482$.

160. Martin, G.C. and C. Nishijima. 1977. Contaminants in solvents and chromatographic materials. HortScience $12: 212-216$.

161. Martin, G.C., C. Nishijima, and J.M. Labavitch. 1980. Analysis of indoleacetic acid by the nitrogenphosphorus detector gas chromatograph. J. Amer. Soc. Hort. Sci. 105:46-50.

162. Martin, W.R., R.G. Hilgeman, and J.G. Smith. 1940. Grapefruit storage studies in Arizona. Proc. Amer. Soc. Hort. Sci. 37:529-534.

163. McColloch, L.P. 1962. Chilling injury and alternaria rot of beil peppers. U.S. Dept. Agr., Mkt. Res. Rept. $536.16 \mathrm{p}$.

164. McColloch, L.P., H.T. Cook, and W.R. Wright. 1968. Market diseases of tomatoes, peppers, and eggplants. U.S. Dept. Agr., Agr. Handbk. 28. 
165. McCornack, A.A. 1976. Chilling injury of 'Marsh' grapefruit as influenced by diphenyl pads. Proc. Fla. State Hort. Soc. 89:200-202.

166. McDaniel, R.G. and B.B. Taylor. 1976. AMP treatments improve emergence under cold stress. p. 9. In Cotton. College of Agr. Rept. Agr. Expt. Sta., Univ. of Arizona, Tucson. Series P-37.

167. MCGlasson, W.B., N.L. Wade, and I Adato. 1978. Phytohormones and fruit ripening. p. 447-493. In D.S. Letham, P.B. Goodwin, and T.J.V. Higgins (eds.) Phytohormones and related compounds: A comprehensive treatise. Vol. II. Elsevier/North-Holland Biomedical Press, New York, N.Y.

168. Merritt, R.H., W.C. Stiles, A.V. Havens, and L.A. Mitterling. 1961. Effects of preharvest air temperatures on storage scald of 'Stayman' apples. proc. Amer. Soc. Hort. Sci. 78:24-34.

169. Mielke, E.A. and F.G. Dennis, Jr. 1975. Hormonal control of flower bud dormancy in sour cherry (Prunus cerasus L.). II. Levels of abscisic acid and its water soluble complex. J. Amer. Soc. Hort. Sci. 100:287-290.

170. Milborrow, B.V. 1974. The chemistry and physiology of abscisic acid. Ann. Rev. Plant physiol. 25:259-307.

171. Milborrow, B.V. and R. Mallaby. 1975. Occurrence of methyl $(+)$-abscisate as an artifact of extraction. J. Expt. Bot. 26:741-748.

172. Miller, E.V. 1946. The physiology of citrus fruits in storage. Bot. Rev. 12:393-423.

173. Mills, V.M. and G.W. Todd. 1973. Effects of water stress on the indoleacetic acid oxidase activity in wheat leaves. Plant Physiol. 51:1145-1146.

174. Mitchel1, J.W. and G.A. Livingston. 1968. Methods of studying plant hormones and growth-regulating substances. U.S. Dept. Agr., Agr. Handbk. 336.

175. Molisch, H. 1886. Das Erfrieren von Pflanzen bei Temperatureren über dem Eispunkt. Sitzber. Kaiserlichen Akad. Viss. Wien. Math. Naturwiss. Kl. 105:1-14. (Quoted in J.M. Lyons. 1973. Chilling injury in plants. Ann. Rev. Plant physiol. 24:445-466.) 
176. Monselise, S.P., R. Goren, and J. Costo. 1967. Hormoneinhibitor balance of some citrus tissues. Israel J. Agr. Res. 17:35-45.

177. Monselise, S.P. and R. Goren. 1978. The role of internal factors and exogenous control in flowering, peel growth, and abscission in citrus. Hortscience $13: 134-139$.

178. Morris, L.L. 1953. Temperature in relation to the ripening behavior of tomato fruits. Proc. Conf. Transport. Perishables, Univ. of California, Davis (Feb. 5-7, 1953), 141-146.

179. Morris, L.L. 1954. Field and transit chilling of fallgrown tomatoes. Proc. Conf. Transport. Perishables, Univ. of California, Davis, CA.. (April 26-28, 1954). p. 101-105.

180. Morris, L.L. and H. Platenius. 1938. Low temperature injury to certain vegetables after harvest. Proc. Amer. Soc. Hort. Sci. 36:609-613.

181. Morris, R.O. and J.B. Zaerr. 1978. 4-Bromophenacyl esters of gibberellins, useful derivatives for high performance liquid chromatography. Analytical Letters $\mathrm{All}(1): 73-83$.

182. Naumann, W.D. and M. Sachs. 1973. Variations in abscisic acid content of strawberry plants during winter-time in Israel. Proc. 19th Int. Hort. Congress, Poland. p. 49 .

183. Nelson, R. 1933. Some storage and transportational. diseases of citrus fruits apparently due to suboxidation. J. Agr. Res. 46:695-713.

184. Nitsch, U.P. 1963. The mediation of climactic effects through endogenous regulating substances. p. 175-193. In L.T. Evans (ed.) Environmental control of plant growth. Academic Press, New York, N.Y.

185. Nowak, J. and G.N. Brown. 1979. Free and bound gibberellin activities and ent-kaurene synthesis during induction of cold hardiness in black locust seedlings. Physiol. Plant. 45:11-16.

186. Olsen, K.L. and G.C. Martin. 1980. Influence of apple bloom data on maturity and storage quality of 'Starking Delicious' apples. J. Amer. Soc. Hort. Sci. 105:183-186. 
187. Palmer, J.K. 1971. The banana. p. 65-105. In A.C. Hulme (ed.) The biochemistry of fruits and their products. Academic Press, New York, N.Y.

188. Pantastico, E.B. 1968. Physiological disorders of tropical and subtropical fruits with particular reference to chilling injury, oleocellosis, and stylar-end breakdown. Ph.D. Dissertation, Univ. of Florida, Gainesville, FL. 148 p.

189. Pantastico, E.B., A.K. Mattoo, T. Murata, and K. Ogata. 1975. Chilling injury. p. 339-362. In E.B.

Pantastico (ed.) Postharvest physiology, handling and utilization of tropical and subtropical fruits and vegetables. AVI Publ. Co., Westport, CT.

190. Pellisier, M., N.L. Lacasse, and H. Cole, Jr. 1972. Effectiveness of benzimidazole, benomyl and thiabendazole in reducing ozone injury to pinto beans. Phytopathology 62:580-582.

191. Pengelly, W. and F. Meins. 1977. A specific radioimmunoassay for nanogram quantities of the auxin indole-3-acetic acid. Planta 136:173-180.

192. Perry, T.O. and H. Hellmers. 1973. Effects of abscisic acid on growth and dormancy of two races of red maple. Bot. Gaz. 134:283-289.

193. Pieniazek, S.Z., E.P. Christopher, and L.A. McElroy. 1946. Further data on the control of storage scald. of apples by means of carbon dioxide. Proc. Amer. Soc. Hort. Sci. $48: 81-88$.

194. Pool, R.M., L.E. Powell. 1972. The use of pellicular ion-exchange resins to separate cytokinins by highpressure liquid chromatography. Hortscience $7: 330$. (Abst.)

195. Powell, L.E. 1972. The evolution of plant hormone analysis. Hortscience $7: 236-238$.

196. Powell, L.E. 1976. Effect of photoperiod on endogenous abscisic acid in Malus and Betula. Hortscience $11: 498-499$.

197. Pratt, H.K. and J.B. Biale. 1944. Relation of the production of an active emanation to respiration in the avocado fruit. Plant Physiol. 19:519-528. 
198. Purvis, A.C., K. Kawada, and W. Grierson. 1979. Relationship between midseason resistance to chilling injury and reducing sugar level in grapefruit peel. Hortscience 14:227-229.

199. Ramsey, H.J. 1915. Handling and shipping citrus fruits in the Gulf States. U.S. Dept. Agr. Farmer's Bul: 696 .

200. Rasmussen, E.J. 1937. Effect of delay in storage temperature on keeping qualities of apples. New Hampshire Expt. Sta. Tech. Bul. 67.

201. Rasmussen, G.K. 1973. The effect of growth regulators on degreening and regreening of citrus fruit. Acta Hort. 34:473-478.

202. Rasmussen, G.K. 1975. Cellulase activity, endogenous abscisic acid, and ethylene in four citrus cultivars during maturation. plant Physiol. 56: 765-767.

203. Rasmussen, O.S. 1976. Water stress in plants. I. Abscisic acid level in tomato leaves after a long period of wilting. Physiol. Plant. 36:208-212.

204. Reda, F., P. Larsen, and O.S. Rasmussen. 1978. Levels of growth regulating substances during vernalization of winter wheat. Physiol. Plant. 42:109-113.

205. Reed, W. and G.C. Martin. 1976. Identification of gibberellin $A_{29}$ and evidence for abscisic acid in extracts from fruits of immature French prune (Prunus domestica L.). J. Amer. Soc. Hort. Sci. 101:527-531.

206. Reid, D.M., R.P. Pharis, and D.W.A. Roberts. 1974. Effects of temperature regimens on the gibberellin content of winter wheat cv. Kharkov. Physiol. Plant. $30: 53-57$.

207. Rikin, A., D. Atsmon, and C. Gitler. 1979. Chilling injury in cotton (Gossypium hirsutum L.) : Prevention by abscisic acid. plant\& Cell physiol. $20: 1537-1546$.

208.Rikin, A., D. Atsmon, and C. Gitler. 1979. Hormonal regulation of tissue response to chilling. Abst. xth Int. Conference Plant Growth Substances. Madison, WI. p. 31. Abst. No. 703. 
209. Rikin, A., A. Blumenfield, and A.E. Richmond. 1976. Chilling resistance as affected by stressing environments and abscisic acid. Bot. Gaz. $137: 307-312$.

210. Riken, A. and A.E. Richmond. 1976. Amelioration of chilling injuries in cucumber seedlings by abscisic acid. Physiol. Plant. 38:95-97.

211. Riken, A. and A.E. Richmond. 1979. Factors affecting leakage from cucumber cotyledons during chilling stress. Plant Sci. Letters 14:263-268.

212. Rikin, A., M. Waldman, A.E. Richmond, and A. Dovrat. 1974. Hormonal regulation of morphogenesis and cold-resistance. I. Modifications by abscisic acid and by gibberellic acid in alfalfa (Medicago sativa) seedlings. J. Expt. Bot. 26:175-183.

213. Rosa, J.T. 1926. Ripening and storage of tomatoes. Proc. Amer. Soc. Hort. Sci. 23:233-242.

214. Rose, D.H., H.T. Cook, and W.H. Redit. 1951. Harvesting, handing, and transportation of citrus fruits. U.S. Dept. Agr. Bib. Bul. 13.

215. Rudnicki, R., J. Machnik, and J. Pieniazek. 1968. Accumulation of abscisic acid during ripening of pears ('Clapp's Favourite') in various storage conditions. Bul. Acad. Pol. Sci. Ser. Sci. Biol. $16: 509-512$.

216. Rudnicki, R. and J. Pieniazek. 1970. The changes in concentration of abscisic acid (ABA) in developing and ripe apple fruits. Bul. Acad. Pol. Sci. Ser. Sci. Biol. 18:577-580.

217. Rudnicki, R. and J. Pieniazek. 1971. Free and bound abscisic acid in developing and ripe stawberries. Bul. Acad. Pol. Sci. Ser. Sci. Biol. 19:421-423.

218. Rygg, G.L. and E.M. Harvey. 1938. Behavior of pectic substances and naringin in grapefruit in the field and storage. Plant physiol. 13:571-586.

219. Sacher, J.A. 1973. Senescence and postharvest physiology. Ann. Rev. Plant Physiol. 24:197-224.

220. St. John, J.B. and M.N. Christiansen. 1976. Inhibition of linolenic acid synthesis and modification of chilling resistance in cotton seedlings. Plant Physiol. 57:257-259. 
221. Santarius, K.A. 1973. The protective effect of sugars on chloroplast membranes during temperature and water stress and its relationship to frost, desiccation, and heat resistance. Planta 113:105-114.

222. Saunders, P. 1978. Phytohormones and bud dormancy. p. 423-445. In D.S. Letham, P.B. Goodwin, and T.J.V. Higgins (eds.) Phytohormones and related compounds: A comprehensive treatise. Vol. II. Elsevier/North-Holland Biomedical Press, New York, N.Y.

223. Schiffmann-Nadel, M., E. Chalutz, J. Waks, and M. Dagan. 1975. Reduction of chilling injury in grapefruit by thiabendazole and benomyl during long-terin storage. J. Amer. Soc. Hort. Sci. $100: 270-272$.

224. Schiffmann-Nađel, M., E. Chalutz, J. Waks, and F.S. Lattar. 1972. Reduction of pitting of grapefruit by thiabendazole during long-term cold storage. HortScience 7:394-395.

225. Schiffmann-Nadel, M., F.S. Lattar, and J. Waks. 1971. The response of grapefruit to differnt storage temperatures. J. Amer. Soc. Hort. Sci. 96:87-90.

226. Sellchop, J.P.F. and S.C. Salmon. 1928. The influence of chilling above the freezing point on certain crop plants. J. Agr. Res. 37:315-338.

227. Sengupta, S.K., M.N. Rogers, and E.J. Lorah. 1974. Effects of photoperiod and ethephon treatment on abscisic acid levels in Chrysanthemum morifolium Ramat. J. Amer. Soc. Hort. Sci. 99:41 $\overline{6-420 .}$

228. Setter, T.L., W.A. Brun, and M.L. Brenner. 1980. Effect of obstructed translocation on leaf abscisic acid, and associated stomatal closure and photosynthesis decline. Plant Physiol. 65:1111-1115.

229. Shirakawa, T., R.R. Dedolph, and D.P. Watson. 1964. $\mathrm{N}-6$-benzyladenine effects on chilling injury, respiration, and keeping quality of Anthurium andraeanum. Proc. Amer. Soc. Hort. Sci. 85:642-646.

230. Sinclair, W.B. 1961. The orange: Its biochemistry and physiology. Univ. of California, Div. of Agr. Sci. Berkeley, CA.

231. Sinclair, ..B. 1972. The grapefruit: Its composition, physiology, and products. Univ. of California, Div. of Agr. Sci., Berkeley, CA. 
232. Smith, C.W. and E.L. Williams. 1979. Amelioration of chilling injury in Maranta leuconeura and Scindapsus pictus by preconditioning. HortScience $14: 439$. (Abst.)

233. Smock, R.M. 1980. Stop apple scald! Amer. Fruit Grower $100(2): 23$.

234. Smolenska, G. and P.J.C. Kuiper. 1977. Effect of low temperature upon lipid and fatty acid composition of roots and leaves of winter rape plants. Physiol. Plant. 41:29-35.

235. Smoot, J.J., L.G. Houck, and H.B. Johnson. 1971. Market' diseases of citrus and other subtropical fruits. U.S. Dept. Agr., Agr. Handbk. 298.

236. Soule, J. and W. Grierson. 1978. Citrus maturity and packinghouse procedures. FRC 4612. Dept. Fruit Crops, Univ. of Florida, Gainesville, FL.

237. Spranger, E. 1941. Das Erfrieren der Pflanzen uber $0^{\circ}$ mit besonderer Berucksichtigung der Warmhauspflanzen. Gartenbauwiss. 16:90-128.

238. Steffens, G.L. 1978. Bioassay techniques for the evaluation of plant hormones and growth regulators. Proc. Plant Growth Regulator Working Group 1978: 45-59.

239. Sterns, C.R., Jr. 1942. Color break studies. Fla. Agr. Expt. Sta. Ann. Rept. 156-157.

240. Steward, J.M. 1968. Some effects of chilling on respiration, photosynthesis and nucleotide composition of cotton seedlings. Ph.D. Dissertation, Oklahoma State Univ., Stillwater, OK. $81 \mathrm{p}$.

241. Steward, J.M. and G. Guinn. 1969. Chilling injury and changes in adenosine triphosphate of cotton seedlings. Plant Physiol. 44:605-608.

242. Stewart, I. and T.A. Whecton. 1971. Effects of ethylene and tempercture on carotenoid pigmentation of citrus peel. Proc. Fla. State Hort. Soc. $84: 264-266$.

243. Sweetser, P.B. 1978. Use of modern forms of chromatography for plant grcwth substance analysis (I). Proc. Plant Growth Regulator Working Group 1978:1-19. 
244. Sweetser, P.B. and D.G. Swartzfager. 1978. Indole-3acetic acid levels of plant tissue as determined by a new high performance liquid chromatographic method. Plant Physiol. 61:254-258.

245. Sweetser, P.B. and A. Vatvars. 1976. High-performance liquid chromatographic analysis of abscisic acid in plant extracts. Anal. Biochem. 71:68-78.

246. Takahashi, N., I. Yamaguchi, T. Kōno, M. Igoshi, K. Hirose, and K. Suzuki. 1975. Characterization of plant growth substances in Citrus unshiu and their change in fruit development. Plant \& Cell Physiol. 16:1101-11ll.

247. Taylor, J.S. and E.B. Dumbroff. 1975. Bud, root, and growth regulator activity in Acer saccharum during the dormant season. Can. J. Bot. $\overline{53: 321-331}$.

248. Thimann, K.V. 1972. The natural plant hormones. p. 3-365. In F.C. Steward (ed.) Plant physiology: A treatise, Vol. VIB. Academic Press, New York, N.Y.

249. Thomas, T.H., J.W. Carrol, F.M.R. Isenberg, A. Pendergrass, and L. Howell. 1975. Separation of cytokinins from Danish cabbage by column chromatography on insoluble polyvinylpyrrolidone. Physiol. Plant. 33:83-86.

250. Thomas, T.H., J.W. Carrol, F.M.R. Isenberg, A. Pendergrass, and L. Howell. 1975. Thin-layer chromatography of cytokinins on a mixed layer of polyvinylpyrrolidone and calcium sulphate. J. Chromato. 103:211-215.

251. Tumanov, I.I. and T.I. Truniva. 1958. The influence of growth processes on the hardening of winter plant tissues. F. Ziol. Rast. 5:108-122.

252. Uota, M. 1952. Temperature studies on the development of anthocyanin in 'McIntosh' apples. Proc. Amer. Soc. Hort. Sci. 59:231-237.

253. Vakis, N.I. 1971. Some physiological and biochemical aspects of the chilling syndrome in tropical and subtropical fruits. Ph.D. Dissertation, Univ. of Florida, Gainesville, FL. 100 p. 
254. Vakis, N., W. Grierson, and J. Soule. 1970. Chilling injury in tropical and subtropical fruits. III. The role of $\mathrm{CO}_{2}$ in suppressing chilling injury of grapefruit and avocados. Proc. Trop. Reg. Amer. Soc. Hort. Sci. 14:89-100.

255. Vakis, N., J. Soule, R.H. Biggs, and W. Grierson. 1970. Biochenical changes in grapefruit and 'Murcott' citrus fruits as related to storage temperature. Proc. Fla. State Hort. Soc. 83:304-310.

256. van der Plank, J.E. 1938. Delayed storage of 'Marsh' grapefruit. Ann. Rept. So. Africa Dept. Agr. and Forest., Low Temp. Res. Lab. (Capetown). 1936-37: 154-158.

257. van der Plank, J.E. 1938. I. The differnt forms of cold injury of 'Marsh' grapefruit and navel oranges; and the modifying effect on them of varying temperatures of storage. II. Some storage blemishes of oranges which are not due to cold injury. Ann. Rept. So. Africa Dept. Agr. and Forest., Low Temp. Res. Lab. (Capetown). 1936-37:159-171.

258. van der Plank, J.E. 1939. Cold storage of grapefruit. I. The effect of position of the tree. II. The effect of the period of storage at $40^{\circ}$ and of the period of delayed storage at $80^{\circ} \mathrm{F}$. Ann. Rept. So. Africa Dept. Agr. and Forest., Low Temp. Res. Lab. (Capetown). 1937-38:145-155.

259. van der Plank, J.E., J.M. Rattray, W.W. Boyes, and D.J.R. de Villiers. 1938. The effect of temperature of storage on 'Marsh' grapefruit. Ann. Rept. So. Africa Dept. Agr. and Forest., Low Temp. Res. Lab. (Capetown). 1936-37:147-150.

260. Van Onckelen, H.A., R. Verbeek-Wyndale, and J.A. de Greef. 1976. Estimation of gibberellins and inhibitors of $\propto$-amylase synthesis in Phaseolus vulgaris $L$. using a modified barley endosperm bioassay. Bul. Soc. Roy. Bot. Belg. 109:335-346.

261. Waldman, M., A. Rikin, A. Dovrat, and A.E. Richmond. 1975. Hormonal regulation of morphogenesis and cold-resistance. J. Expt. Bot. 26:853-859.

262. Wallerstein, I., R. Goren, and S.P. Monselise. 1973. Seasonal changes in gibberellin-like substances of 'Shamouti' orange (Citrus sinensis (L.) Osbeck) trees in relation to ringing. J. Hort. Sci. $48: 75-82$. 
263. Walton, D., W. Dashek, and E. Galson. 1979. A radioimmunoassay for abscisic acid. Planta 146:139-145.

264. Wang, C.Y. and J.E. Baker. 1979. Effects of two free radical scavengers and intermittent warming on chilling injury and polar lipid composition of cucumber and sweet pepper fruits. Plant \& Cell Physiol. 20:243-251.

265. Wang, C.Y., S.Y. Wang, and W.M. Mellenthin. 1972. Identification of abscisic acid in 'Bartlett' pears and its relationship to premature ripening. J. Agr. Food Chem. 20:451-453.

266. Wardlaw, C.W. and E.R. Leonard. 1939. Storage investigations with Trinidad grapefruit, 1938-39. Tropical Agr. (Trinidad) 16:208-215.

267. Wardowski, W.F., L.G. Albrigo, W. Grierson, C.R. Barmore, and T.A. Wheaton. 1975. Chilling injury and decay of grapefruit as affected by thiabendazole, benomy 1 , and $\mathrm{CO}_{2}$. HortScience 10:381-383.

268. Wardowski, W.F., W. Grierson, and G.J. Edwards. 1973. Chilling injury of stored limes and grapefruit as affected by differentially permeable packaging films. HortScience $8: 173-175$.

269. Wardowski, W.F., J. Soule, W. Grierson, and G. Westbrook. 1979. Florida citrus quality tests. Fla. Agr. Expt. Sta. Bul. 188 .

270. Wareing, P.F. and P.F. Saunders. 1971. Hormones and dormancy. Ann. Rev. Plant. Physiol. 21:261-288.

271. Watada, A.E. 1965. Physiological studies with detached fruits of snap bean (Phaseolus vulgaris L.) at chilling and non-chilling temperatures: Ph.D. Dissertation, Univ. of California, Davis, CA. 84 p.

272. Weaver, R.J. 1972. Plant growth substances in agriculture. W.H. Freeman and Co., San Francisco, CA.

273. Weiler, E.W. 1979. Radioimmunoassay for the determination of free and conjugated abscisic acid. Planta $144: 255-263$.

274. Weiler, E.W. 1980. Radioimunoassays for the differential and direct analysis of free and conjugated abscisic acid in plant extracts. Planta 148:262-272. 
275. Weiler, E.W. 1980. Radioimmunoassays for trans-zeatin and related cytokinins. Planta 149:155-162.

276. Wheaton, T.A. 1963. Physiological comparison of plants sensitive and insensitive to chilling temperatures. Ph.D. Dissertation, Univ. of California, Davis, CA. 93 p.

277. Wheaton, T.A. and M.G. Bausher. 1977. Separation and identification of endogenous growth regulators in citrus. Proc. Int. Soc. Citriculture 2:673-676.

278. Wheaton, T.A. and L.L. Morris. 1967. Modification of chiliing sensitivity by temperature conditioning. Proc. Amer. Soc. Hort. Sci. 91:529-533.

279. Wheaton, T.A. and I. Stewart. 1973. Optimum temperature and ethylene concentrations for postharvest development of carotenoid pigments in citrus. J. Amer. Soc. Hort. Sci. $98: 337-340$.

280. Wightman, F. 1978. Modern chromatographic methods for the identification and quantification of plant growth regulators and their application to studies of the changes in hormonal substances in winter wheat during acclimation to cold stress conditions. p. 327-377. In T.K. Scott (ed.) Plant regulation and world agriculture. Plenum Press, New York, N.Y.

281. Wilkinson, B.G. 1966. The effect of orchard factors and weather on the storage life ofapples. Proc. XVII Int. Hort. Congress $1: 248$.

282. Wills, R.B.H. 1973. Metabolism of added gibberellic acid in Malus pumilla in relation to cool storage breakdown. Phytochemistry 12:2607-2608.

283. Wills, R.B.H. and K.J. Scott. 1974. Effect of phorone and other growth regulators on the incidence of storage breakdown in apples. J. Hort. Sci. $49: 199-202$.

284. Wilson, J.M. 1976. The mechanism of chill- and droughthardening of Phaseolus vulgaris leaves. New Phytol. 76:257-270.

285. Wilson, J.M. 1978. Leaf respiration and ATP levels at chiliing temperatures. New Phytol. 80:325-334.

286. Wilson, J.M. 1978. Lipid changes in plants at temperatures inducing chill-hardiness. Pestic. Sci.

$9: 173-183$. 
237. Wilson, J.M. and R.M.M. Crawford. 1974. Leaf fattyacid content in relation to hardening and chilling injury. J. Expt. Bot. 25:121-131.

288. Wiltbank, W.J. and A.H. Krezdorn. 1969. Determination of gibberellins in ovaries and young fruits of navel oranges and their correlation with fruit growth. J. Amer. Soc. Hort. Sci. 94:195-201.

289. Wright, M. 1974. The effect of chilling on ethylene production, membrane permeability and water loss of leaves of Phaseolus vulgaris. Planta (Berl.) $120: 63-69$.

290. Yamaguchi, I., T. Yokota, N. Murofushi, N. Takahashi, and $\mathrm{Y}$. Ogawa. 1975. Isolation of gibberellins $\mathrm{A}_{5}, \mathrm{~A}_{32}, \mathrm{~A}_{32}$ acetonide and $(+)$-abscisic acid from Prunus persica. Agr. Biol. Chem. (Tokyo) 39: 2399-2403.

291. Yelenosky, G. 1978. Cold hardening 'Valencia' orange trees to tolerate $-6.7^{\circ} \mathrm{C}$ without injury. J. Amer. Soc. Hort. Sci. 103:449-452.

292. Yelenosky, G. 1979. Water-stress-induced cold hardening of young citrus trees. J. Amer. Soc. Hort. Sci. $104: 270-273$.

293. Yelenosky, G. and C.I. Guy. 1977. Carbohydrate accumulation in leaves and stems of 'Valencia' orange at progressively colder temperatures. Bot. Gaz. 138:13-17.

294. Young, R.E. and S.K. Lee. 1979. The effect of ethylene on chilling and high temperature injury of avocado fruit. HortScience 14:421. (Abst.)

295. Zeevaart, J.A.D. 1971. Effects of photoperiod on growth rate and endogenous gibberellins in the long-day rosette plant spinach. Plant Physiol. $47: 821-827$.

296. Zeevaart. J.A.D. 1977. Sites of abscisic acid synthesis and metabolism in Ricinus communis L. Plant Physiol. 59:788-79

297. Zelleke, A., G.C. Martin, and J.M. Labavitch. 1980. Detection of cytokinins using a gas chromatograph equipped with a sensitive nitrogen-phosphorus detector. J. Aner. Soc. Hort. Sci. 105:50-53. 
BIOGRAPHICAL SKETCH

Kazuhide Kawada was born at Takamatsu, Kagawa, Japan, on October 5, 1951, as the third son of Yoshio Kawada and Yukie Kawada. His secondary education was completed at Takamatsu Senior High School in 1970. He attended the Faculty of Agriculture, Kagawa University, and received the degree of Bachelor of Agricultural science in 1974. In 1976 he completed the degree of Master of Agricultural Science with the graduate school of the Kagawa University. The following 5 months in 1976 he was a research fellow of the Kagawa University graduate school. He enrolled in the graduate school of the University of Florida in 1977, where he was awarded the degree of Doctor of Philosophy with major in horticultural science (fruit crops) in December 1980 .

He is a member of the International society for Horticultural Science, International Society of Citriculture, International Plant Growth Substances Association, Japanese Society for Horticultural Science, American Society for Horticultural science, Plant Growth Regulator Working Group (U.S.A.), and of the Florida state Horticultural society. 
I certify that I have read this study and that in my opinion it conforms to acceptable standards of scholarly presentation and is fully adequate, in scope and quality, as a dissertation for the degree of Doctor of Philosophy.

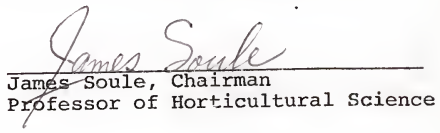

I certify that I have read this study and that in my opinion it conforms to acceptable standards of scholarly presentation and is fully adequate, in scope and quality, as a dissertation for the degree of Doctor of Philosophy.

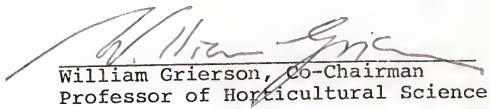

I certify that I have read this study and that in my opinion it conforms to acceptable standards of scholarly presentation and is fully adequate, in scope and quality, as a dissertation for the degree of Doctor of Philosophy.

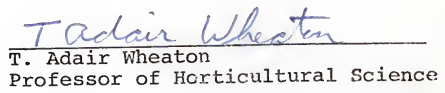

I certify that I have read this study and that in my opinion it conforms to acceptable standards of scholarly presentation and is fully adequate, in scope and quality, as a dissertation for the degree of Doctor of Philosophy.

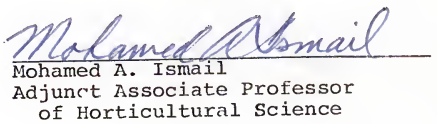


I certify that I have read this study and that in my opinion it conforms to acceptable standards of scholarly presentation and is fully adequate, in scope and quality, as a dissertation for the degree of Doctor of Philosophy.

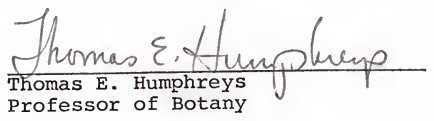

This dissertation was submitted to the Graduate Faculty of the College of Agriculture and to the Graduate Council, and was accepted as partial fulfillment of the requirements for the degree of Doctor of Philosophy

December, 1980

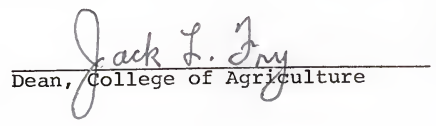

Dean for Graduate Studies and Research 